\title{
\#USGS
}

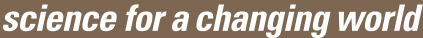

Prepared in cooperation with the Idaho Department of Lands and the Midas Gold Corporation

\section{Occurrence and Transport of Selected Constituents in Streams near the Stibnite Mining Area, Central Idaho, 2012-14}

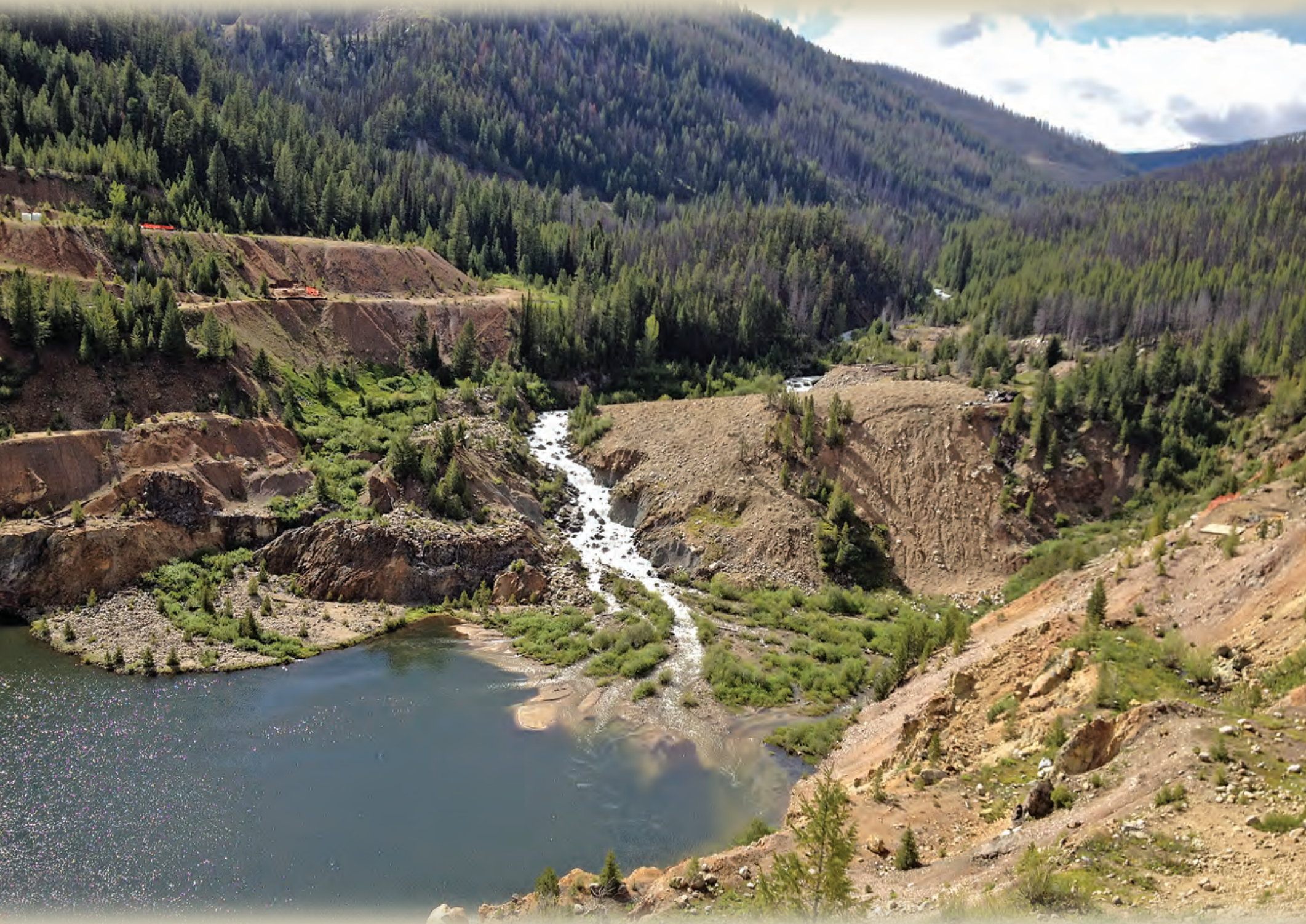

Scientific Investigations Report 2015-5166

U.S. Department of the Interior

U.S. Geological Survey 
Cover: Photograph of Glory Hole near Stibnite, Idaho, June 13, 2012.

Photograph by Alexandra Etheridge, U.S. Geological Survey. 


\section{Occurrence and Transport of Selected Constituents in Streams near the Stibnite Mining Area, Central Idaho, 2012-14}

By Alexandra B. Etheridge

Prepared in cooperation with the Idaho Department of Lands and the

Midas Gold Corporation

Scientific Investigations Report 2015-5166 


\title{
U.S. Department of the Interior SALLY JEWELL, Secretary
}

\section{U.S. Geological Survey \\ Suzette M. Kimball, Acting Director}

\author{
U.S. Geological Survey, Reston, Virginia: 2015
}

For more information on the USGS - the Federal source for science about the Earth, its natural and living resources, natural hazards, and the environment—visit http://www.usgs.gov or call 1-888-ASK-USGS.

For an overview of USGS information products, including maps, imagery, and publications, visit http://www.usgs.gov/pubprod/.

Any use of trade, firm, or product names is for descriptive purposes only and does not imply endorsement by the U.S. Government.

Although this information product, for the most part, is in the public domain, it also may contain copyrighted materials as noted in the text. Permission to reproduce copyrighted items must be secured from the copyright owner.

Suggested citation:

Etheridge, A.B., 2015, Occurrence and transport of selected constituents in streams near the Stibnite mining area, central Idaho, 2012-14: U.S. Geological Survey Scientific Investigations Report 2015-5166, 47 p., http://dx.doi. org/10.3133/20155166.

ISSN 2328-0328 (online) 


\section{Contents}

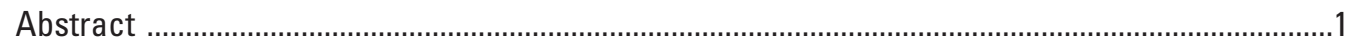

Introduction

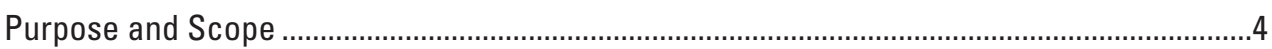

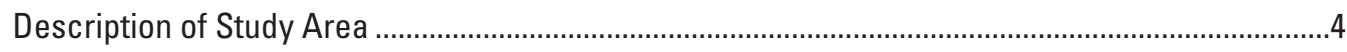

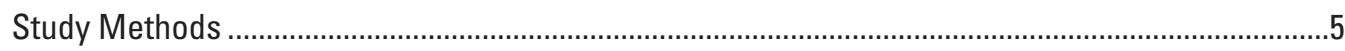

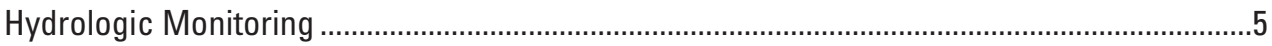

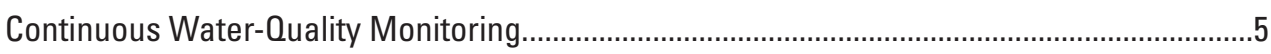

Water-Quality Sampling and Analysis....................................................................................

Data Quality Assurance and Quality Control..............................................................................

Model Development .........................................................................................................

LOADEST Models for Estimating Constituent Loads.....................................................

Surrogate Regression Models for Estimating Constituent Concentrations.......................9

Calculation of Streamflow-Weighted Concentrations using LOADEST Results .......................

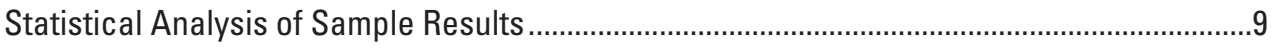

Ambient Water-Quality Criteria ...............................................................................................

Streamflow and Water-Quality Monitoring .........................................................................10

Occurrence, Transport, and Deposition of Selected Constituents................................................14

LOAD ESTimation (LOADEST) Model Results ..........................................................................

Streamflow Variability and Hysteresis in Particulate Constituent Transport ..........................31

Surrogate Regression Modeling of Constituent Concentrations......................................................35

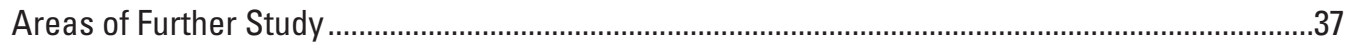

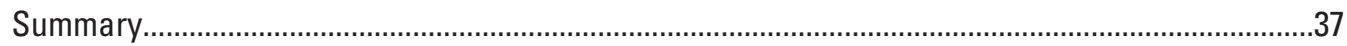

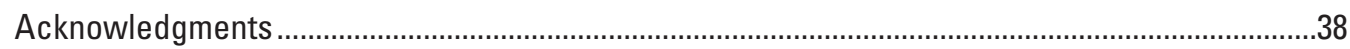

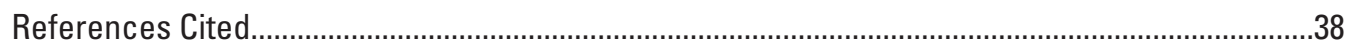

Appendix A. Analysis of Quality-Assurance and Quality-Control Data from

Field Samples in Streams in the Stibnite Mining Area, Central Idaho, and

Laboratory Samples from the National Water-Quality Laboratory, 2012-14 ........................43

Appendix B. Statistical Summary of Constituent Concentrations in Water-Quality

Samples Collected at Streamflow-Gaging Stations in the Stibnite Mining Area,

Central Idaho, 2012-14. 


\section{Figures}

1. Map showing streamflow-gaging stations and water-quality monitoring sites near the Stibnite mining area, central Idaho, 2012-14

2. Hydrograph showing streamflow duration (1928-2014) and measured streamflow at East Fork of South Fork of the Salmon River at Stibnite, central Idaho, 2012-14

3. Hydrographs showing 50th and 90th streamflow percentiles for the periods of record, daily mean streamflow, and timing of water-quality sample collection at East Fork of South Fork of the Salmon River at Stibnite, central Idaho, 2012-14.

4. Boxplot showing total mercury concentrations in five streamflow and water-quality monitoring sites in the Stibnite mining area, central Idaho, 2012-14 .......12

5. Graphs showing temperature exceedance for five streamflow and water-quality monitoring sites in the Stibnite mining area, central Idaho, 2012-14 .

6. Graph showing correlation between streamflow and constituent concentrations for trace elements and suspended sediment in streams in the Stibnite mining area, central Idaho, 2012-14.

7. Pie diagrams showing streamflow and load contributions from discrete reaches as a percentage of total estimated streamflow and loads attributable to streams in the Stibnite mining area, central Idaho, 2012-14.

8. Diagram showing estimated mean annual total arsenic loads in streams in the Stibnite mining area, central Idaho, 2012-14

9. Diagram showing estimated mean annual total antimony loads in streams in the Stibnite mining area, central Idaho, 2012-14

10. Diagram showing estimated mean annual dissolved manganese loads in streams in the Stibnite mining area, central Idaho, 2012-14.....

11. Graphs showing estimated mean annual streamflow-weighted concentrations of arsenic, antimony, and manganese in streams in the Stibnite mining area, central Idaho, 2012-14.

12. Map showing locations of substantial sources of arsenic and antimony identified along Meadow Creek, Stibnite mining area, central Idaho, September 22,2011

13. Diagram showing estimated mean annual suspended sediment loads at monitoring sites in the Stibnite mining area, central Idaho, 2012-14 ...

14. Diagram showing estimated mean annual total aluminum loads at monitoring sites in the Stibnite mining area, central Idaho, 2012-14

15. Diagram showing estimated mean annual dissolved aluminum loads at monitoring sites in the Stibnite mining area, central Idaho, 2012-14.

16. Graphs showing estimated mean annual streamflow-weighted concentrations of aluminum, lead, and suspended sediment at monitoring sites in the Stibnite mining area, central Idaho, 2012-14

17. Graph showing sampled streamflow and total mercury concentrations in Sugar Creek near Stibnite, central Idaho, 2012-14 


\section{Tables}

1. Streamflow-gaging and water-quality monitoring stations near the Stibnite mining area, central Idaho, 2012-14.

2. Exceedances of water-quality criteria in samples collected from five streamflow and water-quality monitoring sites in the Stibnite mining area, central Idaho, 2012-14.

3. Ratio of dissolved to total mean streamflow-weighted concentrations for selected constituents at five streamflow and water-quality monitoring sites in the Stibnite mining area, central Idaho, 2012-14

4. Estimated annual loads of selected trace elements and suspended sediment at five streamflow and water-quality monitoring sites in the Stibnite mining area, central Idaho, 2012-14

5. Estimated streamflow-weighted concentrations of selected constituents at five streamflow and water-quality monitoring sites in the Stibnite mining area, central Idaho, 2012-14

6. Substantial sources of arsenic and antimony identified at selected sites along Meadow Creek, Stibnite mining area, central Idaho, September 22, 2011.

7. Regression coefficients and coefficients of determination (R2) for models used to estimate loads of selected constituents at monitoring sites in the Stibnite mining area, central Idaho, 2012-14.

8. Regression coefficients and model diagnostics for surrogate models used to estimate concentrations of selected constituents at monitoring sites in the Stibnite mining area, central Idaho, 2012-14 


\section{Conversion Factors}

Inch/Pound to International System of Units

\begin{tabular}{|c|c|c|}
\hline Multiply & By & To obtain \\
\hline \multicolumn{3}{|c|}{ Length } \\
\hline inch (in.) & 2.54 & centimeter (cm) \\
\hline inch (in.) & 25.4 & millimeter (mm) \\
\hline foot $(\mathrm{ft})$ & 0.3048 & meter $(\mathrm{m})$ \\
\hline mile (mi) & 1.609 & kilometer (km) \\
\hline \multicolumn{3}{|c|}{ Area } \\
\hline acre & 4,047 & square meter $\left(\mathrm{m}^{2}\right)$ \\
\hline acre & 0.004047 & square kilometer $\left(\mathrm{km}^{2}\right)$ \\
\hline square mile $\left(\mathrm{mi}^{2}\right)$ & 2.590 & square kilometer $\left(\mathrm{km}^{2}\right)$ \\
\hline \multicolumn{3}{|c|}{ Volume } \\
\hline cubic yard $\left(\mathrm{yd}^{3}\right)$ & 0.7646 & cubic meter $\left(\mathrm{m}^{3}\right)$ \\
\hline \multicolumn{3}{|c|}{ Flow rate } \\
\hline cubic foot per second $\left(\mathrm{ft}^{3} / \mathrm{s}\right)$ & 0.02832 & cubic meter per second $\left(\mathrm{m}^{3} / \mathrm{s}\right)$ \\
\hline \multicolumn{3}{|c|}{ Mass } \\
\hline pound per day (lb/d) & 0.4536 & kilogram per day (kg/d) \\
\hline pound per year (lb/yr) & 0.4536 & kilogram per year (kg/yr) \\
\hline ton per day (ton/d) & 0.9072 & metric ton per day \\
\hline ton per year (ton/yr) & 0.9072 & metric ton per year \\
\hline
\end{tabular}

International System of Units to Inch/Pound

\begin{tabular}{lcl}
\hline \multicolumn{1}{c}{ Multiply } & By & \multicolumn{1}{c}{ To obtain } \\
\hline millimeter (mm) & Length & \\
meter (m) & 0.03937 & inch (in.) \\
meter (m) & 3.281 & foot (ft) \\
\hline & 1.094 & yard (yd) \\
\hline milliliter (mL) & Volume & \\
liter (L) & 0.033814 & ounce, fluid (fl. oz) \\
\hline
\end{tabular}

Temperature in degrees Celsius $\left({ }^{\circ} \mathrm{C}\right)$ may be converted to degrees Fahrenheit $\left({ }^{\circ} \mathrm{F}\right)$ as follows:

${ }^{\circ} \mathrm{F}=\left(1.8 x^{\circ} \mathrm{C}\right)+32$.

Concentrations of chemical constituents in water are given either in milligrams per liter (mg/L) or micrograms per liter $(\mu \mathrm{g} / \mathrm{L})$. 


\section{Datums}

Vertical coordinate information is referenced to the North American Vertical Datum of 1988 (NAVD 88).

Horizontal coordinate information is referenced to the North American Datum of 1983 (NAD 83).

Elevation, as used in this report, refers to feet above NAVD 88.

\section{Abbreviations}

$\begin{array}{ll}\text { AWOC } & \text { ambient water-quality criteria } \\ \text { BFI } & \text { base-flow index } \\ \text { CVO } & \text { Cascades Volcano Observatory } \\ \text { EFSFSR } & \text { East Fork of South Fork of the Salmon River } \\ \text { EPA } & \text { U.S. Environmental Protection Agency } \\ \text { FWC } & \text { streamflow-weighted concentration } \\ \text { IDEO } & \text { Idaho Department of Environmental Quality } \\ \text { IBSP } & \text { Inorganic Blind Sample Project } \\ \text { IDEO } & \text { Idaho Department of Environmental Quality } \\ \text { LOADEST } & \text { LOAD ESTimation program } \\ \text { LRL } & \text { laboratory reporting level } \\ \text { LT-MDL } & \text { long-term method detection level } \\ \text { MDAT } & \text { maximum daily average water temperature criterion for cold-water aquatic life } \\ \text { MDAT-SS } & \text { maximum daily average water temperature criterion for salmonid spawning } \\ \text { MDMT } & \text { maximum daily maximum water temperature (criterion for salmonid spawning) } \\ \text { MWMT } & \text { maximum weekly maximum water temperature criterion for bull trout habitat } \\ \text { MGI } & \text { Midas Gold, Inc. } \\ \text { MLE } & \text { maximum likelihood estimation method } \\ \text { NWIS } & \text { National Water Information System } \\ \text { NWOL } & \text { National Water Quality Laboratory } \\ \text { OA/QC } & \text { quality-assurance/quality-control } \\ \text { OC } & \text { quality-control } \\ \text { R } & \text { coefficient of determination } \\ \text { RMSE } & \text { root mean square error } \\ \text { RPD } & \text { relative percent difference } \\ \text { SVT } & \text { streamflow variability term } \\ \text { USFS } & \text { U.S. Forest Service } \\ \text { USGS } & \text { U.S. Geological Survey } \\ & \end{array}$





\title{
Occurrence and Transport of Selected Constituents in Streams near the Stibnite Mining Area, Central Idaho, 2012-14
}

\author{
By Alexandra B. Etheridge
}

\section{Abstract}

Mining of stibnite (antimony sulfide), tungsten, gold, silver, and mercury near the town of Stibnite in central Idaho has left a legacy of trace element contamination in local streams. Water-quality and streamflow monitoring data from a network of five streamflow-gaging stations were used to estimate trace-element and suspended-sediment loads and flow-weighted concentrations in the Stibnite mining area between 2012 and 2014. Measured concentrations of arsenic exceeded human health-based water-quality criteria at each streamflow-gaging station, except for Meadow Creek (site 2), which was selected to represent background conditions in the study area. Measured concentrations of antimony exceeded human health-based water-quality criteria at sites 3 , 4, and 5 .

Regression models developed using the U.S. Geological Survey LOAD ESTimation (LOADEST) program showed that concentrated sources of arsenic and antimony are present in specific reaches along Meadow Creek and the East Fork of South Fork of the Salmon River (EFSFSR) between the EFSFSR at Stibnite (site 3) and the EFSFSR above Sugar Creek (site 4). Eighty percent of the arsenic and antimony loads were attributable to discrete reaches that accounted for 25 percent of the total streamflow in the study area. Streamflow was negatively correlated with arsenic and antimony concentrations, indicating groundwater sources. Continuously monitored specific conductance, alone or combined with continuously computed streamflow, was more significant than streamflow alone as a surrogate measure of dissolved arsenic and antimony concentrations. Surrogate regression models (with coefficients of determination ranging from 0.96 to 0.65 ) can be used to estimate arsenic and antimony concentrations in real time at all five streamflowgaging stations.

LOADEST model simulation results indicated hysteresis in transport of suspended sediment and sediment-associated constituents. Predictor variables that account for streamflow variability reduced model bias and root mean square error when included in regression models used to estimate concentrations and loads of suspended sediment, total aluminum, total lead, and total mercury.
Ninety-eight percent of the estimated total mercury load transported downstream of the study area is attributable to Sugar Creek. A maximum concentration of 26 micrograms per liter was measured in Sugar Creek during May 2013 when snowmelt runoff occurred during a single peak in the hydrograph. Monitoring and modeling results indicate sediment and sediment-associated constituent concentrations and loads increase along Meadow Creek, likely because of the inflow of the East Fork of Meadow Creek, and decrease between sites 3 and 4 because the Glory Hole is trapping sediments. Sugar Creek (site 5) accounted for most of the sediment and sedimentassociated constituent loading leaving the study area because loads from the East Fork of Meadow Creek remained trapped in the Glory Hole. Additionally, total mercury was detected at all five streamflow-gaging stations, and sampled mercury concentrations exceeded Idaho ambient water-quality criteria at all five streamflow-gaging stations.

\section{Introduction}

The Stibnite mining area (study area) is in the Boise and Payette National Forests along the East Fork of South Fork of the Salmon River (EFSFSR), 14 mi southeast of Yellow Pine, Idaho (fig. 1). Deposits of gold, silver, mercury, antimony, iron, arsenic, and tungsten occur in the study area. In 2009, Midas Gold, Inc. (MGI) began mineral exploration activities as part of the Golden Meadows Exploration Project to better define the potential of mineral deposits in the area. The exploration project defined a need to evaluate existing water-quality conditions in the study area and to identify potential source areas to target further reclamation efforts to be completed prior to or incorporated into plans for renewed mining activity. In cooperation with the Idaho Department of Lands and MGI, the U.S. Geological Survey (USGS) maintains and collects water-quality samples at five streamflow-gaging and waterquality monitoring -stations (herein referred to as monitoring sites) in the study area (fig. 1, table 1). The monitoring site at the EFSFSR at Stibnite, (site 3, table 1) was installed in 1928 and operated intermittently. 


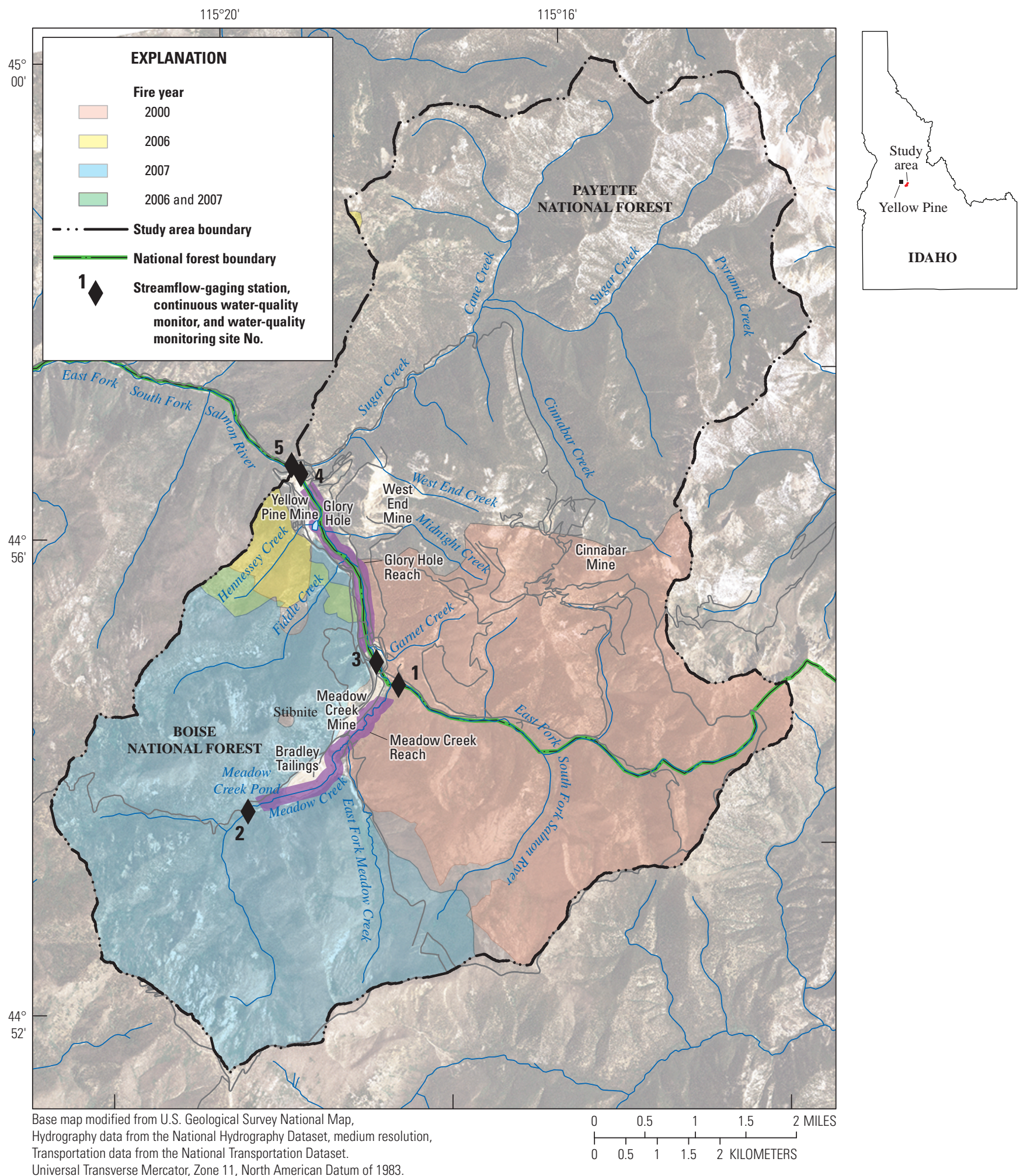

Figure 1. Streamflow-gaging stations and water-quality monitoring sites near the Stibnite mining area, central Idaho, 2012-14. 
Table 1. Streamflow-gaging and water-quality monitoring stations near the Stibnite mining area, central Idaho, 2012-14.

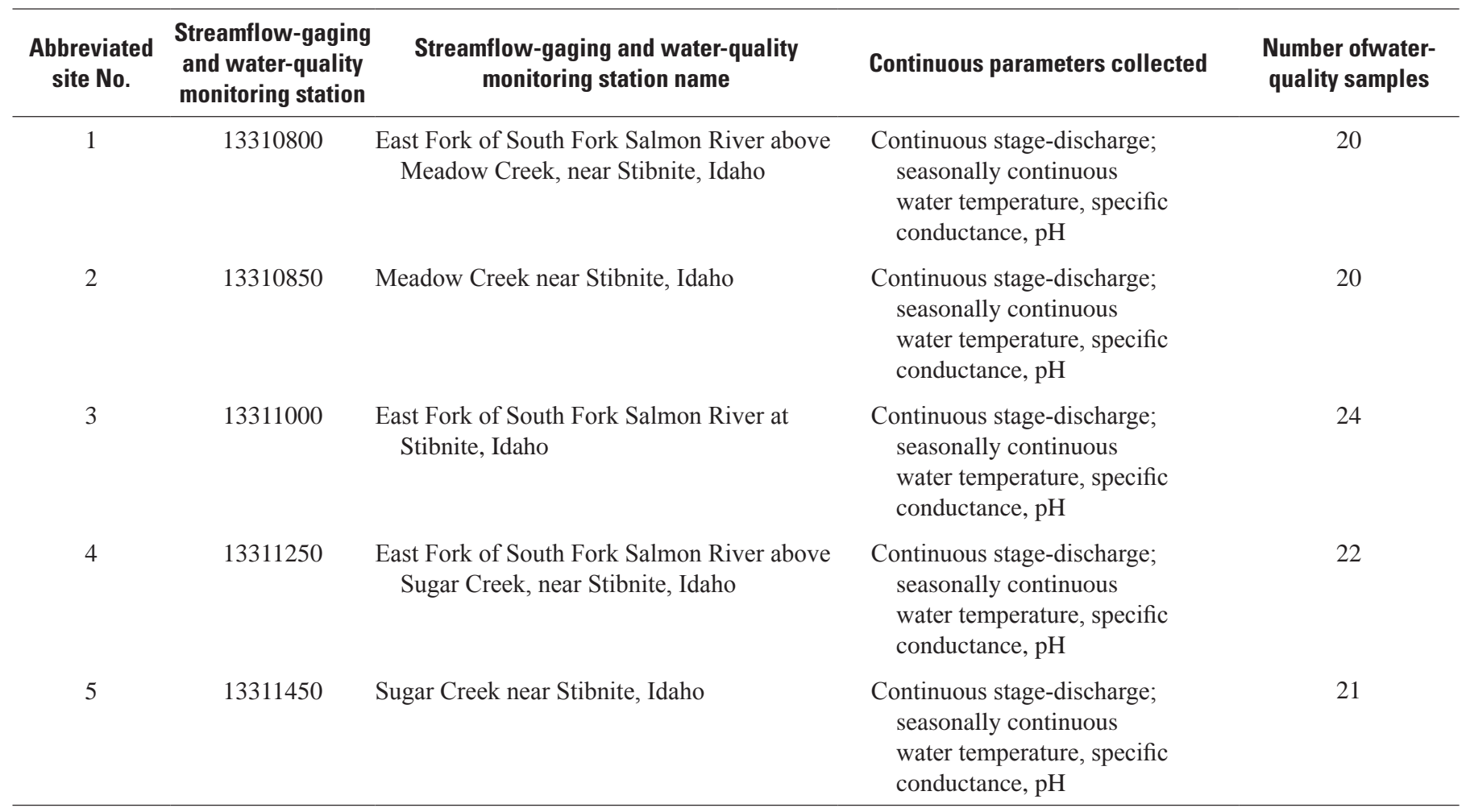

During October 2010 the site was reinstated on a continuous basis. The remaining monitoring sites were installed in September 2011 to support the analysis of trace element occurrence and transport in surface water. This report summarizes findings from hydrologic and water-quality monitoring in the network of five monitoring sites in the Stibnite mining area during water years ${ }^{1} 2012-14$.

Gold, antimony, mercury, and tungsten have been mined and processed in the study area since the early 1900s. During World War II, the Stibnite mining area produced 98 percent of the antimony and 60 percent of the tungsten for the Allied war effort. Mining operations took place at Meadow Creek Mine in the Meadow Creek valley between 1919 and 1938; at Yellow Pine Mine in the area surrounding the Glory Hole (a pit lake) between 1937 and 1952; and at West End Mine in areas near

\footnotetext{
${ }^{1}$ A water year is the period from October 1 of any given year to September 30 of the following year. Water year is used almost exclusively throughout this report. To reduce confusion between calendar years and water years, all reference to years and periods in this report is to water years unless specifically referred to as calendar year.
}

West End Creek and Garnet Creek between 1982 and 1999 (fig. 1). Cinnabar Mine was operated intermittently between 1902 and 1966 in the Cinnabar Creek drainage, which is a tributary to Sugar Creek (fig. 1).

Historical mining-related activities altered stream configuration and habitat in the study area. Mill tailings, known as the Bradley tailings, were disposed in impoundments covering 100 acres of the Meadow Creek valley floor during active mining periods. The Meadow Creek stream channel was diverted around tailings and reconstructed several times to mitigate effects on water-quality from tailings. A dam constructed for mining operations in the East Fork of Meadow Creek failed in 1965, which resulted in tailings and debris deposits downstream. Waste rock dumps were generated upstream and downstream of the Glory Hole, and the EFSFSR was diverted around the Glory Hole as it was mined prior to 1955. After 1955, the Glory Hole was allowed to fill with water and remains part of the EFSFSR channel to date. An estimated 3,000 $\mathrm{yd}^{3}$ of mercury-laden tailings deposited near the Cinnabar Mine on Cinnabar Creek act as a substantial source of mercury in Cinnabar and Sugar Creeks (Trainor, 2003). 
Occurrence and Transport of Selected Constituents in Streams near the Stibnite Mining Area, Central Idaho, 2012-14

Mining-related activities also have affected surface-water quality in the study area. Water-quality monitoring efforts historically preceded periods of renewed mining exploration and followed the completion of various reclamation efforts. A water-quality trend study conducted from 1979 to 1985 showed large increases in turbidity and concentrations of arsenic, antimony, and iron after a renewed period of mining activity in 1982 (Klahr, 1987). Prior investigations monitoring water quality report concentrations of arsenic, free cyanide, lead, mercury, silver, and zinc exceeding chronic freshwater ambient water-quality criteria (AWQC) established for the protection of aquatic organisms in the study area (Trainor, 1993; URS Corporation, 2000).

Federal agencies implemented remediation efforts in mining-affected areas in the late 1990s. The U.S. Environmental Protection Agency (EPA) oversaw a reconstruction of the upper Meadow Creek stream channel that was completed in 1998 (URS Corporation, 2000). The U.S. Forest Service (USFS) reconstructed 4,300 ft of the lower Meadow Creek channel in 2005. The USFS and the EPA capped or removed mercury-contaminated tailings in the Cinnabar Mine area in 2003, and the EPA has shown renewed interest in remediating the Cinnabar Mine area.

The Federal Water Pollution Control Act (the "Clean Water Act”, 33 U.S.C §§1251-1387; see http://www.epa.gov/ oecaagct/lcwa.html) requires states to evaluate surface-water quality and periodically update a list of water bodies where beneficial uses are impaired as a result of poor water quality (the 303[d] list). The Idaho Department of Environmental Quality (IDEQ) determined that beneficial uses in the EFSFSR and Sugar Creek included cold-water salmonid spawning and primary-contact recreation. Additional beneficial uses in the EFSFSR include drinking-water supply for the town of Yellow Pine, and "special-resource water," a classification indicating the need for intensive protection to preserve unique characteristics (Idaho Department of Environmental Quality, 2002). Streams in the study area are critical habitat for Chinook salmon (O ncorhynchus tshawytscha), steelhead (O ncorhynchus mykiss), bull trout (Salvelinus confluentus), and westslope cutthroat trout (O ncorhynchus clarki lewisi), which are all threatened, endangered, or sensitive species (Idaho Department of Environmental Quality, 2002). The IDEQ listed the EFSFSR as impaired for contamination of metals and sediment in 1998, but removed the EFSFSR from the 303(d) list in 2002 (Idaho Department of Environmental Quality, 2002). In 2012, IDEQ listed the EFSFSR and Sugar Creek as water-quality impaired because of concentrations of arsenic and antimony that exceed human health criteria (Idaho Department of Environmental Quality, 2014). IDEQ also listed Sugar Creek as water-quality impaired because of concentrations of mercury that exceed the Idaho chronic AWQC.

\section{Purpose and Scope}

This report summarizes findings from a five-station water-quality and hydrologic monitoring network in the Stibnite mining area during 2012-14. Findings will provide a baseline understanding of surface-water-quality conditions and trace-metals transport in the study area prior to future mining activities. Water-quality models summarized in this report may be used to estimate constituent loads and concentrations with ongoing model validation using discrete samples. The monitoring network was designed to provide interpretable results that meet the following objectives:

- Identify and quantify contributions and transport of selected trace elements in discrete reaches between monitoring sites in the Stibnite mining area;

- Estimate the spatial and temporal variation in trace-metals and suspended-sediment loading and streamflow-weighted concentrations in the Stibnite mining area; and

- Evaluate continuous water-quality parameters and streamflow as surrogates to estimate concentrations of selected constituents.

\section{Description of Study Area}

Trace elements and sediment occurrence and transport were evaluated in the EFSFSR from the headwaters to the confluence with Sugar Creek and in the Sugar Creek watershed (fig. 1). The study area includes $42.9 \mathrm{mi}^{2}$ of steep mountain terrain ranging from 5,930 to 9,310 ft in elevation. Seventyone percent of the study area slopes at a gradient greater than 30 percent (U.S. Geological Survey, 2012), resulting in occasional mass wasting and substantial surface erosion during periods of rainfall and snowmelt runoff. Mean annual precipitation is 31 in., falling mostly as snow between October and April. Peak snowmelt and streamflow typically occur between May and July and low flows occur from September to January (Kuzis, 1997). Most of the study area is comprised of USFS public land in the Payette and Boise National Forests. Mining-related activity occurs on both private and public lands. Wildfires in 2000, 2006, and 2007 burned about 40 percent of the forested land in the MGI-proposed exploration area (fig. 1). Recent wildfires likely resulted in increased soil erosion and solar loading to surface-water bodies (U.S. Forest Service, 2012). Streams in the study area are critical habitat for Chinook salmon, steelhead, bull trout, and westslope cutthroat trout, which are all either threatened, endangered, or sensitive species (Idaho Department of Environmental Quality, 2002).

Mineralization and mineral extraction influence hydrogeology and water quality in the study area. The granitic Idaho batholith intruded the region in the Cretaceous 
period, leaving a roof of Neoproterozoic to Cambrian age metasedimentary rocks known as a roof pendant in the east side of the study area (Mitchell, 2000). Eocene mineralization occurred in a series of faults that cut through granitic and metasedimentary rocks, and Pleistocene glaciation deposited as much as $60 \mathrm{ft}$ of alluvium in valley floors (Larsen and Livingston, 1920). During low flow conditions, streams in the study area generally gain streamflow from shallow groundwater, which is present in seeps and springs at the surface and ranges to depths of about $20 \mathrm{ft}$ below the alluvial surface (URS Corporation, 2000). Depth to groundwater is deeper where mining waste materials have been placed. Groundwater also is present to a limited extent in fractured bedrock (Mitchell, 2000). Naturally occurring mineralized zones and mine tailings in contact with the water table act as sources of trace elements to both groundwater and surface water (Kuzis, 1997). Concentrations of dissolved metals are typically higher in groundwater than in surface water (Trainor, 1993; URS Corporation, 2000).

Water-quality conditions generally deteriorate in a downstream direction in the EFSFSR. In particular, concentrations of arsenic and antimony increase downstream of the confluence with Meadow Creek and between the confluences with Meadow and Sugar Creeks (URS Corporation, 2000). As streamflow increases in the EFSFSR, concentrations of sediment and sediment-associated metals including aluminum, iron, and mercury also increase. Suspended-sediment concentrations and total concentrations of some trace elements decrease as the EFSFSR flows past the Glory Hole, which acts as a sediment trap (Idaho Department of Environmental Quality, 2002). In May 2014, the Glory Hole was surveyed with a water surface elevation of $6,037.5 \mathrm{ft}$ and a maximum depth of $35.2 \mathrm{ft}$ (K. Fend, Midas Gold, written commun., 2014). Most surface-water-quality samples show similar concentrations of total and dissolved arsenic or antimony, indicating a groundwater source (URS Corporation, 2000). An negative correlation between streamflow and concentrations of arsenic and antimony also implicates groundwater as a source of arsenic and antimony in the study area. Concentrations of suspended sediment and sediment-associated metals such as aluminum and mercury are lower in filtered samples and higher in unfiltered samples, suggesting surface runoff as the largest contributing source. A positive correlation between streamflow and concentrations of suspended sediment, total aluminum, and total mercury also implicates surface runoff as a source of sediment, aluminum, and mercury in the study area. Sugar Creek is also a known source of mercury (Trainor, 1993; URS Corporation, 2000).

Water-quality samples and streamflow data from the five monitoring sites provided information necessary to evaluate the spatial and temporal transport of trace elements and suspended sediment (fig. 1, table 1). The EFSFSR monitoring site upstream of the confluence with Meadow Creek (site 1) quantifies constituent loads in the EFSFSR absent any loading from Meadow Creek. The monitoring site on Meadow Creek (site 2), upstream of the Bradley tailings disposal area, provided data used to quantify background water-quality conditions. Site 3 is on the EFSFSR about $1,300 \mathrm{ft}$ downstream of the confluence of Meadow Creek and the EFSFSR, and is used to quantify source contributions from the East Fork of Meadow Creek (also known as Blowout Creek) and the Bradley tailings disposal area. Site 4 is on the EFSFSR about 2,660 ft downstream of the Glory Hole and about $700 \mathrm{ft}$ upstream of the confluence with Sugar Creek and is used to quantify loads from ungaged tributaries, groundwater exchange along this reach, and the Glory Hole. Site 5, near the mouth of Sugar Creek, quantifies constituent loading from the Sugar Creek watershed including Cinnabar Creek, a known source of mercury contamination. Combined, hydrologic and water-quality data from sites 4 and 5 provide information on trace elements transport to the EFSFSR from the entire study area.

\section{Study Methods}

In October 2010 and September 2011, five monitoring sites were established as a network to provide information about trace elements and the occurrence and transport of suspended sediments in the study area (fig. 1). Hydrologic and water-quality data from each monitoring site were used in regression models to estimate constituent loads and concentrations. Estimated loads were compared between stations to identify source areas for trace elements and to quantify constituent loading in discrete reaches.

\section{Hydrologic Monitoring}

Streamflow at the five monitoring sites and water-quality sampling sites (fig. 1, table 1) was measured using standard USGS methods as described in Mueller and Wagner (2009) and Turnipseed and Sauer (2010). Continuous streamflow records were computed using methods described in Rantz and others (1982). Streamflow was computed using a continuous record of water stage calibrated to periodic streamflow measurements. Monitoring sites were operated year-round.

\section{Continuous Water-Quality Monitoring}

Water temperature, specific conductance, and $\mathrm{pH}$ were measured continuously at each of the monitoring sites. Continuous monitors were installed at sites $1-3$ in September 2011 and at sites 4 and 5 in April 2012. Continuous monitors were operated and continuous water-quality data were reviewed in accordance with Wagner and others (2006). Continuous water-quality monitors were operated seasonally (April to late October) and removed during the winter because of limited access and to prevent damage during extreme cold conditions. 


\section{Water-Quality Sampling and Analysis}

Discrete water-quality samples were routinely analyzed for total and dissolved concentrations of aluminum, antimony, arsenic, cadmium, chromium, copper, iron, lead, mercury, and zinc. Discrete water-quality samples were also routinely analyzed for acid neutralizing capacity (hardness) as calcium carbonate, and for major ions including dissolved calcium, magnesium, manganese, potassium, silica, sodium, chloride, fluoride, and sulfate. Water-quality constituents collected in the field included water temperature, specific conductance, and $\mathrm{pH}$.

Although the number of samples collected at each site varied, the approach at each site was designed to allocate samples over the full range of the station hydrograph to develop a robust relation between constituent concentration and streamflow. For example, samples collected at site 3 are plotted on the streamflow duration hydrograph to summarize hydrologic conditions during the sampling periods (fig. 2).

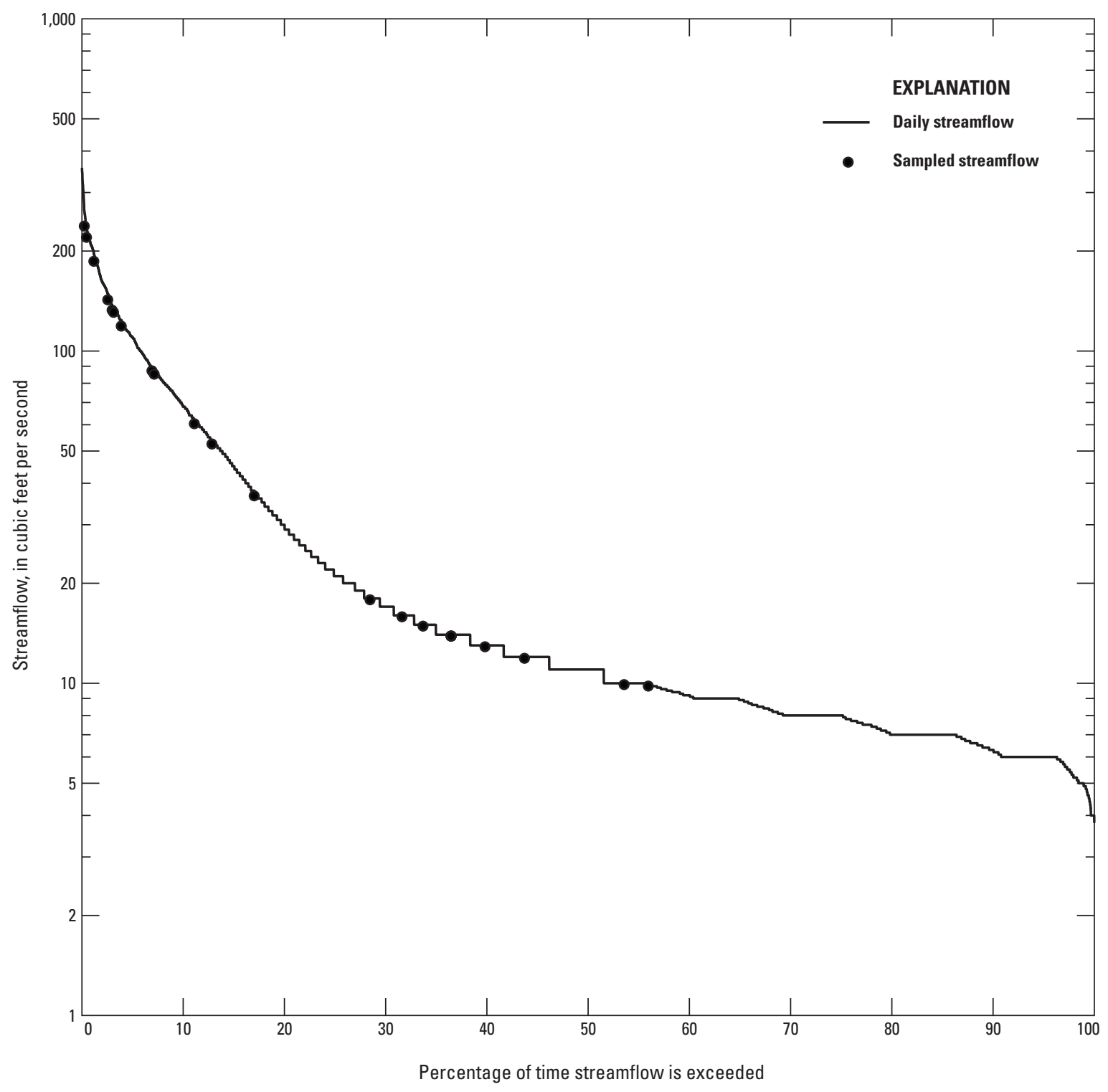

Figure 2. Streamflow duration (1928-2014) and measured streamflow at East Fork of South Fork of the Salmon River at Stibnite, central Idaho, 2012-14. 
Although the magnitude of measured streamflow differed among sites, the timing of sample collection over the streamflow hydrograph was similar at each site.

Water-quality samples at all sites were collected using nonmetallic samplers and cross-sectional, depth-integrated sampling procedures (U.S. Geological Survey, various dates). Most samples were collected isokinetically and in equal-width increments. However, low-streamflow conditions with shallow, slow moving water occasionally precluded isokinetic sample collection. Prior to installation of bank-operated cableways in October 2013, samples collected during high streamflow at sites 3 and 4 were collected non-isokinetically using multiple vertical transects. Minor variations in sample collection methods are documented in sample metadata stored in the USGS National Water Information System (U.S. Geological Survey, 2015). Sampling equipment was cleaned and samples were collected according to trace-metal protocols described in the USGS National Field Manual (U.S. Geological Survey, various dates). Samples for laboratory analyses were composited and subsampled using a polyethylene churn splitting device. Samples for whole-water recoverable (total) analyses were withdrawn directly from the splitting device. Samples for dissolved (smaller than 0.45-micrometer $[\mu \mathrm{m}]$ diameter) analyses were withdrawn directly from the churn splitter and filtered through a pre-rinsed, $0.45-\mu \mathrm{m}$ pore size, disposable capsule filter. Samples to be analyzed for trace elements were preserved with 2 milliliters $(\mathrm{mL})$ of Ultrex ${ }^{\circledR}$ nitric acid. Samples to be analyzed for mercury were preserved with $2 \mathrm{~mL}$ of Omni-Trace ${ }^{\circledast}$ hydrochloric acid. Samples were shipped in plastic coolers to the USGS National Water Quality Laboratory (NWQL) in Denver, Colorado.

All water-quality samples (excluding suspended sediment) were analyzed at the NWQL using established analytical techniques. Trace-element concentrations were determined at NWQL by atomic absorption spectrometry in conjunction with a graphite furnace and inductively coupled plasma-mass spectrometry (Fishman and Friedman, 1989; Fishman, 1993; Hoffman and others, 1996; Garbarino and Struzeski, 1998; Garbarino and others, 2005, 2006). Mercury concentrations were determined by atomic fluorescence spectrometry (Garbarino and Damrau, 2001). Suspended-sediment samples were analyzed for concentration and the weight percentage of particles less than $0.0625 \mathrm{~mm}$ by the USGS Cascades Volcano Observatory (CVO) Sediment Laboratory using methods described in Guy (1969) and the American Society for Testing and Materials (2002) method D3977-97. Quality-assurance/quality-control (QA/QC) procedures used at the NWQL were documented by Pritt and Raese (1995). The CVO Sediment Laboratory QA/QC procedures are described in Knott and others (1993). All the data collected as part of this study are publicly available from the USGS National Water Information System (U.S Geological Survey, 2015).

\section{Data Quality Assurance and Quality Control}

Water-quality sample results were reviewed after receipt of the laboratory analysis. Data validation included use of a relative percent difference (RPD) to evaluate the relation between dissolved concentrations and whole-water concentrations. RPDs were calculated using the absolute value of the difference between the result pair, divided by the mean of the result pair, multiplied by 100 . Expressing precision relative to a mean concentration standardizes comparison of precision among individual constituents. Laboratory analyses were rerun and (or) verified when the dissolved fraction exceeded the whole-water fraction with an RPD greater than 10 percent. Suspended-sediment results were reviewed for anomalies in comparison with historical results at the same location.

Analytical data also were validated using results from quality-control (QC) programs in use at the NWQL. The NWQL monitors and evaluates quality of inorganic analytical results through the use of double-blind QC samples as part of the Inorganic Blind Sample Project (IBSP). A "double-blind sample" is a QC sample submitted for analysis for which the identity of the sample and the concentration of the individual constituents within the sample are not known to the analyst. The QC samples typically are not synthetic reference materials; rather, they are derived from snowmelt, surface-water, or groundwater sources (Woodworth and Connor, 2003). Analytical errors settle into two major categories: bias and variability. Bias is systematic error that causes consistently positive or negative deviation in the results relative to the median expected concentration in the reference sample. Variability is random error that affects the ability to reproduce results. Repeated measurements of the IBSP samples over time provide estimates of systematic bias and random variability in the analytical procedures at the laboratory.

Quality-control samples also were collected in the field to evaluate the quality of the analytical results, and were analyzed concurrently in the laboratory with routine samples. Split replicates were collected and submitted at a proportion equivalent to at least 10 percent of the total number of water samples, and one field blank sample was collected during every sampling event.

Replicate data can be obtained in different ways to provide an assessment of precision (reproducibility) of analytical results. All replicate samples collected as part of this study were split replicates representing a single composite sample collected in the field and split into two subsamples for separate analysis. Analyses of split replicates indicate the reproducibility of environmental data that are affected by the combined variability potentially introduced by field and laboratory processes. The precision of the analytical results was determined using the RPD between the split replicates. An RPD of less than 20 percent for chemical analytes was considered acceptable. 
Occurrence and Transport of Selected Constituents in Streams near the Stibnite Mining Area, Central Idaho, 2012-14

Blank samples identify the presence and magnitude of potential contamination that could bias analytical results. Field blanks are aliquots of deionized water that are certified as contaminant free and are processed through the sampling equipment used to collect stream samples. All blanks were collected as field blanks. Field blanks are subjected to the same processing (sample splitting, filtration, preservation, transportation, and laboratory handling) as environmental samples. Field blanks included all sources of contamination associated with source-solution blanks plus any contamination from ambient conditions at sample sites. Field blanks also included any contamination from shipping or delivering the blanks to the analytical laboratory and storing, processing, and analyzing the blanks at the laboratory. Blank samples were analyzed for the same constituents as the environmental samples.

Summarized quality-assurance data analysis (appendix A) shows that dissolved cadmium and lead results from this study should be used with caution. Both analytes commonly were not detected at concentrations greater than the long-term method detection level (LT-MDL). Less frequently, dissolved cadmium and lead were detected near the laboratory LT-MDL at concentrations that did not exceed hardness-based AWQC.

\section{Model Development}

Two types of regression models were developed to estimate trace-metal and suspended-sediment transport and occurrence. The USGS LOAD ESTimator (LOADEST) FORTRAN program (Runkel and others, 2004; Runkel, 2013) was used to estimate daily and monthly loads. Estimated annual loads and total annual streamflow were used to compute streamflow-weighted concentrations (FWCs) of selected water-quality constituents. Surrogate regression models were developed using continuously monitored water-quality parameters, and optionally, functions of time and streamflow to estimate 15-minute and daily trace metal concentrations and loads.

\section{LOADEST Models for Estimating Constituent Loads}

For this study, loads were estimated for selected constituents using LOADEST. The LOADEST modeling program is based on a rating-curve method (Cohn and others, 1989, 1992; Crawford, 1991) that uses regression to estimate constituent concentrations and loads in relation to several predictor variables related to streamflow and time. This type of model has been used to estimate constituent concentrations for periods when sample data were not available (Gilroy and others, 1990), and to estimate a basin flux of water-quality constituents (Goolsby and others, 1999). Additional predictor variables describing streamflow variability were tested for significance in LOADEST models according to methods described by Garrett (2012).
Streamflow variability terms (SVTs) were defined in one of two ways. The first type of SVT was defined as the difference between mean streamflow $(Q)$ on day $i$ and the mean streamflow of the previous $k$ days, given as:

$$
d Q k=\sum_{j=i-k}^{i-1} \frac{\ln Q j}{k}
$$

This variability term (dQ) with a 1-day time step (dQ 1) helps describe effects of hysteresis (Wang and Linker, 2008). Hysteresis occurs when the value of a physical property (constituent concentration) changes at a different rate than the effect assumed to be causing it (streamflow). Use of a streamflow variability term eliminates the need to develop a different regression between streamflow and load on the rising compared to the falling limb of the hydrograph. A term with a 30-day step ( dQ 30) helps describe effects of sequential events or prolonged event peaks. In some instances, the absolute value of dQ $1(\mid d Q 1)$ better describes loads in the regression model than $d Q 1$, representing cases where the degree of flashiness of the event was the critical element, rather than hysteresis. In some instances, use of the untransformed streamflow also better describes loads in the regression model than the use of $\ln Q$.

The second type of SVT used the base-flow index (BFI) to explain streamflow variability. The BFI describes the amount of streamflow in a river derived from groundwater discharge using a simple ratio of estimated daily runoff to daily mean streamflow. Runoff was estimated using the local minimum method of hydrograph separation (Lim and others, 2005; Gustard and Demuth, 2009).

LOADEST was used for this study to develop regression models for estimating loads of arsenic, antimony, aluminum, manganese, lead, cadmium, zinc, mercury, and suspended sediment for each site. Because of the short duration of the study and to facilitate comparison among sites, predictor variables related to trends over time were not used. Data collected between September 2011 and October 2014 were used to calibrate the regression models, and constituent loads were estimated for 2012-14. The equation for the regression models is:

$$
\begin{aligned}
\ln L= & I+a(\ln Q)+b\left(\ln Q^{2}\right)+c[\sin (2 \pi T)] \\
& +d[\cos (2 \pi \mathrm{T})]+e(\mathrm{SVT})+\varepsilon
\end{aligned}
$$

where

$\ln \quad$ is the natural logarithm;

$\mathrm{L} \quad$ is the constituent load, in pounds per day;

I is the regression intercept;

Q is the centered streamflow, in cubic feet per second;

$T$ is the centered decimal time in years from the beginning of the calibration period; 


$$
\begin{aligned}
& \sin (2 \pi T) \quad \text { and } \\
& \cos (2 \pi \mathrm{T}) \text { are periodic time functions that describe } \\
& \text { seasonal variability; } \\
& \text { SVT is the term describing streamflow variability } \\
& \left(\mathrm{dQ} \mathrm{k}_{\mathrm{k}},\left|d Q_{k}\right|\right. \text {, or BFI); } \\
& \begin{array}{c}
a, b, c, d, e \quad \begin{array}{l}
\text { are regression coefficients that remain } \\
\text { constant over time; and }
\end{array} \\
\varepsilon \quad \begin{array}{l}
\text { is the unaccounted error associated with the } \\
\text { regression model. }
\end{array}
\end{array}
\end{aligned}
$$

For each model, time and streamflow predictor variables in the regression equation were selected on the basis of Akaike Information Criterion (Akaike, 1981; Judge and others, 1985). The criterion is designed to achieve a good compromise between using as many predictor variables as possible to explain the variance in load while minimizing the standard error of the resulting estimates. The streamflow variability predictor variable was selected based on its significance level. Estimates of the daily constituent load for each site were computed using the selected model and daily mean streamflow. Bias introduced by conversion of the logarithm of load into estimates of actual load was corrected using the Bradu-Mundlak method (Bradu and Mundlak, 1970; Cohn and others, 1989; Crawford, 1991).

\section{Surrogate Regression Models for Estimating Constituent Concentrations}

Multiple linear regression models were developed using continuously monitored water-quality parameters (surrogates) to estimate concentrations of dissolved arsenic, dissolved antimony, and total mercury at selected sites. Functions of time and discharge also were used as predictor variables in surrogate regression models if determined to be significant. Surrogate models were developed using stepwise linear regression analysis as described in Wood and Etheridge (2011) using the U.S. Geological Survey R statistical programming package "GSqwsr" (DeCicco and Corsi, 2014). The functional form of the surrogate models is:

$$
\begin{aligned}
C= & I+a(S C)+b(\ln S C)+c(Q)+d(\ln Q) \\
& +e[\sin (2 \pi T)]+f[\cos (2 \pi T)]+g(\mathrm{BFI})
\end{aligned}
$$

where

$$
\begin{aligned}
\text { C is the constituent concentration, in } \\
\text { micrograms per liter; } \\
\text { is the y-intercept; and } \\
\text { a,c,... are regression coefficients. }
\end{aligned}
$$

Surrogate models were calibrated using 15-minute values of continuously monitored streamflow and water-quality parameters in conjunction with laboratory analytical results for environmental samples.

\section{Calculation of Streamflow-Weighted Concentrations using LOADEST Results}

Interpretation of concentrations of trace elements in streams is improved by examining the mean FWC spanning a specified time period rather than individual concentrations or statistics based on a dataset of individual concentrations. An FWC is an estimate of the mean concentration in a total volume of water flowing past a site during a specific period, such as a year, or group of years. For this study, a mean FWC at each site was calculated using the LOADEST result for a constituent load during a given water year or wateryear span divided by the total streamflow during that water year or water-year span. Loads and FWCs were estimated for each water year (2012-14) and as a mean for the 3-year study period.

\section{Statistical Analysis of Sample Results}

Summary statistics are provided for concentrations of all analyzed constituents and are compared with applicable ambient water-quality criteria (AWQC). Concentrations of total and dissolved mercury, cadmium, lead, and zinc, as well as dissolved manganese, were commonly lower than applicable LT-MDLs and LOADEST (which requires 7 detections to compute regression estimates); could not be used to estimate loads; and, thus, mean FWCs could not be determined for these constituents at all sites in the study area. The maximum likelihood estimation (MLE) method was used to estimate summary statistics on censored sample results. Logarithmic transformation was used with MLE as necessary to normalize the distribution of censored results (Helsel, 2012). Summary statistics were calculated from the data when less than 25 percent of the results were censored (Helsel and Hirsch, 2002).

\section{Ambient Water-Quality Criteria}

Streamflow-weighted concentrations and (or) summary statistics of constituent concentrations were compared to applicable AWQC. Comparisons of measured AWQC values for trace metals are complicated because criteria change as a function of water hardness. For this assessment, chronic freshwater AWQC concentrations were based on the applicable State of Idaho criteria for the protection of aquatic life (Idaho Department of Environmental Quality, various dates). Representative chronic criteria values were calculated using the minimum hardness value measured in samples collected from each site. The statewide cadmium criterion is from Mebane (2006) and the statewide zinc criterion is from U.S. Environmental Protection Agency (2002). 


\section{Streamflow and Water-Quality Monitoring}

Monitoring sites in the study area were established in September 2011 except for site 3, operated from 1928-42, 1983-97, and 2011-14. Statistics for the 50th and 90th percentiles of streamflow over 32 years of record at site 3 show that peak snowmelt runoff occurred earlier in the water year during the study period (fig. 3). Sample-collection timing shown on the hydrograph for site 3 suggests that streamflows at all sites likely included the 90th percentile of streamflow (figs. 2 and 3). Concentrations of suspended sediment and sediment-associated constituents generally were highest in the samples collected during peak streamflows in May 2013, possibly because snowmelt runoff in 2013 occurred as a single peak with higher capacity to mobilize, transport, and concentrate sediment near the peak of snowmelt runoff.

Samples were collected after relatively short-duration rainfall runoff events in October 2011 and August 2014, but were not collected on the rising limb of the hydrograph for any rainfall runoff event.

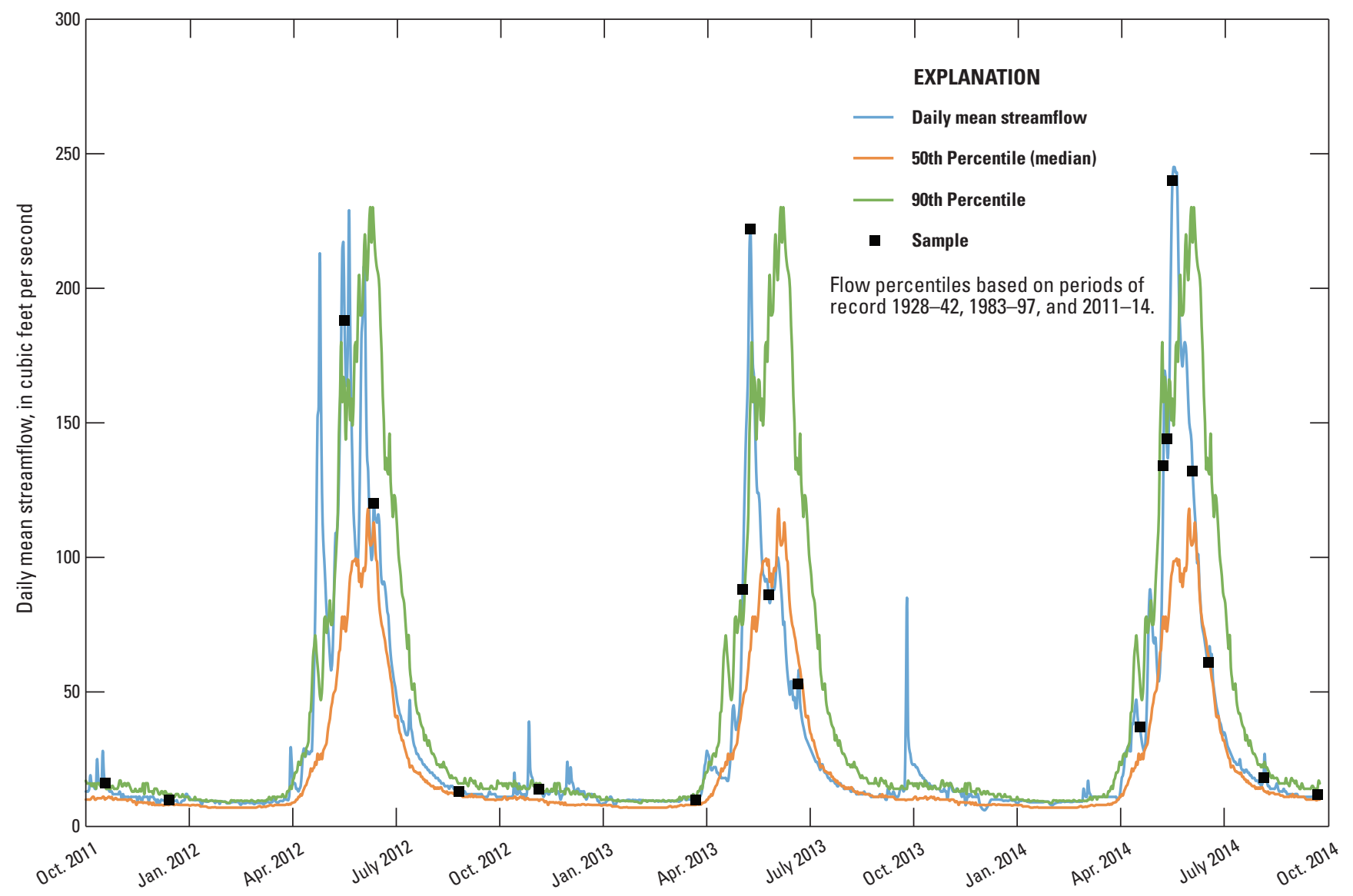

Figure 3. 50th and 90th streamflow percentiles for the periods of record, daily mean streamflow, and timing of waterquality sample collection at East Fork of South Fork of the Salmon River at Stibnite, central Idaho, 2012-14. 
Except for arsenic, antimony, and mercury, concentrations of trace elements in streams in the EFSFSR (sites 1, 3, and 4), Meadow Creek (site 2), and Sugar Creek (site 5) did not exceed applicable AWQC or human-health criteria (appendix B, table 2). Arsenic concentrations exceeded the human-health-based criterion of $10 \mu \mathrm{g} / \mathrm{L}$ in all samples collected in the EFSFSR at stations 3 and 4 downstream of the confluence with Meadow Creek. Antimony concentrations exceeded the human-health based criterion of $5.6 \mu \mathrm{g} / \mathrm{L}$ in 87 percent of the samples collected from site 3 and 100 percent of the samples collected from site 4 . Every site had at least one exceedance of the $0.012-\mu \mathrm{g} / \mathrm{L}$ chronic AWQC for total mercury, and two samples from site 5 exceeded the $2.1-\mu \mathrm{g} / \mathrm{L}$ acute AWQC for total mercury (table 2, fig. 4, appendix A). Concentrations of regulated trace elements, including cadmium, copper, and zinc, were detected infrequently and did not exceed the AWQC. Water-quality sample results for chromium were not speciated, but dissolved and total chromium were not detected at concentrations higher than hardness-dependent AWQC for hexavalent chromium.

Table 2. Exceedances of water-quality criteria in samples collected from five streamflow and water-quality monitoring sites in the Stibnite mining area, central Idaho, 2012-14.

[Site names and locations are shown in table 1 and figure 1, respectively. Applicable criteria: Criteria shown are not hardness-dependent. MDAT, maximum daily average water-temperature criterion for coldwater aquatic life; MDAT-SS, maximum daily average water-temperature criterion for salmonid spawning; MDMT, maximum daily maximum water-temperature criterion for salmonid spawning; MWMT, maximum weekly maximum water-temperature criterion for bull trout habitat. C riterion type: HHB, human-health based criterion; CCC, criterion continuous concentration or "chronic" aquatic-life criterion; CMC, criterion maximum concentration or "acute" aquatic-life criterion; CW, coldwater; SS, salmonid spawning; BT, bull trout. A bbreviations: $\mu$ g/L, microgram per liter; ${ }^{\circ} \mathrm{C}$, degrees Celcius; $<$, less than; NA, not applicable]

\begin{tabular}{|c|c|c|c|c|c|c|c|}
\hline Constituent & Applicable criteria & $\begin{array}{c}\text { Criterion } \\
\text { type }\end{array}$ & Site 1 & Site 2 & Site 3 & Site 4 & Site 5 \\
\hline \multirow[t]{2}{*}{ Dissolved arsenic } & Minimum: $10 \mu \mathrm{g} / \mathrm{L}$ & HHB & 45 & 0 & 100 & 100 & 48 \\
\hline & Number of samples & NA & 20 & 21 & 24 & 22 & 21 \\
\hline Dissolved antimony & Miniumum: $5.6 \mu \mathrm{g} / \mathrm{L}$ & НHB & 0 & 0 & 87 & 100 & 30 \\
\hline \multirow[t]{3}{*}{ Total mercury } & Miniumum: $0.012 \mu \mathrm{g} / \mathrm{L}$ & $\mathrm{CCC}$ & 43 & 14 & 46 & 33 & 95 \\
\hline & Maximum: $2.1 \mu \mathrm{g} / \mathrm{L}$ & $\mathrm{CMC}$ & 0 & 0 & 0 & 0 & 11 \\
\hline & Number of samples & NA & 7 & 7 & 13 & 15 & 19 \\
\hline Water temperature $^{1}$ & MDAT: $19^{\circ} \mathrm{C}$ & $\mathrm{CW}$ & 0 & 0 & 0 & 0 & 0 \\
\hline
\end{tabular}

${ }^{1}$ Water-temperature data collected seasonally (April-October) every 15 minutes from each site were assessed with applicable criteria. A 7-day average was computed from 15-minute values and used to assess the MWMT. A daily average was computed from 15-minute values and used to assess the MDAT and MDAT-SS. 


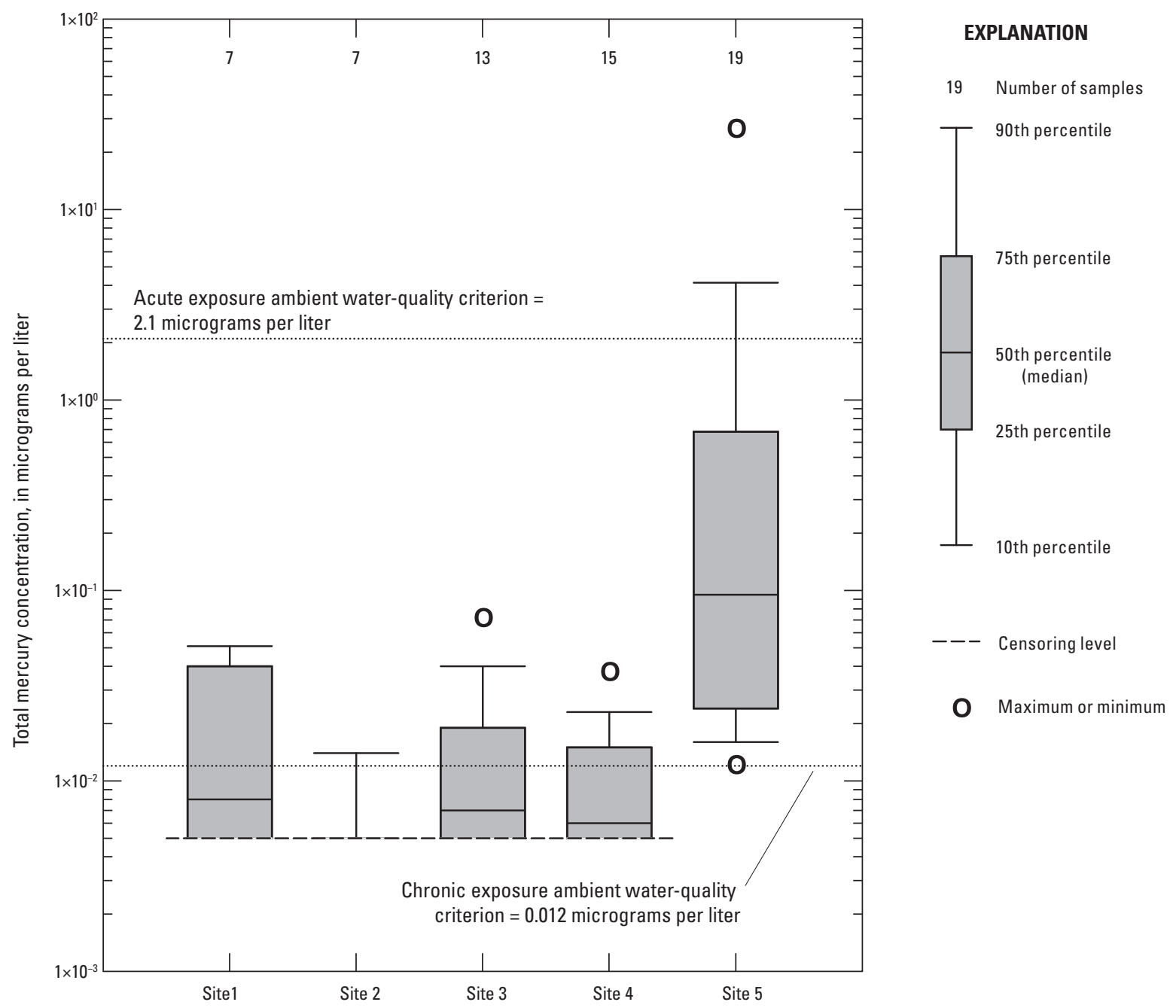

Figure 4. Total mercury concentrations in five streamflow and water-quality monitoring sites in the Stibnite mining area, central Idaho, 2012-14. Site names and locations are shown in table 1 and figure 1, respectively.

Continuous measurements of stream temperature and $\mathrm{pH}$ showed few exceedances of applicable State-of-Idaho general water-quality criteria (Idaho Department of Environmental Quality, various dates). $\mathrm{pH}$ was greater than the general minimum criterion of 6.5 and less than the general maximum criterion of 9.0 at all of the sites.

Applicable salmonid spawning criteria in the South Fork of the Salmon River and its tributaries apply to seasonal periods between March 15 and July 1 for spring spawning salmonids (steelhead), and between August 15 and June 1 of the following year for autumn-spawning salmonids (Chinook salmon) (Idaho Department of Environmental
Quality, 2012). Therefore, seasonal salmonid spawning criteria apply during a substantial part of the year because of the presence of both spring and autumn salmonid spawners. Continuous water-temperature data collected from late April to late October during 2012-14 showed that water temperature exceeded the $9{ }^{\circ} \mathrm{C}$ maximum daily average temperature criterion for salmonid spawning (MDAT-SS) at least 29 percent of the time at all sites (table 2, fig. 5). Water temperature at sites 3 and 4 in the EFSFSR and site 5 in Sugar Creek exceeded the $13{ }^{\circ} \mathrm{C}$ maximum daily maximum temperature (MDMT) criterion for salmonid spawning between 4 and 9 percent of the time (table 2, fig. 5). 


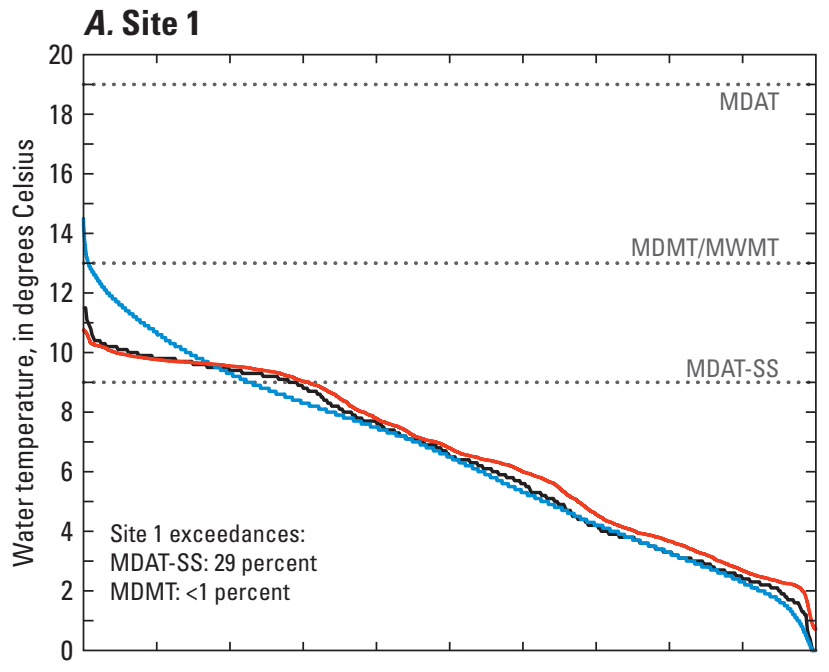

\section{Site 3}

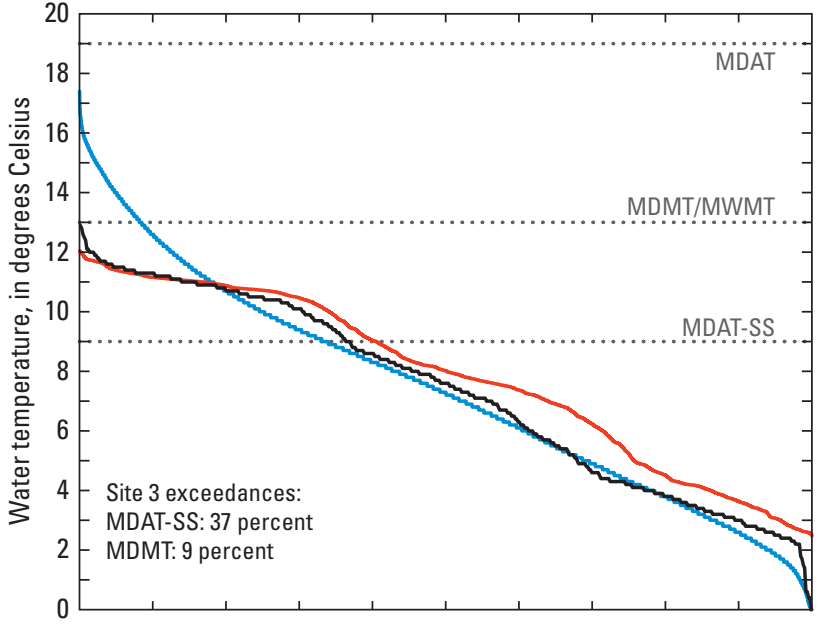

\section{E. Site 5}

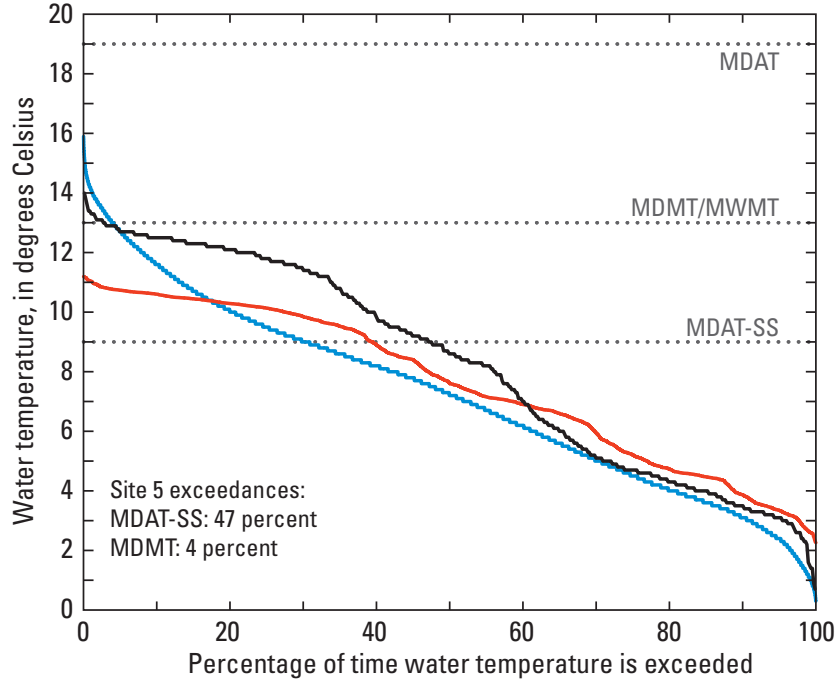

B. Site 2

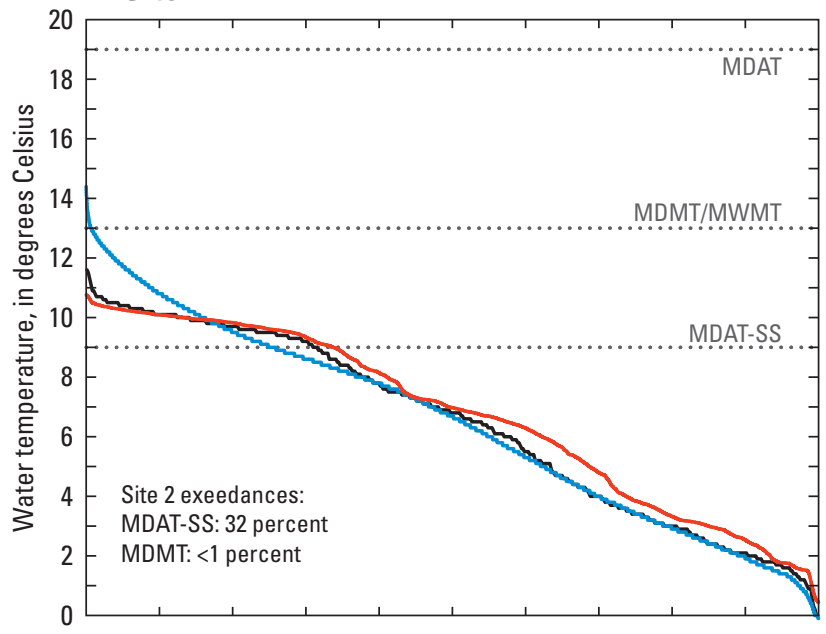

\section{Site 4}

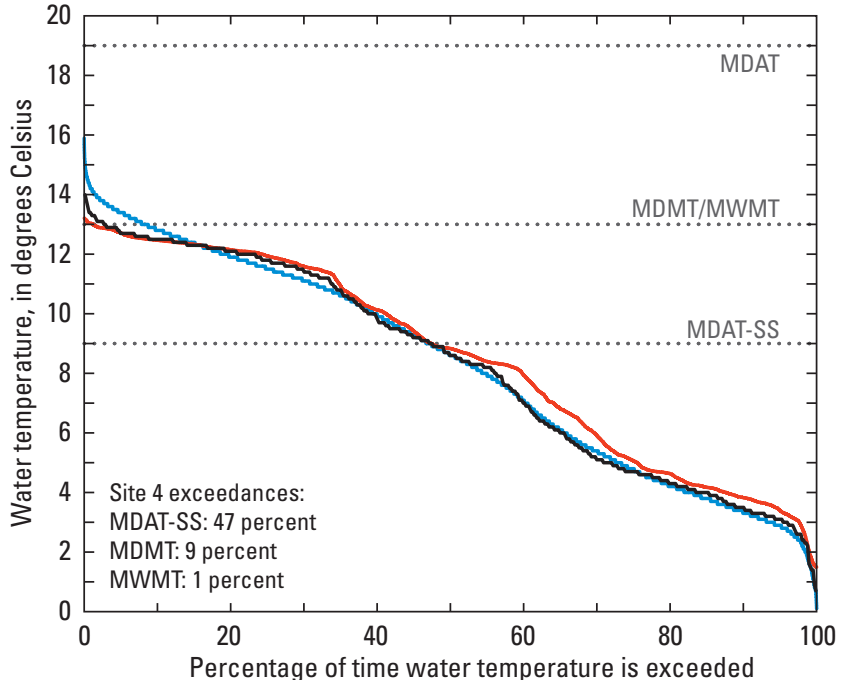

EXPLANATION

15-minute temperature values (used to assess MDMT)

7-day moving average of 15-minute values (used to assess MWMT)

Daily average temperature values recorded (used to assess MDAT and MDAT-SS)

Criterion:

MDAT Maximum daily average water temperature (MDAT) for coldwater aquatic life $=19^{\circ} \mathrm{C}$

MDMT Maximum daily maximum water temperature (MDMT) for salmonid spawning $=13^{\circ} \mathrm{C}$

MWMT Maximum weekly maximum water temperature (MWMT) for bull trout habitat $=13^{\circ} \mathrm{C}$

MDAT-SS Maximum daily average water temperature (MDAT-SS) for salmonid spawning $=9^{\circ} \mathrm{C}$

Figure 5. Temperature exceedance for five streamflow and water-quality monitoring sites in the Stibnite mining area, central Idaho, 2012-14. Site names and locations are shown in table 1 and figure 1, respectively. 


\section{Occurrence, Transport, and Deposition of Selected Constituents}

Occurrence and transport of trace elements and suspended sediment in the Stibnite mining area depend on constituent source. Groundwater sources seem to control concentrations and loading of dissolved and total arsenic, dissolved and total antimony, dissolved manganese, and dissolved iron, whereas erosion and overland runoff control concentrations and loading of suspended sediment and sediment-associated constituents including aluminum, lead, and mercury. Ratios of dissolved to total estimated FWCs of arsenic and antimony are close to 1 in the EFSFSR, indicating that they are primarily in the dissolved phase, and probably are derived from groundwater sources (table 3). Negative correlations between streamflow and concentrations of total and dissolved arsenic, total and dissolved antimony, dissolved manganese, and dissolved iron also suggest groundwater sources for these constituents in the Meadow Creek and (or) Glory Hole reaches (figs. 1 and 6). Ratios of dissolved to total estimated FWCs of lead and aluminum are relatively low, and concentrations of aluminum, lead, mercury, total iron, and suspended sediment are positively correlated with streamflow, indicating surface and stream channel erosion as sources (table 3, fig. 6). LOADEST models were not used to estimate annual loads or FWCs of cadmium, chromium, copper, and zinc because of a low rate of detection throughout the study area and the requirement of at least seven uncensored values to calibrate LOADEST models (appendix A). Laboratory analytical results for dissolved antimony often were slightly higher than for total antimony, resulting in ratios of greater than 1 for FWCs of dissolved to total antimony. When this occurred, ratios were rounded down to 1 in table 3 . Total manganese was not analyzed in waterquality samples.

Estimated annual loads and FWCs for each site indicate that the Glory Hole reach between sites 3 and 4 (fig. 1) is the primary source of arsenic, antimony, and dissolved manganese in the study area (figs. 7-11, tables 4 and 5). On average, the Glory Hole reach contributed only 10 percent of the streamflow, but contributed 52 percent of total arsenic, 53 percent of total antimony, and 42 percent of the dissolved manganese loads attributable to streams in the study area (fig. 7). The Meadow Creek reach was the second largest source of arsenic, antimony, and dissolved manganese. On average, the Meadow Creek reach contributed only 15 percent of the streamflow, but 28 percent of total arsenic, 37 percent of total antimony, and 44 percent of the dissolved manganese loads attributable to streams in the study area (fig. 7). Mean estimated FWCs exceed human-health criteria for arsenic at sites 3, 4 and 5 and antimony at sites 3 and 4 . Based on incremental changes in the streamflow between sites and the loads of arsenic, antimony, and dissolved manganese between sites, a mean FWC of sources to the reach can be estimated. Estimated FWCs from the Glory Hole reach and the Meadow Creek reach indicate that those reaches have much higher concentrations compared to the monitoring sites immediately downstream (fig. 11). Water-quality samples were collected at numerous locations along the Meadow Creek reach between sites 2 and 3 on September 22, 2011, in an effort to identify sources of arsenic and antimony to Meadow Creek. Five samples collected at discrete sampling sites on September 22, 2011 (as opposed to regularly collected samples from monitoring sites) showed substantially higher concentrations and loads of arsenic or antimony relative to concentrations and loads measured at the adjacent upstream location (table 6, fig. 12). Results from all samples collected along Meadow Creek on September 22, 2011, are available from the USGS National Water Information System (U.S. Geological Survey, 2015).

Estimated annual loads and FWCs of suspended sediment, total aluminum, and total lead generally increased between sites 1 and 3 and decreased between sites 3 and 4, with the Glory Hole acting as a sediment trap (figs. 7, 13, 14, and 16; tables 4 and 5; appendix B). Although not sampled as part of this study, the East Fork Meadow Creek (fig. 1) likely is the source of suspended sediment and total aluminum load entering the Meadow Creek reach. The East Fork Meadow Creek is the only surface-water tributary to Meadow Creek capable of carrying a sediment (and sediment-associated constituent) load. The Meadow Creek reach contributed more sediment than Sugar Creek (site 5), but most of the sediment load discharged from the Meadow Creek reach was deposited in the Glory Hole (figs. 7 and 13). The FWCs of suspended sediment at sites 1 and 2 were less than $10 \mathrm{mg} / \mathrm{L}$. However, the incremental gain between sites 1 and 2 downstream to site 3 indicates that the sources of suspended sediment to the Meadow Creek reach had a mean FWC of $78 \mathrm{mg} / \mathrm{L}$ (fig. 16C). The mean FWC of suspended sediment for 2012-14 at site 3 was nearly 4 times higher than the corresponding FWC of suspended sediment at site 4 (table 5). Load models show that about 90 percent of the coarse-grained sediment $(>0.0625 \mathrm{~mm}$ in diameter) load at site 3 was deposited in the Glory Hole; however, about 82 percent of the fine-grained sediment $(<0.0625 \mathrm{~mm}$ in diameter) load at site 3 was transported through the Glory Hole downstream to site 4 (table 4). 
Table 3. Ratio of dissolved to total mean streamflow-weighted concentrations for selected constituents at five streamflow and waterquality monitoring sites in the Stibnite mining area, central Idaho, 2012-14.

[Site names and locations are shown in table 1 and figure 1, respectively. Ratios are unitless. A bbreviations: FWC, streamflow-weighted concentration; NA, not applicable]

\begin{tabular}{lccccc}
\hline \multirow{2}{*}{ Constituent } & \multicolumn{5}{c}{ Ratio of dissolved to total mean FWC 2012-14 } \\
\cline { 2 - 6 } & Site 1 & Site 2 & Site 3 & Site 4 & Site 5 \\
\hline Arsenic & 0.96 & 0.67 & 0.97 & 0.93 & 0.88 \\
Antimony & 1.00 & 1.00 & 0.97 & 1.00 & 1.00 \\
Lead & NA & NA & 0.11 & 0.30 & 0.20 \\
Aluminum & 0.23 & 0.12 & 0.08 & 0.13 & 0.08 \\
\hline
\end{tabular}

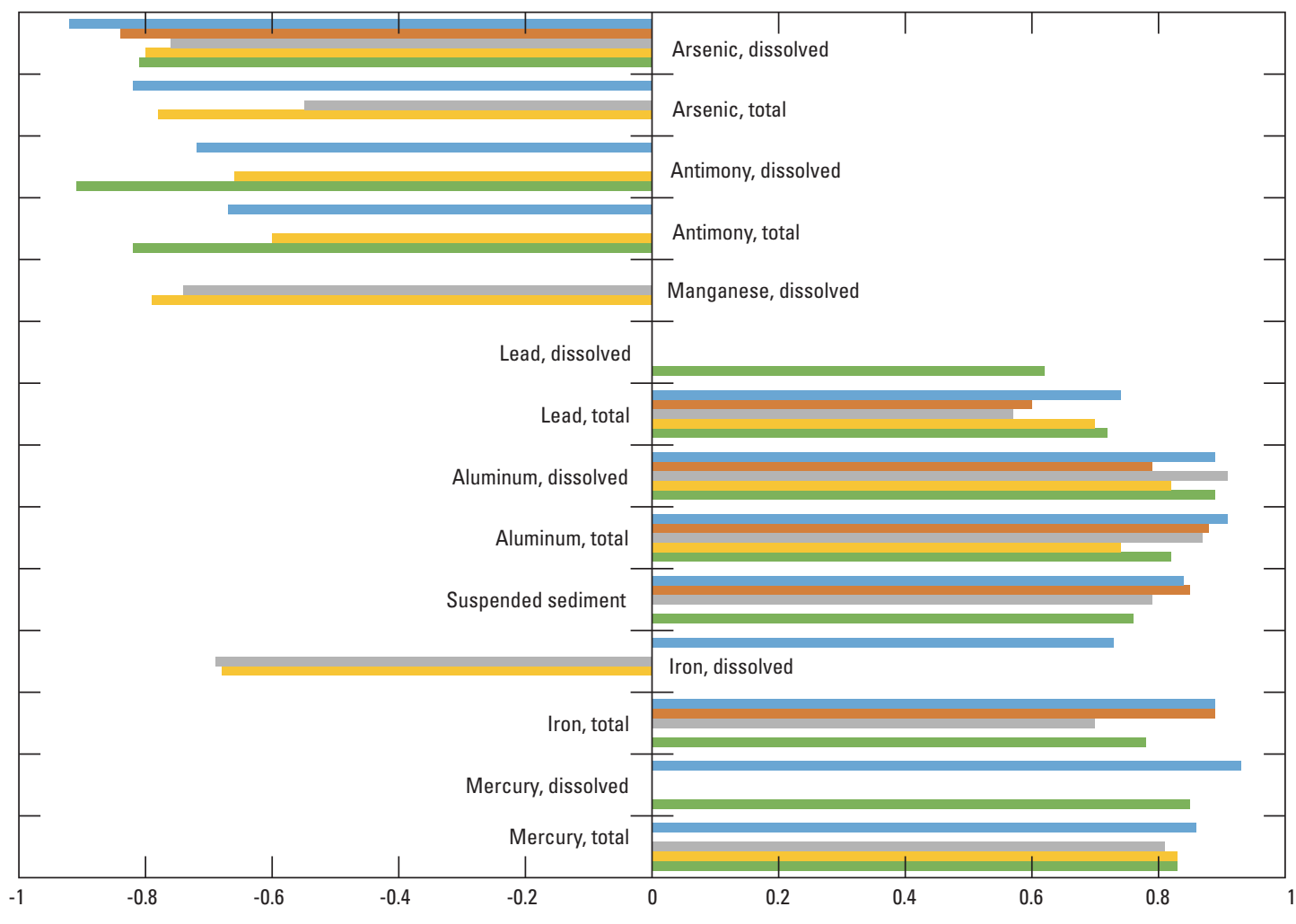

EXPLANATION

Site 1

- Site 2

Site 3

Site 4

Site 5

No bar is shown for constituents not significantly correlated with streamflow.

Statistically significant $(p<0.01)$ Spearman's rho correlation coefficients between streamflow and concentration, dimensionless

Figure 6. Correlation between streamflow and constituent concentrations for trace elements and suspended sediment in streams in the Stibnite mining area, central Idaho, 2012-14. Site names and locations are shown in table 1 and figure 1, respectively. 
Total arsenic

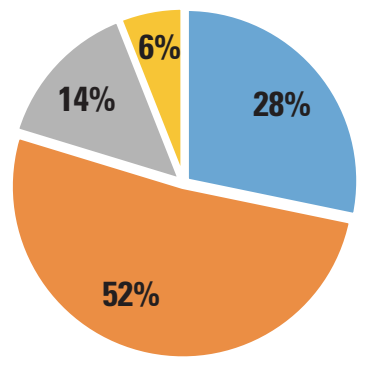

Dissolved aluminum

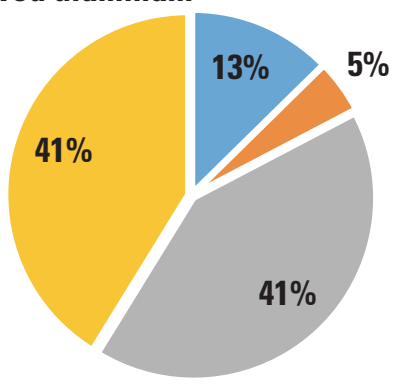

Fine sediment

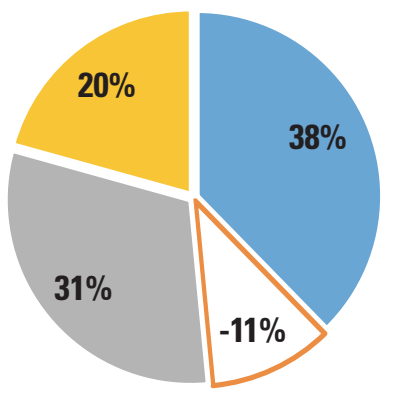

\section{EXPLANATION}

Sites 1 and 2 combined

Meadow Creek Reach

Glory Hole Reach

Glory Hole Reach (losses)

Sources upstream of Site 4

Site 5 (Sugar Creek)
Total antimony $2 \%$

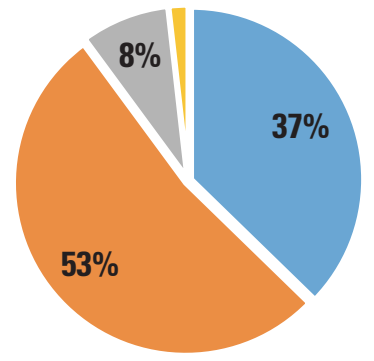

Total aluminum

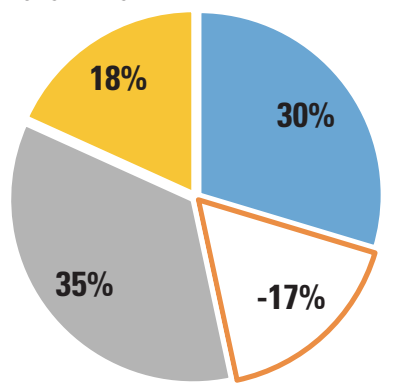

Coarse sediment

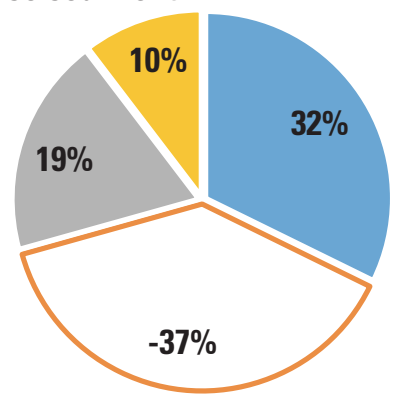

Dissolved manganese

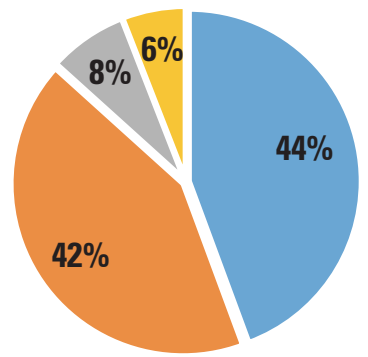

\section{Suspended sediment}

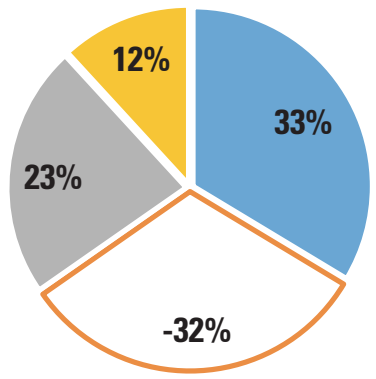

Total mercury $2 \%$

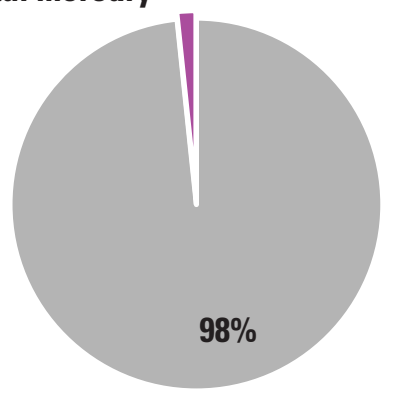

Streamflow

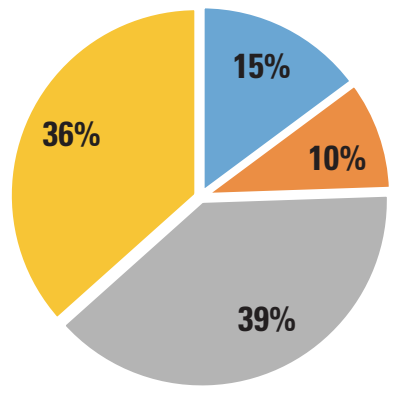

Figure 7. Streamflow and load contributions from discrete reaches as a percentage of total estimated streamflow and loads attributable to streams in the Stibnite mining area, central Idaho, 2012-14. 


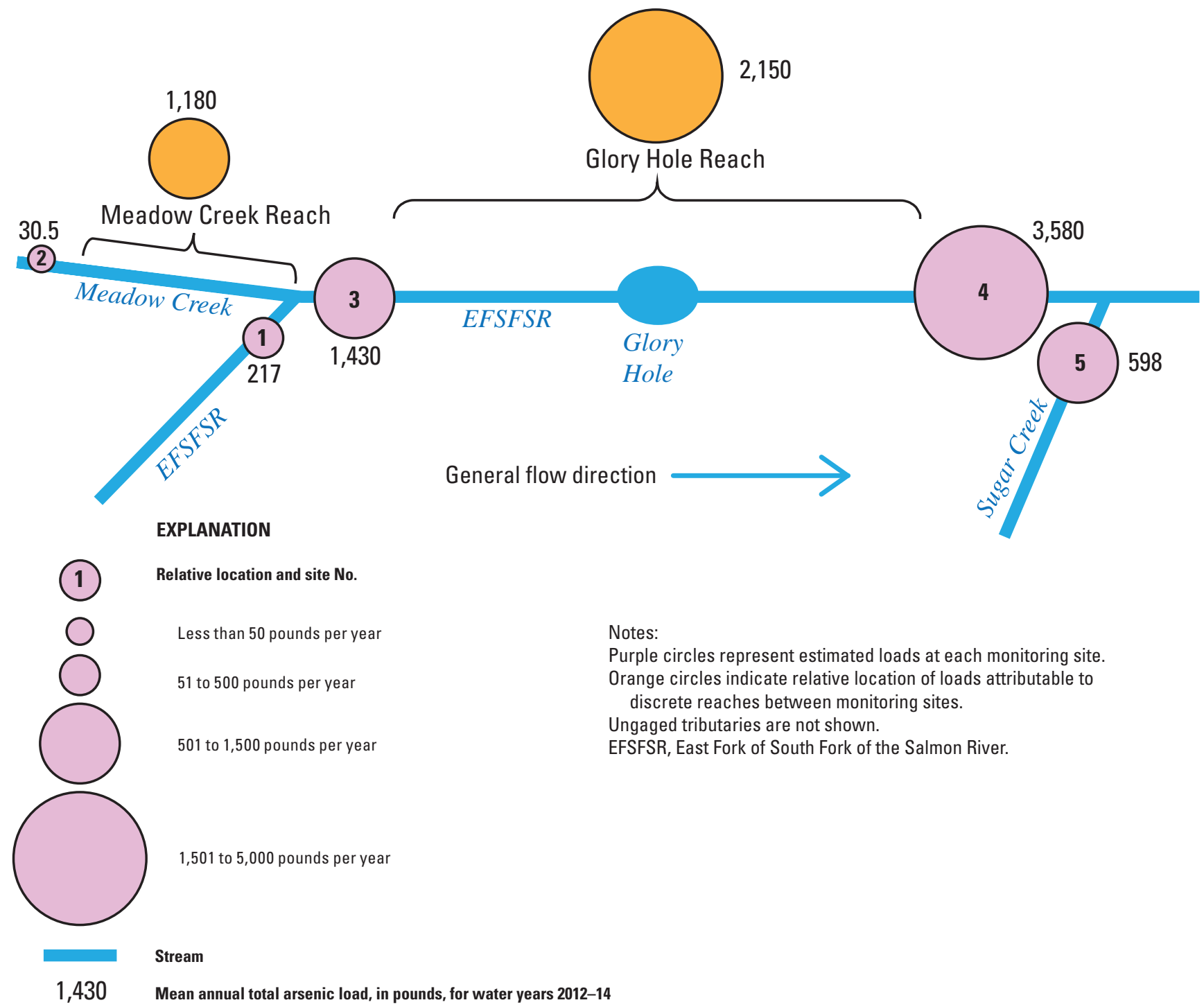

Figure 8. Estimated mean annual total arsenic loads in streams in the Stibnite mining area, central Idaho, 2012-14. Site names and locations are shown in table 1 and figure 1, respectively. 


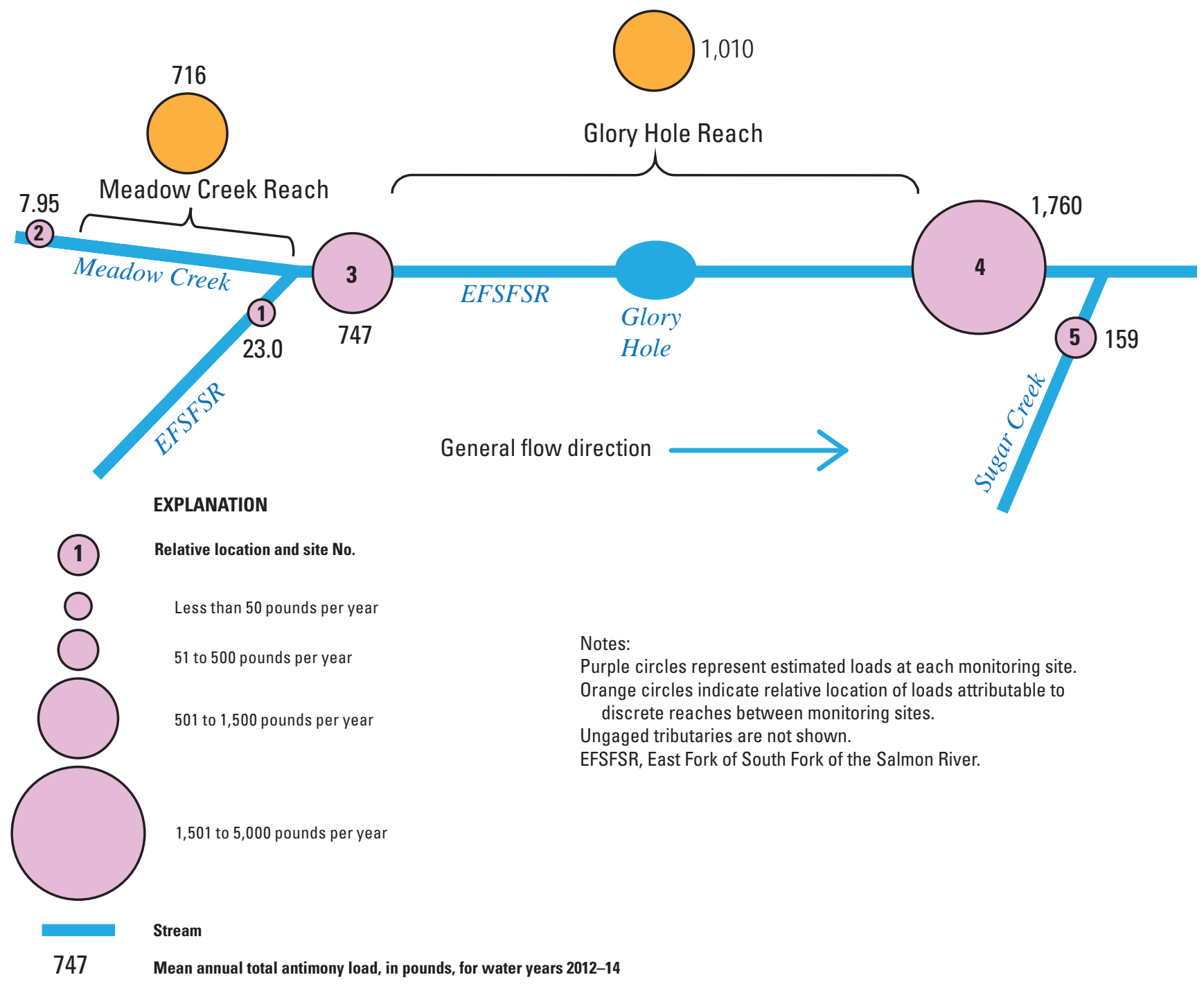

Figure 9. Estimated mean annual total antimony loads in streams in the Stibnite mining area, central Idaho, 2012-14. Site names and locations are shown in table 1 and figure 1, respectively. 

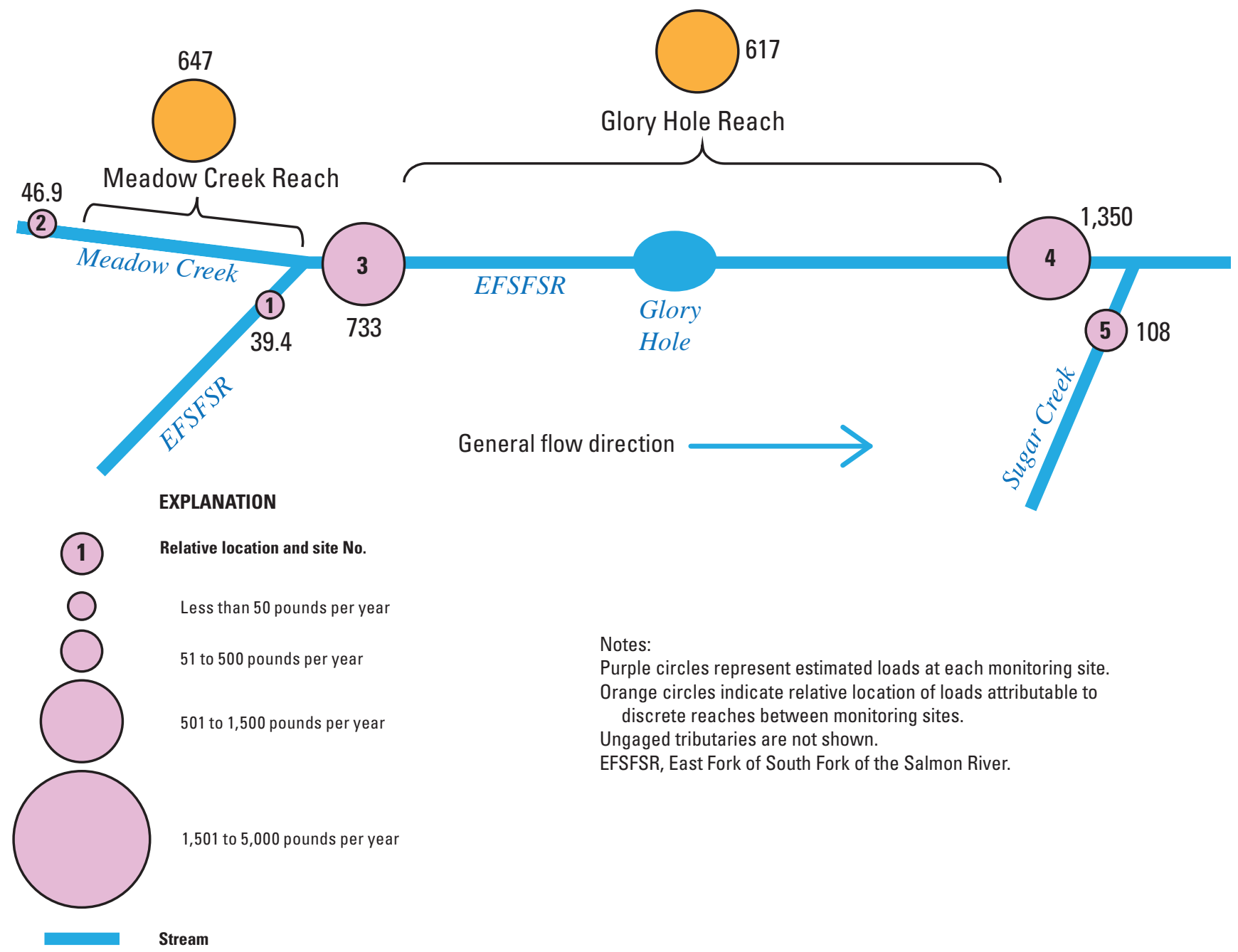

Notes:

Purple circles represent estimated loads at each monitoring site. Orange circles indicate relative location of loads attributable to discrete reaches between monitoring sites. Ungaged tributaries are not shown. EFSFSR, East Fork of South Fork of the Salmon River.

Mean annual dissolved manganese load, in pounds, for water years 2012-14

Figure 10. Estimated mean annual dissolved manganese loads in streams in the Stibnite mining area, central Idaho, 2012-14. Site names and locations are shown in table 1 and figure 1, respectively. 
Table 4. Estimated annual loads of selected trace elements and suspended sediment at five streamflow and water-quality monitoring sites in the Stibnite mining area, central Idaho, 2012-14.

[Site names and locations are shown in table 1 and figure 1, respectively. Abbreviations: L95, lower 95-percent confidence interval; U95, upper 95-percent confidence interval; $1 \mathrm{~b} / \mathrm{yr}$, pound per year; ton/yr, ton per year]

\begin{tabular}{|c|c|c|c|c|c|c|c|c|c|c|c|c|}
\hline \multirow{3}{*}{ Constituent } & \multicolumn{12}{|c|}{ Water year } \\
\hline & \multicolumn{3}{|c|}{2012} & \multicolumn{3}{|c|}{2013} & \multicolumn{3}{|c|}{2014} & \multicolumn{3}{|c|}{ 2012-14 mean } \\
\hline & $\begin{array}{c}\text { Annual } \\
\text { load }\end{array}$ & L95 & U95 & $\begin{array}{c}\text { Annual } \\
\text { load }\end{array}$ & L95 & U95 & $\begin{array}{c}\text { Annual } \\
\text { load }\end{array}$ & L95 & U95 & $\begin{array}{c}\text { Annual } \\
\text { load }\end{array}$ & L95 & U95 \\
\hline \multicolumn{13}{|c|}{ Site 1} \\
\hline Arsenic, dissolved (lb/yr) & 223 & 208 & 238 & 197 & 183 & 211 & 206 & 193 & 220 & 209 & 195 & 223 \\
\hline Antimony, dissolved (lb/yr) & 26.1 & 23.3 & 29.1 & 22.9 & 20.3 & 25.8 & 23.4 & 20.8 & 26.2 & 24.1 & 21.5 & 27.0 \\
\hline Antimony, total (lb/yr) & 24.7 & 21.8 & 27.9 & 21.7 & 19.0 & 24.7 & 22.6 & 19.9 & 25.6 & 23.0 & 20.2 & 26.1 \\
\hline Manganese, dissolved (lb/yr) & 43.7 & 29.5 & 62.4 & 34.8 & 23.6 & 49.7 & 39.6 & 26.4 & 57.2 & 39.4 & 26.5 & 56.5 \\
\hline Lead, dissolved (lb/yr) & \multicolumn{12}{|c|}{ no suitable LOADEST model } \\
\hline Lead, total (lb/yr) & \multicolumn{12}{|c|}{ no suitable LOADEST model } \\
\hline Aluminum, dissolved (ton/yr) & 0.36 & 0.27 & 0.46 & 0.27 & 0.20 & 0.35 & 0.32 & 0.24 & 0.42 & 0.32 & 0.24 & 0.41 \\
\hline \multicolumn{13}{|c|}{ Site 2} \\
\hline Arsenic, dissolved (lb/yr) & 21.2 & 20.3 & 22.2 & 18.2 & 17.4 & 19.0 & 21.9 & 21.0 & 23.0 & 20.5 & 19.6 & 21.4 \\
\hline Arsenic, total (lb/yr) & 32.2 & 27.5 & 37.5 & 25.7 & 22.0 & 29.8 & 33.6 & 28.4 & 39.3 & 30.5 & 26.0 & 35.5 \\
\hline Antimony, dissolved (lb/yr) & 8.69 & 7.78 & 9.68 & 7.28 & 6.45 & 8.18 & 8.96 & 8.00 & 10.0 & 8.31 & 7.41 & 9.29 \\
\hline Antimony, total (lb/yr) & 8.46 & 7.11 & 9.98 & 6.74 & 5.71 & 7.90 & 8.65 & 7.28 & 10.21 & 7.95 & 6.70 & 9.36 \\
\hline Manganese, dissolved (lb/yr) & 49.0 & 36.2 & 64.9 & 41.1 & 31.0 & 53.5 & 50.5 & 37.5 & 66.6 & 46.9 & 34.9 & 61.7 \\
\hline Lead, dissolved (lb/yr) & \multicolumn{12}{|c|}{ no suitable LOADEST model } \\
\hline Lead, total (lb/yr) & \multicolumn{12}{|c|}{ no suitable LOADEST model } \\
\hline Aluminum, dissolved (ton/yr) & 0.32 & 0.27 & 0.39 & 0.25 & 0.21 & 0.30 & 0.33 & 0.27 & 0.39 & 0.30 & 0.25 & 0.36 \\
\hline Aluminum, total (ton/yr) & 2.98 & 1.74 & 4.80 & 1.98 & 1.17 & 3.13 & 2.45 & 1.50 & 3.78 & 2.47 & 1.47 & 3.90 \\
\hline Antimony, dissolved (lb/yr) & 784 & 618 & 981 & 673 & 517 & 862 & 720 & 566 & 902 & 726 & 567 & 915 \\
\hline Antimony, total (lb/yr) & 815 & 641 & 1020 & 682 & 524 & 873 & 743 & 586 & 929 & 747 & 584 & 941 \\
\hline Manganese, dissolved (lb/yr) & 763 & 669 & 867 & 701 & 619 & 790 & 735 & 647 & 832 & 733 & 645 & 830 \\
\hline Lead, dissolved (lb/yr) & 2.44 & 1.79 & 3.25 & 1.73 & 1.29 & 2.26 & 2.26 & 1.65 & 3.01 & 2.14 & 1.58 & 2.84 \\
\hline Lead, total (lb/yr) & 23.2 & 2.15 & 97.3 & 20.0 & 1.63 & 87.7 & 11.7 & 3.17 & 31.0 & 18.3 & 2.32 & 72.0 \\
\hline Aluminum, dissolved (ton/yr) & 0.95 & 0.77 & 1.16 & 0.57 & 0.47 & 0.69 & 0.89 & 0.71 & 1.09 & 0.80 & 0.65 & 0.98 \\
\hline Aluminum, total (ton/yr) & 12.8 & 5.26 & 26.2 & 9.97 & 3.45 & 22.8 & 7.75 & 4.17 & 13.2 & 10.2 & 4.29 & 20.8 \\
\hline Suspended sediment (ton/yr) & 1,100 & 342 & 2,670 & 545 & 222 & 1,130 & 835 & 347 & 1,700 & 825 & 304 & 1,830 \\
\hline Fine sediment (ton/yr) & 339 & 120 & 767 & 174 & 76 & 343 & 223 & 103 & 422 & 245 & 100 & 511 \\
\hline Coarse sediment (ton/yr) & 657 & 257 & 1,400 & 349 & 135 & 745 & 568 & 216 & 1,230 & 525 & 203 & 1,120 \\
\hline
\end{tabular}


Table 4. Estimated annual loads of selected trace elements and suspended sediment at five streamflow and water-quality monitoring sites in the Stibnite mining area, central Idaho, 2012-14. - Continued

[Site names and locations are shown in table 1 and figure 1, respectively. Abbreviations: L95, lower 95 percent confidence interval; U95, upper 95 percent confidence interval; $\mathrm{lb} / \mathrm{yr}$, pound per year; ton/yr, ton per year]

\begin{tabular}{|c|c|c|c|c|c|c|c|c|c|c|c|c|}
\hline \multirow{3}{*}{ Constituent } & \multicolumn{12}{|c|}{ Water year } \\
\hline & \multicolumn{3}{|c|}{2012} & \multicolumn{3}{|c|}{2013} & \multicolumn{3}{|c|}{2014} & \multicolumn{3}{|c|}{ 2012-14 mean } \\
\hline & $\begin{array}{c}\text { Annual } \\
\text { load }\end{array}$ & L95 & U95 & $\begin{array}{c}\text { Annual } \\
\text { load }\end{array}$ & L95 & U95 & $\begin{array}{c}\text { Annual } \\
\text { load }\end{array}$ & L95 & U95 & $\begin{array}{c}\text { Annual } \\
\text { load }\end{array}$ & L95 & U95 \\
\hline \multicolumn{13}{|c|}{ Site 4} \\
\hline Arsenic, dissolved (lb/yr) & 3,520 & 3,150 & 3,910 & 3,070 & 2,740 & 3,430 & 3,380 & 3,030 & 3,760 & 3,320 & 2,970 & 3,700 \\
\hline Antimony, dissolved (lb/yr) & 2,050 & 1,690 & 2,460 & 1,750 & 1,410 & 2,150 & 1,940 & 1,600 & 2,330 & 1,910 & 1,570 & 2,310 \\
\hline Antimony, total (lb/yr) & 1,910 & 1,600 & 2,270 & 1,560 & 1,300 & 1,850 & 1,810 & 1,510 & 2,150 & 1,760 & 1,470 & 2,090 \\
\hline Manganese, dissolved (lb/yr) & 1,410 & 1,260 & 1,570 & 1,280 & 1,140 & 1,430 & 1,370 & 1,220 & 1,520 & 1,350 & 1,210 & 1,510 \\
\hline Lead, dissolved (lb/yr) & 3.11 & 2.11 & 4.44 & 2.25 & 1.55 & 3.15 & 2.89 & 1.96 & 4.12 & 2.75 & 1.87 & 3.90 \\
\hline Lead, total (lb/yr) & 11.0 & 6.77 & 16.9 & 6.52 & 4.09 & 9.90 & 10.4 & 6.16 & 16.5 & 9.30 & 5.67 & 14.4 \\
\hline Aluminum, dissolved (ton/yr) & 1.03 & 0.76 & 1.36 & 0.64 & 0.48 & 0.84 & 0.96 & 0.70 & 1.28 & 0.88 & 0.65 & 1.16 \\
\hline Mercury, total (lb/yr) & 0.85 & 0.59 & 1.19 & 0.51 & 0.36 & 0.70 & 0.87 & 0.58 & 1.25 & 0.74 & 0.51 & 1.05 \\
\hline \multicolumn{13}{|c|}{ Site 5} \\
\hline Arsenic, dissolved (lb/yr) & 568 & 511 & 629 & 477 & 425 & 534 & 545 & 492 & 602 & 530 & 476 & 588 \\
\hline Arsenic, total (lb/yr) & 597 & 469 & 753 & 552 & 481 & 630 & 644 & 564 & 732 & 598 & 505 & 705 \\
\hline Antimony, dissolved (lb/yr) & 176 & 143 & 214 & 158 & 126 & 195 & 169 & 138 & 205 & 168 & 136 & 205 \\
\hline Antimony, total (lb/yr) & 166 & 109 & 244 & 150 & 121 & 185 & 162 & 133 & 196 & 159 & 121 & 208 \\
\hline Manganese, dissolved (lb/yr) & 112 & 69.8 & 171 & 88.5 & 56.0 & 133 & 123 & 69.3 & 202 & 108 & 65.0 & 169 \\
\hline Lead, dissolved (lb/yr) & 2.30 & 1.84 & 2.84 & 1.68 & 1.34 & 2.09 & 2.25 & 1.77 & 2.82 & 2.08 & 1.65 & 2.58 \\
\hline Lead, total (lb/yr) & 8.60 & 2.35 & 22.7 & 8.33 & 2.16 & 22.5 & 14.1 & 4.50 & 33.8 & 10.3 & 3.00 & 26.3 \\
\hline Aluminum, dissolved (ton/yr) & 0.69 & 0.48 & 0.95 & 0.45 & 0.31 & 0.62 & 0.73 & 0.50 & 1.02 & 0.62 & 0.43 & 0.86 \\
\hline
\end{tabular}


Table 5. Estimated streamflow-weighted concentrations of selected constituents at five streamflow and water-quality monitoring sites in the Stibnite mining area, central Idaho, 2012-14.

[Site names and locations are shown in table 1 and figure 1, respectively. Abbreviations: FWC, streamflow-weighted concentration; L95, lower 95-percent confidence interval; U95, upper 95-percent confidence interval; $\mu \mathrm{g} / \mathrm{L}$, microgram per liter; $\mathrm{mg} / \mathrm{L}$, milligram per liter]

\begin{tabular}{|c|c|c|c|c|c|c|c|c|c|c|c|c|}
\hline \multirow{3}{*}{ Constituent } & \multicolumn{12}{|c|}{ Water years } \\
\hline & \multicolumn{3}{|c|}{2012} & \multicolumn{3}{|c|}{2013} & \multicolumn{3}{|c|}{2014} & \multicolumn{3}{|c|}{ 2012-14 mean } \\
\hline & FWC & L95 & U95 & FWC & L95 & U95 & FWC & L95 & U95 & FWC & L95 & U95 \\
\hline \multicolumn{13}{|c|}{ Site 1} \\
\hline Arsenic, dissolved $(\mu \mathrm{g} / \mathrm{L})$ & 8.11 & 7.58 & 8.66 & 8.59 & 8.01 & 9.20 & 8.25 & 7.71 & 8.83 & 8.32 & 7.77 & 8.90 \\
\hline Arsenic, total $(\mu \mathrm{g} / \mathrm{L})$ & 8.48 & 7.82 & 9.19 & 8.82 & 8.12 & 9.57 & 8.58 & 7.90 & 9.29 & 8.63 & 7.95 & 9.35 \\
\hline Antimony, dissolved $(\mu \mathrm{g} / \mathrm{L})$ & 0.95 & 0.85 & 1.06 & 1.00 & 0.88 & 1.12 & 0.94 & 0.83 & 1.05 & 0.96 & 0.85 & 1.08 \\
\hline Antimony, total $(\mu \mathrm{g} / \mathrm{L})$ & 0.90 & 0.79 & 1.01 & 0.94 & 0.83 & 1.07 & 0.90 & 0.80 & 1.02 & 0.92 & 0.80 & 1.04 \\
\hline Manganese, dissolved $(\mu \mathrm{g} / \mathrm{L})$ & 1.59 & 1.07 & 2.27 & 1.52 & 1.03 & 2.16 & 1.59 & 1.06 & 2.29 & 1.56 & 1.05 & 2.24 \\
\hline Lead, dissolved $(\mu \mathrm{g} / \mathrm{L})$ & \multirow{2}{*}{\multicolumn{12}{|c|}{$\begin{array}{l}\text { no suitable LOADEST model } \\
\text { no suitable LOADEST model }\end{array}$}} \\
\hline Lead, total $(\mu \mathrm{g} / \mathrm{L})$ & & & & & & & & & & & & \\
\hline Aluminum, dissolved $(\mu \mathrm{g} / \mathrm{L})$ & 25.9 & 19.8 & 33.3 & 23.5 & 17.7 & 30.6 & 25.7 & 19.3 & 33.5 & 25.0 & 18.9 & 32.5 \\
\hline Aluminum, total $(\mu \mathrm{g} / \mathrm{L})$ & 112 & 86.4 & 143 & 111 & 82.9 & 147 & 110 & 81.8 & 145 & 111 & 83.7 & 145 \\
\hline Suspended sediment (mg/L) & 7.51 & 5.57 & 9.91 & 7.63 & 5.38 & 10.51 & 6.96 & 5.04 & 9.39 & 7.37 & 5.33 & 9.93 \\
\hline Fine sediment $(\mathrm{mg} / \mathrm{L})$ & 2.56 & 1.90 & 3.37 & 2.63 & 1.84 & 3.65 & 2.32 & 1.70 & 3.08 & 2.50 & 1.81 & 3.37 \\
\hline Coarse sediment (mg/L) & 5.01 & 3.03 & 7.80 & 5.10 & 2.80 & 8.56 & 4.65 & 2.67 & 7.56 & 4.92 & 2.83 & 7.97 \\
\hline \multicolumn{13}{|c|}{ Site 2} \\
\hline Arsenic, dissolved $(\mu \mathrm{g} / \mathrm{L})$ & 0.92 & 0.88 & 0.96 & 0.96 & 0.92 & 1.00 & 0.92 & 0.88 & 0.96 & 0.93 & 0.89 & 0.97 \\
\hline Arsenic, total $(\mu \mathrm{g} / \mathrm{L})$ & 1.39 & 1.19 & 1.62 & 1.35 & 1.16 & 1.57 & 1.41 & 1.20 & 1.65 & 1.38 & 1.18 & 1.61 \\
\hline Antimony, dissolved $(\mu \mathrm{g} / \mathrm{L})$ & 0.38 & 0.34 & 0.42 & 0.38 & 0.34 & 0.43 & 0.38 & 0.34 & 0.42 & 0.38 & 0.34 & 0.42 \\
\hline Antimony, total $(\mu \mathrm{g} / \mathrm{L})$ & 0.36 & 0.31 & 0.43 & 0.35 & 0.30 & 0.42 & 0.36 & 0.31 & 0.43 & 0.36 & 0.30 & 0.43 \\
\hline Manganese, dissolved $(\mu \mathrm{g} / \mathrm{L})$ & 2.11 & 1.56 & 2.80 & 2.16 & 1.63 & 2.81 & 2.12 & 1.57 & 2.80 & 2.13 & 1.59 & 2.80 \\
\hline Lead, dissolved $(\mu \mathrm{g} / \mathrm{L})$ & \multirow{2}{*}{\multicolumn{12}{|c|}{$\begin{array}{l}\text { no suitable LOADEST model } \\
\text { no suitable LOADEST model }\end{array}$}} \\
\hline Lead, total $(\mu \mathrm{g} / \mathrm{L})$ & & & & & & & & & & & & \\
\hline Aluminum, dissolved $(\mu \mathrm{g} / \mathrm{L})$ & 27.9 & 23.1 & 33.4 & 26.3 & 21.9 & 31.4 & 27.6 & 22.8 & 33.0 & 27.2 & 22.6 & 32.6 \\
\hline Aluminum, total $(\mu \mathrm{g} / \mathrm{L})$ & 258 & 150 & 414 & 208 & 124 & 329 & 206 & 126 & 318 & 224 & 133 & 354 \\
\hline Suspended sediment (mg/L) & 11.8 & 6.10 & 20.7 & 7.23 & 4.33 & 11.4 & 9.64 & 5.22 & 16.3 & 9.55 & 5.22 & 16.1 \\
\hline Fine sediment $(\mathrm{mg} / \mathrm{L})$ & 5.45 & 2.34 & 10.91 & 3.25 & 1.69 & 5.68 & 4.32 & 1.92 & 8.43 & 4.34 & 1.98 & 8.34 \\
\hline Coarse sediment (mg/L) & 6.22 & 3.24 & 10.86 & 4.04 & 2.37 & 6.46 & 5.20 & 2.87 & 8.69 & 5.15 & 2.83 & 8.67 \\
\hline \multicolumn{13}{|c|}{ Site 3} \\
\hline Arsenic, dissolved $(\mu \mathrm{g} / \mathrm{L})$ & 21.0 & 18.7 & 23.4 & 23.7 & 20.9 & 26.9 & 21.4 & 19.1 & 24.0 & 22.1 & 19.6 & 24.8 \\
\hline Arsenic, total $(\mu \mathrm{g} / \mathrm{L})$ & 22.1 & 19.3 & 25.3 & 23.9 & 20.9 & 27.2 & 22.4 & 19.6 & 25.6 & 22.8 & 19.9 & 26.0 \\
\hline Antimony, dissolved $(\mu \mathrm{g} / \mathrm{L})$ & 11.2 & 8.85 & 14.1 & 12.6 & 9.68 & 16.1 & 11.0 & 8.68 & 13.8 & 11.6 & 9.07 & 14.7 \\
\hline Antimony, total $(\mu \mathrm{g} / \mathrm{L})$ & 11.7 & 9.19 & 14.6 & 12.8 & 9.81 & 16.4 & 11.4 & 8.98 & 14.2 & 11.9 & 9.33 & 15.1 \\
\hline Manganese, dissolved $(\mu \mathrm{g} / \mathrm{L})$ & 10.9 & 9.6 & 12.4 & 13.1 & 11.6 & 14.8 & 11.3 & 9.9 & 12.8 & 11.8 & 10.4 & 13.3 \\
\hline Lead, dissolved $(\mu \mathrm{g} / \mathrm{L})$ & 0.03 & 0.03 & 0.05 & 0.03 & 0.02 & 0.04 & 0.03 & 0.03 & 0.05 & 0.03 & 0.03 & 0.05 \\
\hline Lead, total $(\mu \mathrm{g} / \mathrm{L})$ & 0.33 & 0.03 & 1.39 & 0.38 & 0.03 & 1.64 & 0.18 & 0.05 & 0.48 & 0.30 & 0.04 & 1.17 \\
\hline Aluminum, dissolved ( $\mu \mathrm{g} / \mathrm{L})$ & 27.3 & 22.2 & 33.3 & 21.4 & 17.7 & 25.7 & 27.2 & 21.9 & 33.5 & 25.3 & 20.6 & 30.8 \\
\hline Aluminum, total $(\mu \mathrm{g} / \mathrm{L})$ & 366 & 151 & 750 & 373 & 129 & 856 & 238 & 128 & 405 & 326 & 136 & 670 \\
\hline Suspended sediment (mg/L) & 31.4 & 9.80 & 76.4 & 20.4 & 8.32 & 42.2 & 25.6 & 10.65 & 52.2 & 25.8 & 9.59 & 56.9 \\
\hline Fine sediment $(\mathrm{mg} / \mathrm{L})$ & 9.72 & 3.44 & 22.0 & 6.50 & 2.83 & 12.9 & 6.83 & 3.17 & 13.0 & 7.69 & 3.15 & 15.9 \\
\hline Coarse sediment (mg/L) & 18.8 & 7.37 & 39.9 & 13.1 & 5.06 & 27.9 & 17.4 & 6.62 & 37.7 & 16.4 & 6.35 & 35.2 \\
\hline
\end{tabular}


Table 5. Estimated streamflow-weighted concentrations of selected constituents at five streamflow and water-quality monitoring sites in the Stibnite mining area, central Idaho, 2012-14.-Continued

[Site names and locations are shown in table 1 and figure 1, respectively. Abbreviations: FWC, streamflow-weighted concentration; L95, lower 95-percent confidence interval; U95, upper 95-percent confidence interval; $\mu \mathrm{g} / \mathrm{L}$, microgram per liter; $\mathrm{mg} / \mathrm{L}$, milligram per liter]

\begin{tabular}{|c|c|c|c|c|c|c|c|c|c|c|c|c|}
\hline \multirow{3}{*}{ Constituent } & \multicolumn{12}{|c|}{ Water years } \\
\hline & \multicolumn{3}{|c|}{2012} & \multicolumn{3}{|c|}{2013} & \multicolumn{3}{|c|}{2014} & \multicolumn{3}{|c|}{ 2012-14 mean } \\
\hline & FWC & L95 & U95 & FWC & L95 & U95 & FWC & L95 & U95 & FWC & L95 & U95 \\
\hline \multicolumn{13}{|c|}{ Site 4} \\
\hline Arsenic, dissolved $(\mu \mathrm{g} / \mathrm{L})$ & 42.0 & 37.6 & 46.7 & 48.6 & 43.3 & 54.3 & 43.2 & 38.7 & 48.1 & 44.6 & 39.9 & 49.7 \\
\hline Arsenic, total $(\mu \mathrm{g} / \mathrm{L})$ & 45.4 & 39.9 & 51.5 & 51.9 & 45.3 & 59.1 & 46.6 & 40.9 & 52.9 & 48.0 & 42.1 & 54.5 \\
\hline Antimony, dissolved ( $\mu \mathrm{g} / \mathrm{L})$ & 24.5 & 20.2 & 29.4 & 27.7 & 22.3 & 34.0 & 24.8 & 20.4 & 29.7 & 25.6 & 21.0 & 31.0 \\
\hline Antimony, total $(\mu \mathrm{g} / \mathrm{L})$ & 22.8 & 19.1 & 27.1 & 24.6 & 20.6 & 29.3 & 23.1 & 19.3 & 27.4 & 23.5 & 19.7 & 27.9 \\
\hline Manganese, dissolved $(\mu \mathrm{g} / \mathrm{L})$ & 16.8 & 15.1 & 18.7 & 20.3 & 18.1 & 22.7 & 17.5 & 15.6 & 19.5 & 18.2 & 16.3 & 20.3 \\
\hline Lead, dissolved $(\mu \mathrm{g} / \mathrm{L})$ & 0.04 & 0.03 & 0.05 & 0.04 & 0.02 & 0.05 & 0.04 & 0.02 & 0.05 & 0.04 & 0.02 & 0.05 \\
\hline Lead, total $(\mu \mathrm{g} / \mathrm{L})$ & 0.13 & 0.08 & 0.20 & 0.10 & 0.06 & 0.16 & 0.13 & 0.08 & 0.21 & 0.12 & 0.07 & 0.19 \\
\hline Aluminum, dissolved $(\mu \mathrm{g} / \mathrm{L})$ & 24.6 & 18.1 & 32.6 & 20.4 & 15.3 & 26.6 & 24.4 & 17.8 & 32.7 & 23.1 & 17.1 & 30.6 \\
\hline Aluminum, total $(\mu \mathrm{g} / \mathrm{L})$ & 185 & 93.8 & 329 & 149 & 77.4 & 260 & 184 & 90.9 & 335 & 173 & 87.4 & 308 \\
\hline Suspended sediment (mg/L) & 6.78 & 3.86 & 11.1 & 5.53 & 3.27 & 8.77 & 7.45 & 3.89 & 13.0 & 6.59 & 3.67 & 10.9 \\
\hline Fine sediment $(\mathrm{mg} / \mathrm{L})$ & 5.48 & 2.89 & 9.49 & 4.42 & 2.42 & 7.43 & 5.89 & 2.84 & 10.9 & 5.26 & 2.71 & 9.27 \\
\hline Coarse sediment (mg/L) & 1.48 & 0.79 & 2.54 & 1.14 & 0.69 & 1.79 & 1.49 & 0.85 & 2.45 & 1.37 & 0.77 & 2.26 \\
\hline Mercury (total) $(\mu \mathrm{g} / \mathrm{L})$ & 0.010 & 0.007 & 0.014 & 0.008 & 0.006 & 0.011 & 0.011 & 0.007 & 0.016 & 0.010 & 0.007 & 0.014 \\
\hline \multicolumn{13}{|c|}{ Site 5} \\
\hline Arsenic, dissolved $(\mu \mathrm{g} / \mathrm{L})$ & 11.2 & 10.1 & 12.4 & 12.1 & 10.8 & 13.5 & 10.9 & 9.9 & 12.1 & 11.4 & 10.2 & 12.7 \\
\hline Arsenic, total $(\mu \mathrm{g} / \mathrm{L})$ & 11.8 & 9.27 & 14.9 & 14.0 & 12.2 & 16.0 & 12.9 & 11.3 & 14.7 & 12.9 & 10.9 & 15.2 \\
\hline Antimony, dissolved $(\mu \mathrm{g} / \mathrm{L})$ & 3.48 & 2.83 & 4.23 & 4.00 & 3.20 & 4.95 & 3.38 & 2.76 & 4.11 & 3.62 & 2.93 & 4.43 \\
\hline Antimony, total $(\mu \mathrm{g} / \mathrm{L})$ & 3.27 & 2.16 & 4.82 & 3.80 & 3.05 & 4.68 & 3.26 & 2.67 & 3.94 & 3.45 & 2.63 & 4.48 \\
\hline Manganese, dissolved $(\mu \mathrm{g} / \mathrm{L})$ & 2.21 & 1.38 & 3.37 & 2.24 & 1.42 & 3.37 & 2.47 & 1.39 & 4.06 & 2.31 & 1.40 & 3.60 \\
\hline Lead, dissolved $(\mu \mathrm{g} / \mathrm{L})$ & 0.05 & 0.04 & 0.06 & 0.04 & 0.03 & 0.05 & 0.05 & 0.04 & 0.06 & 0.04 & 0.04 & 0.06 \\
\hline Lead, total $(\mu \mathrm{g} / \mathrm{L})$ & 0.17 & 0.05 & 0.45 & 0.21 & 0.05 & 0.57 & 0.28 & 0.09 & 0.68 & 0.22 & 0.06 & 0.57 \\
\hline Aluminum, dissolved $(\mu \mathrm{g} / \mathrm{L})$ & 16.5 & 11.6 & 22.7 & 14.2 & 9.91 & 19.7 & 18.6 & 12.8 & 26.1 & 16.4 & 11.4 & 22.8 \\
\hline Aluminum, total $(\mu \mathrm{g} / \mathrm{L})$ & 179 & 68.7 & 383 & 146 & 47.83 & 346 & 263 & 79.7 & 651 & 196 & 65.4 & 460 \\
\hline Suspended sediment (mg/L) & 15.0 & 8.07 & 25.4 & 12.9 & 5.98 & 24.6 & 24.6 & 10.7 & 48.5 & 17.5 & 8.26 & 32.8 \\
\hline Fine sediment $(\mathrm{mg} / \mathrm{L})$ & 3.63 & 1.72 & 6.85 & 6.53 & 2.51 & 14.0 & 6.72 & 3.40 & 12.0 & 5.63 & 2.54 & 11.0 \\
\hline Coarse sediment (mg/L) & 8.80 & 4.16 & 16.4 & 9.49 & 2.96 & 23.1 & 11.6 & 4.55 & 24.7 & 9.98 & 3.89 & 21.4 \\
\hline Mercury (total) $(\mu \mathrm{g} / \mathrm{L})$ & 0.57 & 0.17 & 1.43 & 1.57 & 0.26 & 5.30 & 0.83 & 0.20 & 2.33 & 0.99 & 0.21 & 3.02 \\
\hline
\end{tabular}



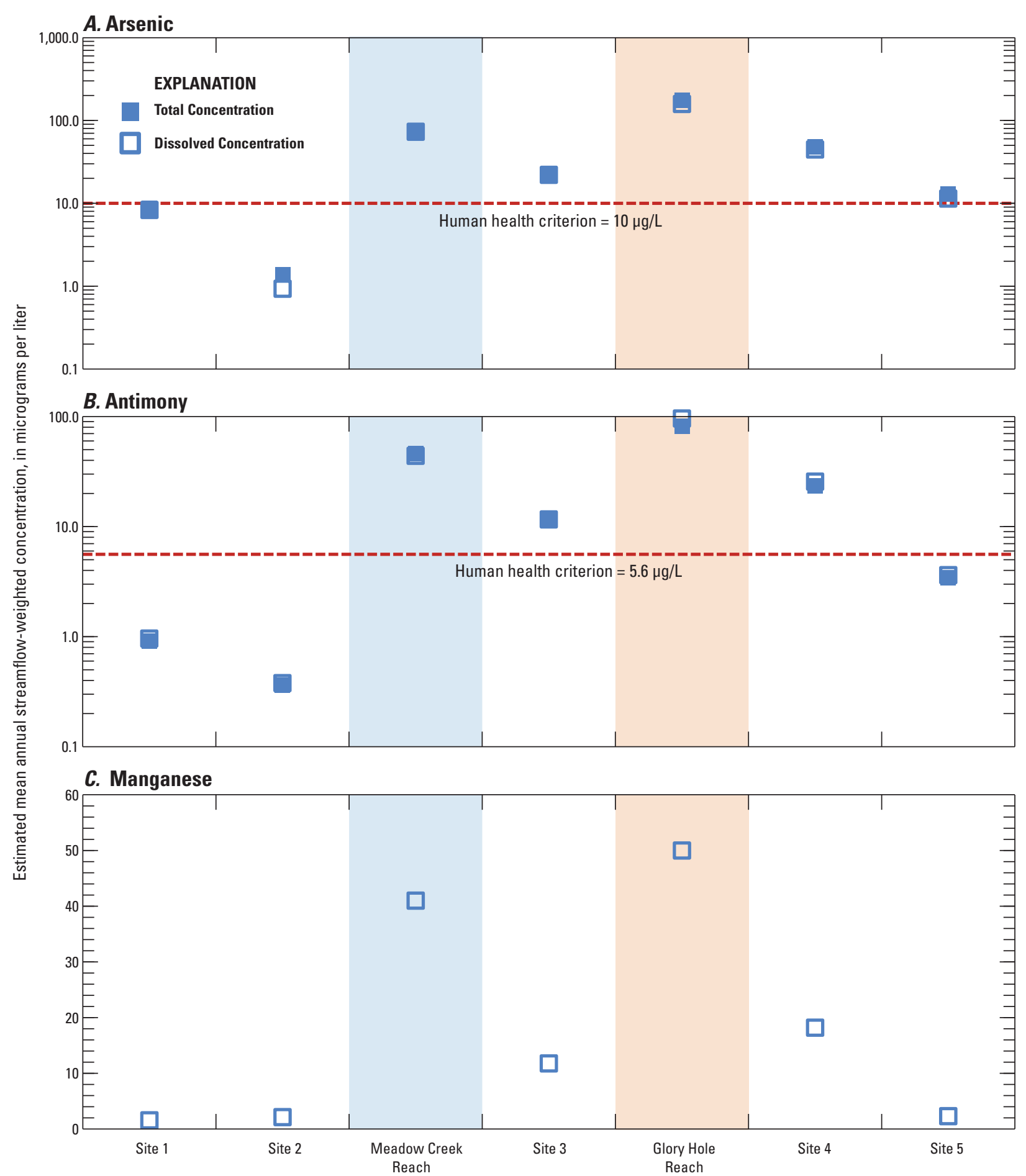

Figure 11. Estimated mean annual streamflow-weighted concentrations of $(A)$ arsenic, $(B)$ antimony, and $(C)$ manganese in streams in the Stibnite mining area, central Idaho, 2012-14. Site names and locations are shown in table 1 and figure 1, respectively. 
Table 6. Substantial sources of arsenic and antimony identified at selected sites along Meadow Creek, Stibnite mining area, central Idaho, September 22, 2011.

[Site locations are shown in figure 12. Blowout Creek is officially named East Fork Meadow Creek in figure 1. Abbreviations: $\mu$ g/L, microgram per liter; $\mathrm{lb} / \mathrm{d}$, pound per day; $\mathrm{m}$, meter]

\begin{tabular}{|c|c|c|c|c|c|}
\hline Site No. & Site name & Streamflow & \multicolumn{3}{|c|}{ Dissolved antimony } \\
\hline 4453251152046 & Meadow Creek inflow, $280 \mathrm{~m}$ upstream of bend in road & 0.095 & 173 & 8.86E-2 & 390 \\
\hline 4453441152021 & Blowout Creek at Meadow Creek & 1.94 & 1.30 & $1.36 \mathrm{E}-2$ & 13 \\
\hline \multirow[t]{2}{*}{4453461152017} & Meadow Creek inflow, near runway entrance & 0.054 & 269 & $7.84 \mathrm{E}-2$ & 57 \\
\hline & & \multicolumn{3}{|c|}{ Dissolved arsenic } & \\
\hline Site No. & Site name & $\begin{array}{c}\text { Concentration } \\
(\mu \mathrm{g} / \mathrm{L})\end{array}$ & $\begin{array}{c}\text { Instantaneous } \\
\text { load } \\
(\mathrm{lb} / \mathrm{d})\end{array}$ & $\begin{array}{l}\text { Increase in loa } \\
\text { relative to } \\
\text { adjacent } \\
\text { upstream site } \\
\text { (percent) }\end{array}$ & \\
\hline 4453251152046 & Meadow Creek inflow, $280 \mathrm{~m}$ upstream of bend in road & 1,340 & 6.87E-1 & 257 & \\
\hline 4453261152043 & Meadow Creek inflow, $240 \mathrm{~m}$ upstream of bend in road & 21.4 & 1.64E-2 & 2.7 & \\
\hline 4453391152029 & Meadow Creek inflow, below extent of cascading section & 526 & $2.98 \mathrm{E}-1$ & 36 & \\
\hline 4453441152021 & Blowout Creek at Meadow Creek & 7.32 & 7.66E-2 & 7.0 & \\
\hline 4453461152017 & Meadow Creek inflow, near runway entrance & 1,300 & 3.79E-1 & 29 & \\
\hline
\end{tabular}




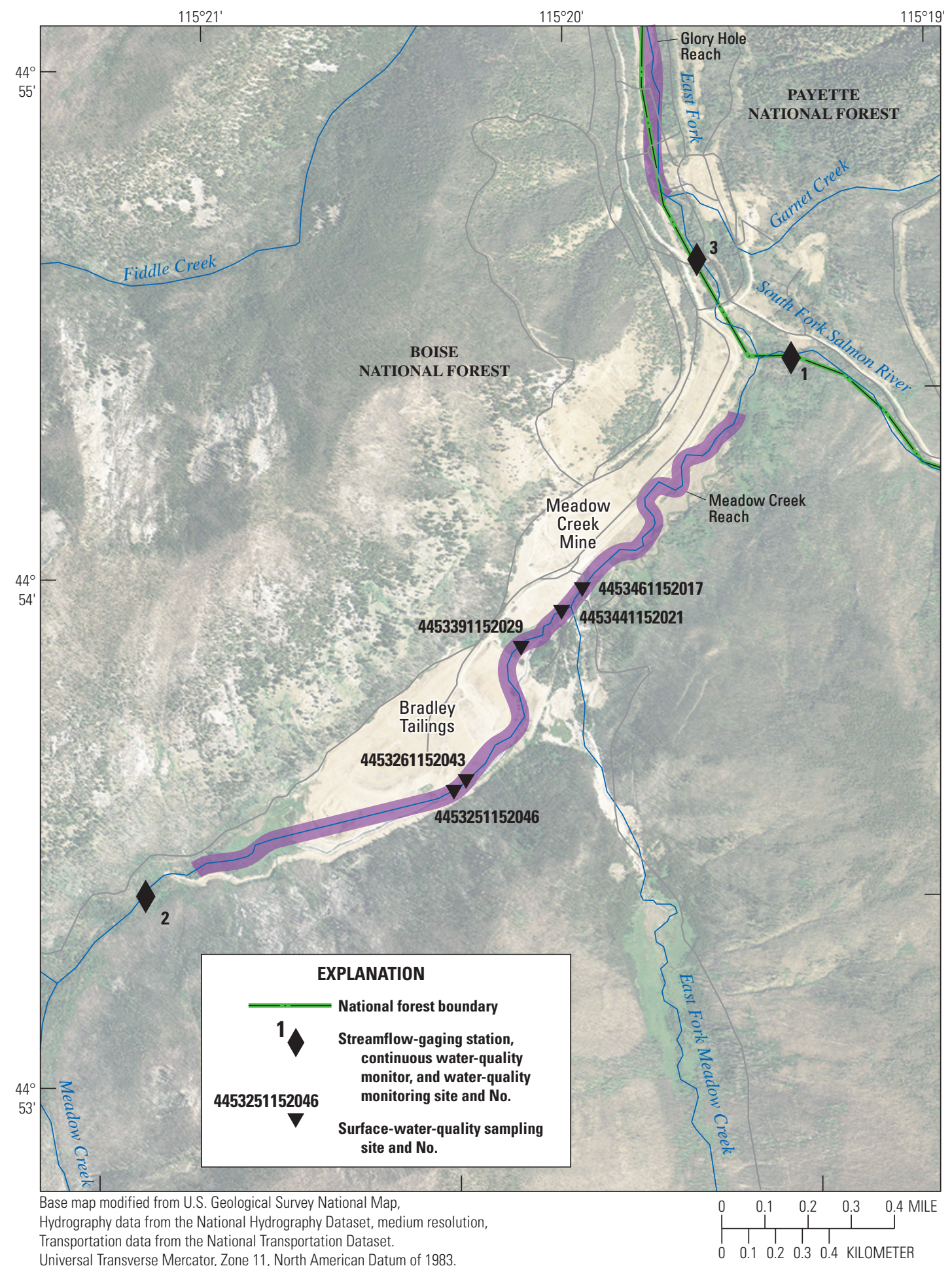

Figure 12. Locations of substantial sources of arsenic and antimony identified along Meadow Creek, Stibnite mining area, central Idaho, September 22, 2011. 


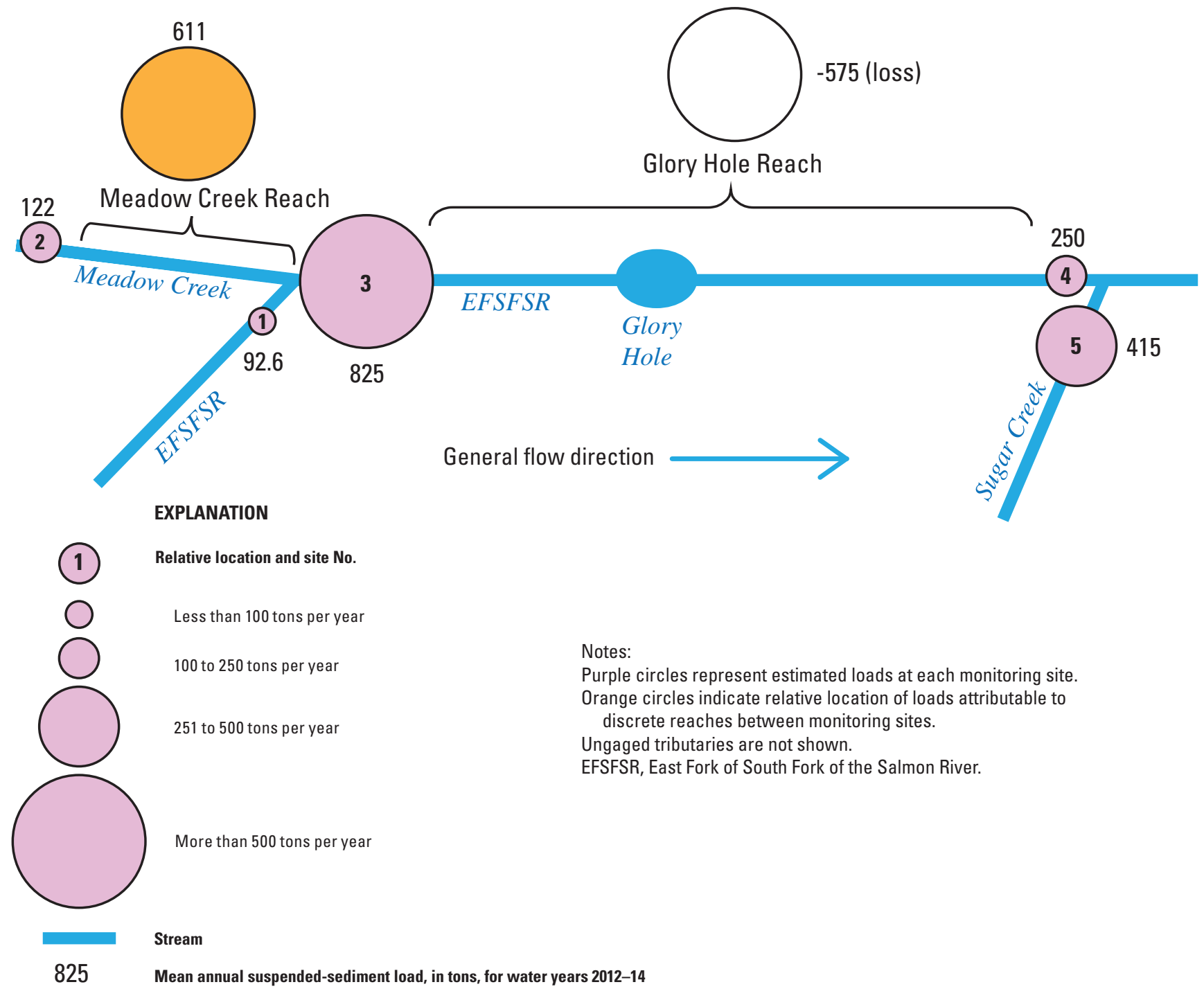

Figure 13. Estimated mean annual suspended sediment loads at monitoring sites in the Stibnite mining area, central Idaho, 2012-14. Site names and locations are shown in table 1 and figure 1, respectively. 


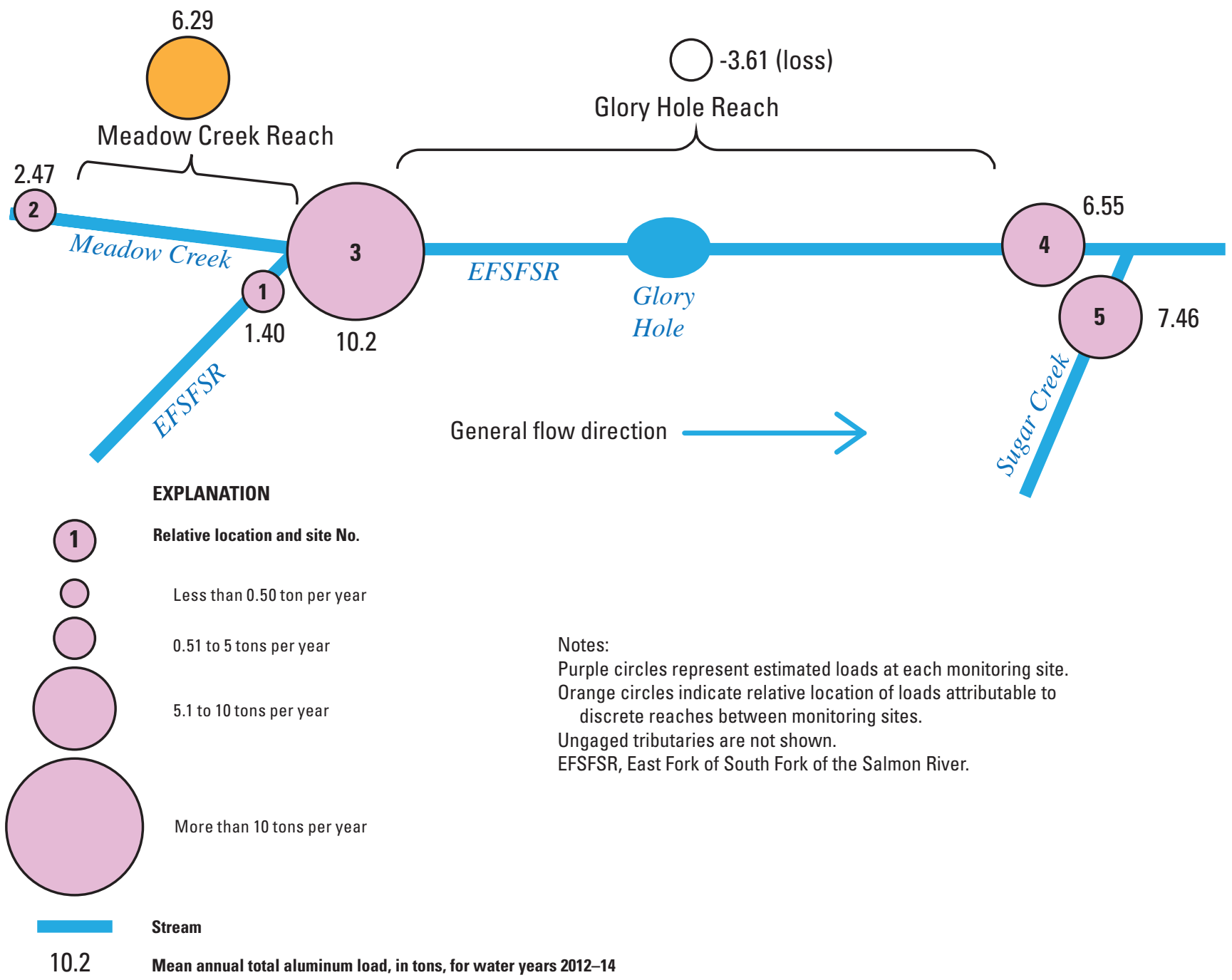

Figure 14. Estimated mean annual total aluminum loads at monitoring sites in the Stibnite mining area, central Idaho, 2012-14. Site names and locations are shown in table 1 and figure 1, respectively. 


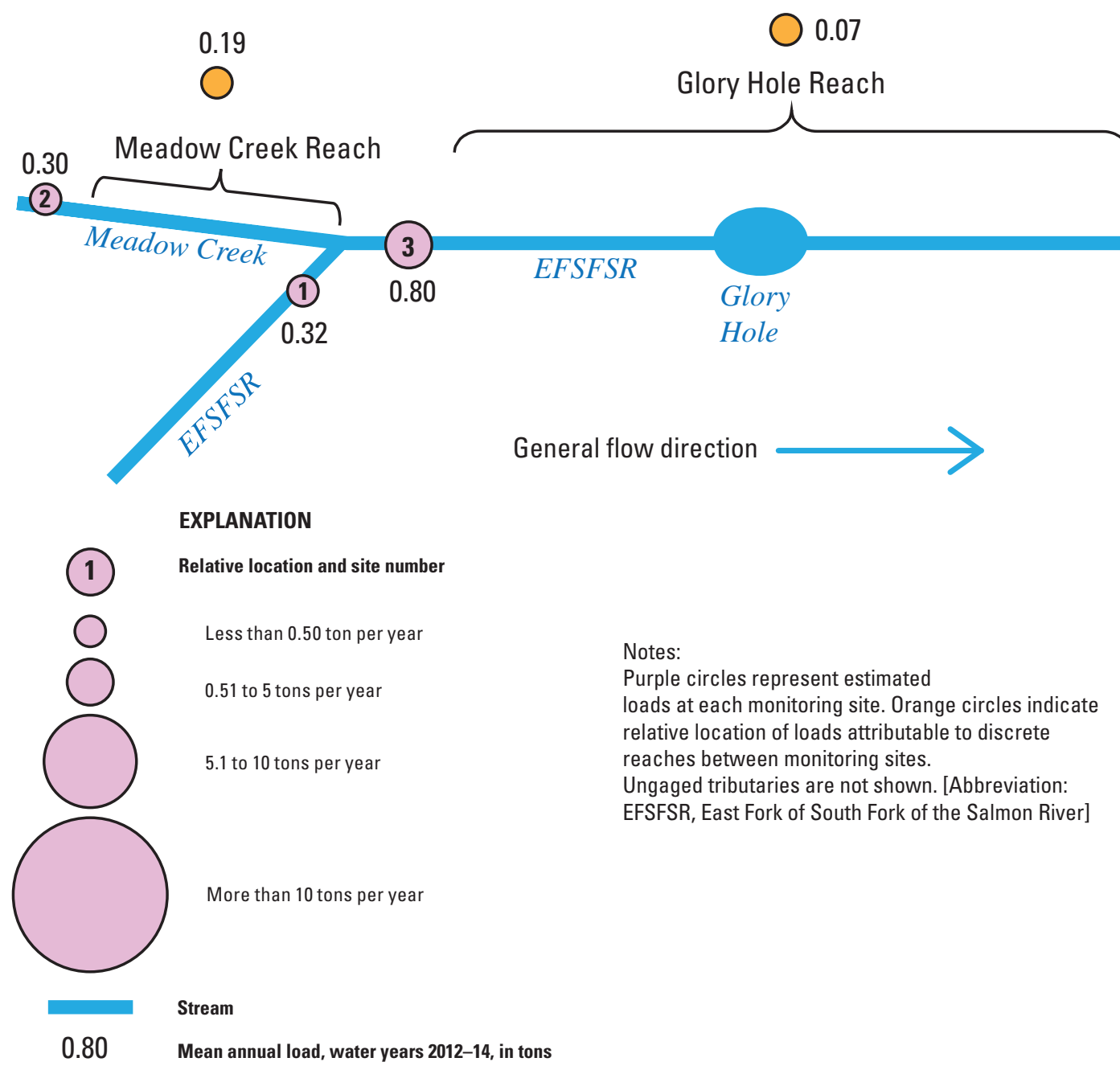

Figure 15. Estimated mean annual dissolved aluminum loads at monitoring sites in the Stibnite mining area, central Idaho, 2012-14. Site names and locations are shown in table 1 and figure 1, respectively. 



Figure 16. Estimated mean annual streamflow-weighted concentrations of $(A)$ aluminum, $(B)$ lead, and $(C)$ suspended sediment at monitoring sites in the Stibnite mining area, central Idaho, 2012-14. Site names and locations are shown in table 1 and figure 1, respectively. 
Loading and transport of total aluminum and total lead were similar to the loading and transport of suspended sediment. On average, the estimated annual total aluminum load in Sugar Creek (site 5) was about 1 ton higher than the annual total aluminum load discharged from the Meadow Creek reach. As compared to the EFSFSR at site 4, Sugar Creek (site 5) accounted for a slightly larger amount of the total aluminum load transported downstream of the study area (fig. 14). The estimated mean annual FWC of total aluminum in sources to the Meadow Creek reach was 4 times as high as the mean annual FWC of total aluminum in Sugar Creek at site 5, suggesting that the East Fork Meadow Creek is a concentrated source of total aluminum (fig. 16). With the exception of the East Fork Meadow Creek, total aluminum was not measured in the inflows shown in table 6 during intensive sampling in the Meadow Creek reach on September 22, 2011. However, the total aluminum concentration in the East Fork Meadow Creek was $53 \mu \mathrm{g} / \mathrm{L}$, compared to an average concentration of $21 \mu \mathrm{g} / \mathrm{L}$ measured in Meadow Creek upstream of East Fork Meadow Creek on September 22, 2011. The total aluminum load in Meadow Creek doubled as a result of the total aluminum source from East Fork Meadow Creek and did not substantially increase in any additional samples collected downstream of East Fork Meadow Creek on September 22, 2011. Results from all samples collected along Meadow Creek on September 22, 2011, are available from the USGS National Water Information System (U.S. Geological Survey, 2015).

Because detections of total and dissolved lead were infrequent at sites 1 and 2, loads for lead upstream of site 3 were not estimated. About one-half of the total lead and one third of the total aluminum loads at site 3 were deposited in the Glory Hole (table 4, fig. 14). FWCs of total lead and total aluminum at site 3 were twice as high as those at site 4 because of losses of total lead and total aluminum loads in the Glory Hole (fig. 16). The mean annual load of total lead for 2012-14 at site 4 was $9.30 \mathrm{lb} / \mathrm{yr}$ compared to

$10.3 \mathrm{lb} / \mathrm{yr}$ at site 5 (Sugar Creek), suggesting that Sugar Creek contributes more than one-half of the total lead transported downstream of the study area in the EFSFSR (table 4).

Dissolved FWCs of lead and aluminum changed little from upstream to downstream, with the largest sources attributable to background loads at sites 1, 2, and 5 (tables 4 and 5; figs. 7 , 15, and 16).

A limited number of samples and (or) detections of total mercury prevented the use of load models to estimate annual FWCs and loads of total mercury at sites 1-3. Total mercury load models for sites 4 and 5 indicate that 98 percent of the mercury load transported downstream of the study area is attributable to Sugar Creek (fig. 7, table 4). Estimated annual FWCs of total mercury were $0.010 \mu \mathrm{g} / \mathrm{L}$ at site 4 on the EFSFWR, which is close to the State of Idaho $0.012-\mu \mathrm{g} / \mathrm{L}$ chronic exposure AWQC. However, the mean annual FWC estimated for total mercury at site 5 on Sugar Creek was $0.99 \mu \mathrm{g} / \mathrm{L}$, nearly two orders of magnitude higher than the FWC at site 4 (table 5).

\section{LOAD ESTimation (LOADEST) Model Results}

Significant correlations $(\mathrm{p}<0.01)$ between streamflow and concentrations of modeled constituents generally resulted in favorable LOADEST models (fig. 6, table 7). Ninety-five percent confidence intervals around estimated mean annual loads and FWCs quantify uncertainty around estimates and generally were larger for constituents with greater variability in measured loads (tables 4 and 5). Recent research has shown that LOADEST models can produce biased estimates of long-term average constituent loads (Stenback and others, 2011; Garrett, 2012; Hirsch, 2014), and LOADEST has since been modified to facilitate residual analysis and bias identification (Runkel, 2013). Long-term bias in model estimates was less of a concern because the modeling period was only 3 years and predictor variables describing trends in time were not used. High model bias often indicated hysteresis in transport of sediment and sediment-associated constituents in the study area. Bias diagnostics described by Runkel (2013) were used as an indication that an additional predictor variable may be necessary to account for hysteresis in constituent transport. Use of a predictor variable describing variation in streamflow frequently resulted in large reductions in overall model bias where hysteresis in constituent transport was evident.

\section{Streamflow Variability and Hysteresis in Particulate Constituent Transport}

Various stream basin characteristics may have affected the significance of a particular streamflow variability term at each site. Moving averages of the previous 1, 3, 7, and 30 days were compared to daily mean streamflow and tested for significance as predictor variables describing particulate constituent transport. The ratio of estimated daily surface runoff in cubic feet per second to daily mean streamflow in cubic feet per second (the base flow index [BFI]) also was tested as a predictor variable to account for hysteresis. A streamflow variability term with a longer daily time-step helps describe the effects of sequential events or prolonged peaks, whereas absolute values of variability terms help describe the degree of flashiness of increased streamflow events (Wang and Linker, 2008). Snowmelt runoff controls particulate constituent transport in the study area, and most samples used to calibrate LOADEST models were collected during snowmelt runoff (fig. 3). 
Table 7. Regression coefficients and coefficients of determination $\left(R^{2}\right)$ for models used to estimate loads of selected constituents at monitoring sites in the Stibnite mining area, central Idaho, 2012-14.

[Site names and locations are shown in table 1 and figure 1, respectively. Each regression model was calibrated using the available data collected at each station for water years 2012-14. The regression equation is $\ln L=I+a(\ln Q)+b\left(\ln Q^{2}\right)+c[\sin (2 \pi T)]+d[\cos (2 \pi T)]+e(S V T)+\varepsilon$, where $\ln$ is the natural logarithm; $L$ is the constituent load, in pounds per day; $I$ is the regression intercept; $Q$ is the centered streamflow, in cubic feet per second; $T$ is the centered decimal time in years from the beginning of the calibration period; $\sin (2 \pi T)$ and $\cos (2 \pi T)$ are periodic time functions that describe seasonal variability; SVT is the term describing streamflow variability; a, b, c, d, and e are regression coefficients that remain constant over time; and $\varepsilon$ is the unaccounted error associated with the regression model. $\mathrm{R}^{2}$ (coefficient of determination) represents the amount of variance explained by the model. Abbreviations: RMSE, root mean square error; lb/d, pound per day; -, no regression coefficient]

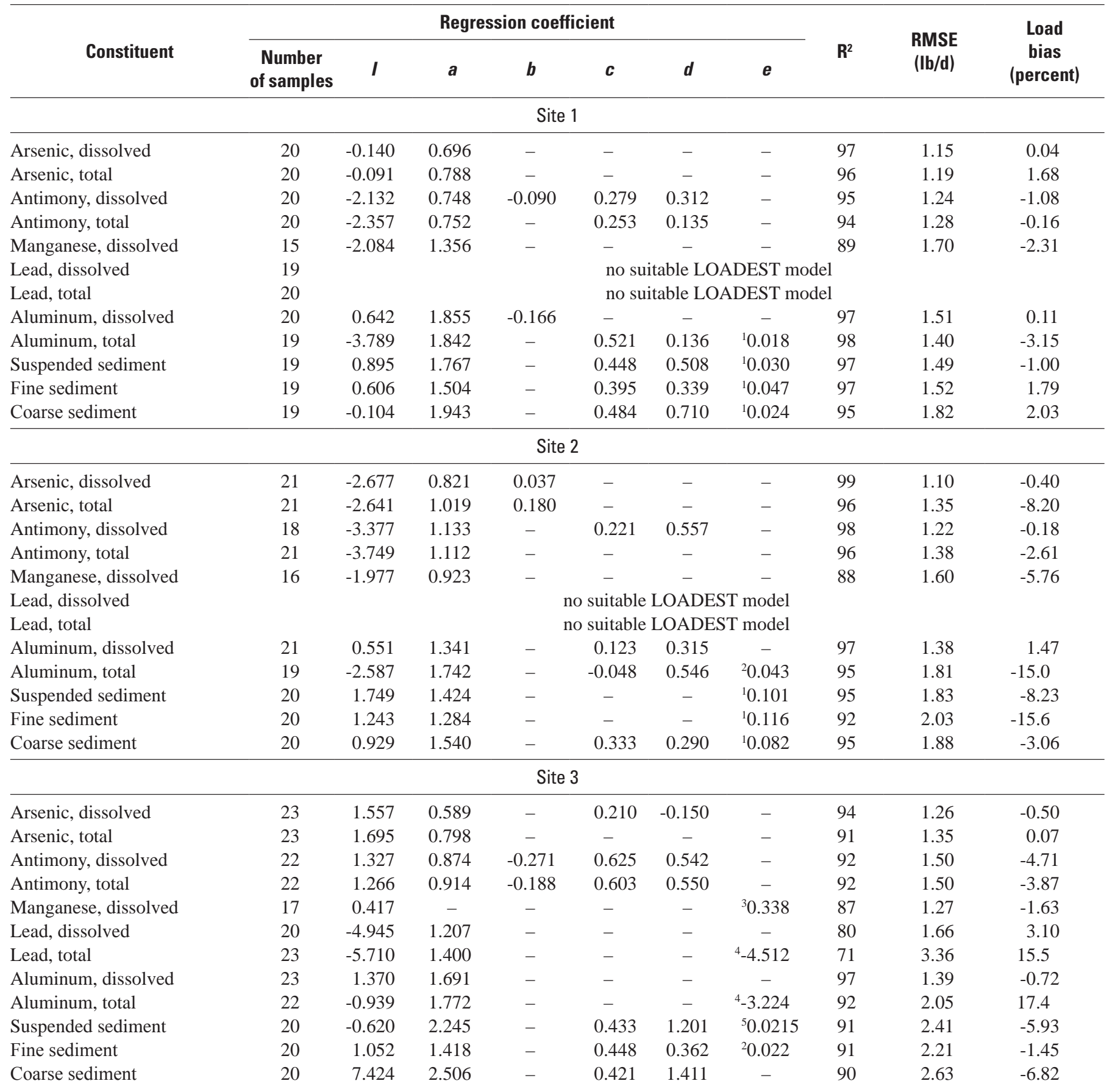


Table 7. Regression coefficients and coefficients of determination $\left(R^{2}\right)$ for models used to estimate loads of selected constituents at monitoring sites in the Stibnite mining area, central Idaho, 2012-14._- Continued

[Site names and locations are shown in table 1 and figure 1, respectively. Each regression model was calibrated using the available data collected at each station for water years 2012-14. The regression equation is $\ln L=I+a(\ln Q)+b\left(\ln Q^{2}\right)+c[\sin (2 \pi T)]+d[\cos (2 \pi T)]+e(S V T)+\varepsilon$, where $\ln$ is the natural logarithm; $\mathrm{L}$ is the constituent load, in pounds per day; I is the regression intercept; $Q$ is the centered streamflow, in cubic feet per second; $T$ is the centered decimal time in years from the beginning of the calibration period; $\sin (2 \pi \mathrm{T})$ and $\cos (2 \pi \mathrm{T})$ are periodic time functions that describe seasonal variability; SVT is the term describing streamflow variability; $a, b, c, d$, and e are regression coefficients that remain constant over time; and $\varepsilon$ is the unaccounted error associated with the regression model. $\mathrm{R}^{2}$ (coefficient of determination) represents the amount of variance explained by the model. Abbreviations: RMSE, root mean square error; $\mathrm{lb} / \mathrm{d}$, pound per day; -, no regression coefficient]

\begin{tabular}{|c|c|c|c|c|c|c|c|c|c|c|}
\hline \multirow[b]{2}{*}{ Constituent } & \multicolumn{7}{|c|}{ Regression coefficient } & \multirow[b]{2}{*}{$\mathbf{R}^{2}$} & \multirow{2}{*}{$\begin{array}{l}\text { RMSE } \\
\text { (lb/d) }\end{array}$} & \multirow{2}{*}{$\begin{array}{c}\text { Load } \\
\text { bias } \\
\text { (percent) }\end{array}$} \\
\hline & $\begin{array}{c}\text { Number } \\
\text { of samples }\end{array}$ & $I$ & $a$ & $\boldsymbol{b}$ & $c$ & $d$ & $e$ & & & \\
\hline Arsenic, dissolved & 22 & 2.514 & 0.575 & - & - & - & - & 89 & 1.27 & 0.49 \\
\hline Arsenic, total & 22 & 2.587 & 0.614 & - & - & - & - & 87 & 1.33 & 0.53 \\
\hline Manganese, dissolved & 16 & 1.717 & 0.467 & -0.133 & - & - & - & 88 & 1.24 & 0.61 \\
\hline Lead, dissolved & 19 & -4.762 & 1.126 & - & - & - & - & 65 & 1.89 & 4.46 \\
\hline Lead, total & 21 & -3.541 & 2.000 & - & -0.545 & 0.620 & - & 88 & 1.94 & -6.36 \\
\hline Aluminum, dissolved & 22 & 1.473 & 1.578 & - & - & - & - & 94 & 1.62 & 2.50 \\
\hline Aluminum, total & 21 & 3.124 & 1.709 & - & - & - & - & 84 & 2.44 & 6.45 \\
\hline \multicolumn{11}{|c|}{ Site 5} \\
\hline Arsenic, dissolved & 21 & 0.862 & 0.796 & - & 0.021 & 0.367 & - & 95 & 1.23 & 0.26 \\
\hline Arsenic, total & 20 & -0.915 & 0.377 & - & - & - & ${ }^{7} 0.015$ & 94 & 1.31 & 4.52 \\
\hline Antimony, dissolved & 20 & -0.358 & 0.587 & - & -0.031 & 0.579 & - & 72 & 1.38 & 1.72 \\
\hline Antimony, total & 19 & -2.288 & 0.483 & - & 0.004 & 0.561 & ${ }^{7} 0.007$ & 84 & 1.37 & -1.30 \\
\hline Manganese, dissolved & 15 & -1.710 & 0.928 & 0.455 & - & - & - & 76 & 1.95 & -7.03 \\
\hline Lead, dissolved & 20 & -9.042 & 1.069 & - & - & - & ${ }^{8} 0.018$ & 88 & 1.04 & 10.0 \\
\hline Lead, total & 20 & -11.347 & 1.776 & - & - & - & ${ }^{7} 0.019$ & 84 & 2.60 & 10.0 \\
\hline Aluminum, dissolved & 21 & 0.815 & 1.780 & - & 0.409 & -0.030 & - & 96 & 1.68 & 3.86 \\
\hline Aluminum, total & 21 & 2.146 & 2.339 & 0.333 & - & - & - & 89 & 2.81 & 9.77 \\
\hline
\end{tabular}

${ }^{1}$ Moving average of streamflow for the previous 3 days compared to each daily streamflow.

${ }^{2}$ Moving average of streamflow for the previous 7 days compared to each daily streamflow.

${ }^{3}$ Absolute value of the moving average of streamflow for the previous 7 days compared to each daily streamflow.

${ }^{4}$ Ratio of estimated daily mean runoff to daily mean streamflow in cubic feet per second (known as the base flow index [BFI]).

${ }^{5}$ Moving average of streamflow for the previous 1 day compared to each daily streamflow.

${ }^{6}$ Absolute value of the moving average of streamflow for the previous 1 day compared to each daily streamflow.

${ }^{7}$ Absolute value of the moving average of streamflow for the previous 30 days compared to each daily streamflow.

${ }^{8}$ Absolute value of the moving average of streamflow for the previous 7 days compared to each daily streamflow. 
The shape of the hydrograph may affect the significance of streamflow terms in the LOADEST models. Sample results from Sugar Creek (site 5) show that the way the snowpack melts affects particulate constituent transport (fig. 3, fig. 17). Snowmelt runoff was similar in 2012 and 2014, with numerous spring increases in the hydrograph as the snowpack melted. In contrast, most of the snowpack melted in one event in 2013, which also produced the highest concentration of mercury in Sugar Creek (site 5) at $26 \mu \mathrm{g} / \mathrm{L}$. Although a sample from Sugar Creek was collected at the peak-of-record streamflow in May 2014, the total mercury concentration was only $2.8 \mu \mathrm{g} / \mathrm{L}$, likely because several smaller-magnitude snowmelt events prior to the 2014 peak had already transported much of the sediment that had accumulated during the winter months of 2013-14 (fig. 17).

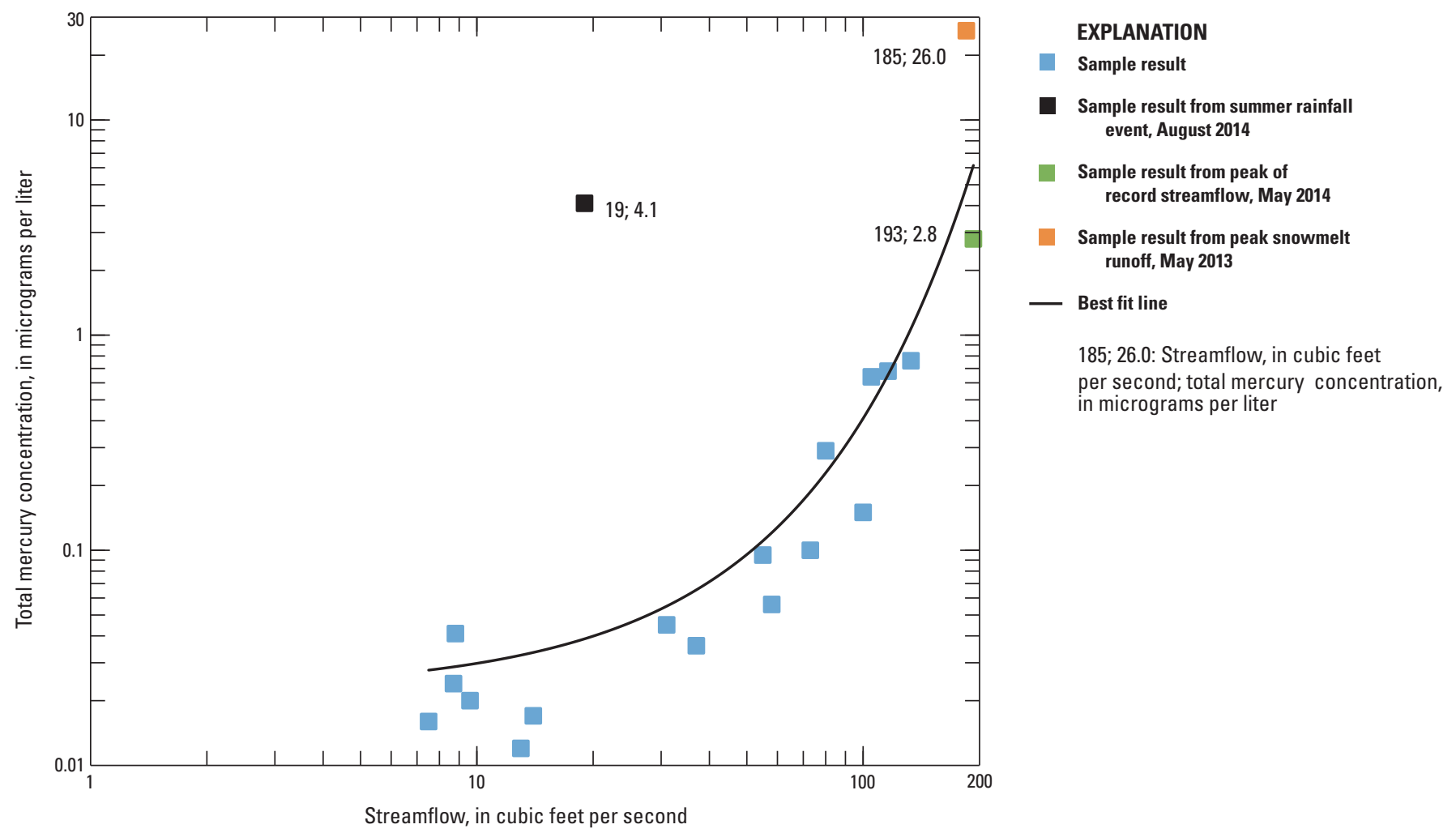

Figure 17. Sampled streamflow and total mercury concentrations in Sugar Creek near Stibnite, central Idaho, 2012-14. 
Runoff and interflow (lateral flow in the unsaturated zone) associated with the first flow-inducing event of the snowmelt season tend to pick up unconsolidated, fine sediment that has accumulated on or just below the land surface and in the stream channel of the watershed (Wang and others, 2010). Because snowpack and snowmelt runoff vary from year to year, simple linear or periodic time functions probably do not adequately characterize hysteresis in constituent transport. Changes in particle-size distribution during prolonged streamflow events also have contributed to hysteresis in sediment and sediment-associated constituent transport (Landers and Sturm, 2013). Changes in sediment source during snowmelt runoff may be affected by antecedent conditions, including air temperature, soil moisture, and ground temperature. Forest fires burned much of the study area in 2000, 2006, and 2007 (fig. 1), and sediment transport in the study area may change as areas become re-vegetated and the sediment sources vary.

Rainfall runoff events occurred each autumn in the study area, and samples were collected during one late-summer rainfall event in August 2014 (fig. 3). Changes in sediment source during rainfall runoff events may be affected by antecedent conditions and also can result from localized mass wasting. The relation between total mercury concentration and streamflow in the sample collected from Sugar Creek in August 2014 was substantially different as compared to all the other samples collected from Sugar Creek (fig. 17), likely because of conditions preceding the August rainfall event. The suspended-sediment concentration in the August 2014 sample was $13 \mathrm{mg} / \mathrm{L}$ and the streamflow was $19 \mathrm{ft}^{3} / \mathrm{s}$. The suspended-sediment concentration in the August 2014 sample was in the range of suspended-sediment concentrations from other samples collected at streamflows between 80 and $133 \mathrm{ft}^{3} / \mathrm{s}$ on the rising or falling limb of the hydrograph during periods of sustained snowmelt runoff. The relatively high sediment and mercury concentration associated with a relatively low flow in August 2014 shows that sediment (and mercury) transport during a rainfall event preceded by a dry period is greater relative to sediment and mercury transport during a period of sustained high flows.

In general, use of the untransformed streamflow (rather than $\ln Q$ ) to generate the streamflow variability term in load models resulted in greater significance of SVT as a predictor variable. Except for site 3, a specific streamflow variability term typically was more significant than other streamflow variability terms tested for significance in load models at a given site (table 7). At sites 1 and 2, which represent the headwaters of EFSFSR and Meadow Creek, a moving average of the previous 3 days compared to the daily mean streamflow generally was most significant as a term to account for hysteresis in constituent transport (table 7). Streamflow variability terms generally were insignificant in load models developed for site 4 (downstream of the Glory Hole), likely because most sediment and sediment-associated constituents were captured in the Glory Hole. A moving average of the previous 30 days compared to the daily mean streamflow generally was most significant as a term to account for hysteresis in constituent transport at site 5 (table 7). Mean slope in the watershed upstream of each monitoring site was similar (37-38 percent) at sites 1-4, but was 50 percent at site 5 (U.S. Geological Survey, 2012). Each monitoring site, with the exception of site 5 , also showed a diurnal variation in streamflow during snowmelt runoff periods. A more detailed analysis of watershed characteristics that control sediment sources and transport is beyond the scope of this study.

\section{Surrogate Regression Modeling of Constituent Concentrations}

Results of surrogate regression modeling indicate the value of continuously measured specific conductance for estimating constituent concentrations. Specific conductance was used as a predictor variable in surrogate models developed to estimate concentrations of dissolved arsenic and antimony at all five monitoring sites (table 8). Continuous specific conductance was a more significant predictor than streamflow in four of five surrogate regression models for dissolved arsenic concentrations, and two of five surrogate regression models for dissolved antimony concentrations (table 8). Streamflow and specific conductance were both significant in models of dissolved arsenic and antimony concentrations at the remaining sites.

Unlike LOADEST regression models, which were used to estimate and evaluate constituent transport in the study area on annual time scales, surrogate regression models were developed for the purpose of using real-time data from monitoring sites to generate a 15-minute time-series record of estimated constituent concentrations. LOADEST models also output estimated daily concentrations in addition to loads, and estimated LOADEST concentrations were compared to estimated daily concentrations from surrogate regression models. Surrogate regression models generally explained more variability in measured arsenic and antimony concentrations than LOADEST models, but specific conductance was not used as a predictor variable in the LOADEST models (tables 7 and 8). Results of surrogate regression modeling show that continuous water-quality and streamflow data at each studyarea monitoring site can be used to estimate concentrations of dissolved arsenic and antimony in real time. Further, in conjunction with real-time streamflow data, the estimated concentrations can be used to calculate loads in real time. 
Specific conductance was not a significant predictor for estimating real-time concentrations of total mercury (table 8). Surrogate regression model results show that streamflow and the BFI calculated from the local minimum method of hydrograph separation (Lim and others, 2005) can be used to estimate concentrations and loads of total mercury in real time at sites 4 and 5 . Additional total mercury samples are necessary to develop regression estimates of total mercury concentrations and loads at the remaining study sites. Sample results for total mercury from site 5 (Sugar Creek) suggest that summer storms can generate high concentrations of mercury at moderate streamflow (fig. 17). Substantial variance in sample results for total mercury at site 5 resulted in a large root mean square error for the surrogate regression model estimating total mercury concentrations at site 5. Additional samples collected during summer storms would provide valuable information towards understanding how mercury is transported to streams in the Stibnite area and would help to calibrate models for estimating mercury concentration and loading.

Table 8. Regression coefficients and model diagnostics for surrogate models used to estimate concentrations of selected constituents at monitoring sites in the Stibnite mining area, central Idaho, 2012-14.

[Site names and locations are shown in table 1 and figure 1, respectively. Each regression model was calibrated using the available data collected at each station for water years $2012-14$. The regression equation is $\ln C=I+a(S C)+b(\ln S C)+c(Q)+d(\ln Q))+e[\sin (2 \pi T)]+f[\cos (2 \pi T)]+g(B F I)$, where $C$ is the constituent concentration, in micrograms per liter; I is the regression intercept; $Q$ is the centered streamflow, in cubic feet per second; sin $(2 \pi \mathrm{T})$ and $\cos (2 \pi \mathrm{T})$ are periodic time functions that describe seasonal variability; BFI is the term describing streamflow variability; ln is the natural logarithm transformation; and a, $b$, $c, d, e, f$, and $g$ are regression coefficients that remain constant over time. $R^{2}$ (coefficient of determination), represents the amount of variance explained by the model in percent. A bbreviations: BCF, bias correction factor; RMSE, root mean square error; -, no regression coefficient]

\begin{tabular}{|c|c|c|c|c|c|c|c|c|c|c|c|c|c|}
\hline \multirow{2}{*}{ Constituent } & \multicolumn{9}{|c|}{ Regression coefficient } & \multirow{2}{*}{ BCF } & \multirow{2}{*}{$\begin{array}{c}\text { RMSE } \\
\text { (percent) }\end{array}$} & \multirow{2}{*}{$\begin{array}{c}\text { Surrogate } \\
\text { concen- } \\
\text { tration } \\
\text { model } R^{2}\end{array}$} & \multirow{2}{*}{$\begin{array}{c}\text { LOADEST } \\
\text { concen- } \\
\text { tration } \\
\text { model } \mathbf{R}^{2}\end{array}$} \\
\hline & $\mathbf{N}$ & $I$ & $a$ & $\boldsymbol{b}$ & $c$ & $d$ & $\boldsymbol{e}$ & $f$ & $g$ & & & & \\
\hline \multicolumn{14}{|c|}{ Site 1} \\
\hline \multicolumn{14}{|c|}{ Site 2} \\
\hline Arsenic, dissolved & 21 & -0.758 & 0.014 & - & - & - & - & - & - & 1.004 & 9.65 & 87 & 89 \\
\hline Antimony, dissolved & 18 & 14.457 & - & 2.920 & - & 0.816 & 0.375 & 0.583 & - & 1.012 & 18.1 & 72 & 62 \\
\hline \multicolumn{14}{|c|}{ Site 3} \\
\hline Arsenic, dissolved & 21 & -3.072 & - & 1.561 & - & - & -0.044 & -0.180 & - & 1.007 & 13.6 & 95 & 72 \\
\hline Antimony, dissolved & 21 & -11.776 & - & 2.888 & - & 0.615 & 0.182 & 0.156 & - & 1.010 & 16.1 & 91 & 32 \\
\hline Mercury, total & 15 & -3.957 & - & - & 0.003 & - & - & - & -1.755 & 1.030 & 35.0 & 85 & 76 \\
\hline \multicolumn{14}{|c|}{ Site 5} \\
\hline Arsenic, dissolved & 21 & 1.407 & 0.011 & - & - & - & 0.119 & 0.274 & - & 1.013 & 18.2 & 86 & 77 \\
\hline Antimony, dissolved & 20 & -0.867 & 0.021 & - & - & - & 0.151 & 0.410 & - & 1.032 & 29.1 & 90 & 75 \\
\hline Mercury, total & 19 & 3.045 & - & - & 0.010 & - & -0.369 & -1.194 & -7.644 & 1.367 & 109 & 87 & 82 \\
\hline
\end{tabular}




\section{Areas of Further Study}

Additional samples collected on the rising and falling limbs of the streamflow hydrograph during summer storms would help validate all regression models presented in this report. Given the remote location of the study area and the flashiness of storm events, obtaining storm samples may require installation of auto-samplers. However, because concentrations of sediment and sediment-associated constituents may not be evenly distributed in the stream cross section, auto-samplers, which are point samplers, may not provide an adequate representation of stream concentrations. A continuous physical measure of sediment in the water column, or a surrogate such as turbidity, is not appropriate for the study area because most sediment transported is coarse ( $>0.0625 \mathrm{~mm}$ in diameter) and does not necessarily cause increases in turbidity. Acoustic backscatter may or may not be a significant predictor of sediment concentration at study-area sites and would require further investigation of feasibility. The steep gradient in the study area may contribute to bedload transport of coarse sediment and sediment-associated metals. Bedloads are not well characterized by surrogate measures of sediment concentrations in the water column.

MGI-directed sample collection at various surface-water sites within the study area in addition to the five USGS monitoring sites operated and sampled during this study. Measured discrete loads at additional sites in the study area could be compared to load estimates in the Meadow Creek reach and the Glory Hole reach that are summarized in this report. Such comparisons may identify more specific source areas and validate LOADEST modeling results.

Tracer-injection methods also can be used to validate findings in this report and to identify more specific sources of contaminants. Tracer injection in discrete reaches of interest (such as the Glory Hole reach) can provide reliable streamflow measurements on a watershed scale in addition to spatially detailed concentration information when combined with synoptic sampling. Streamflow and concentration data then can be used to develop mass-loading profiles for metals of interest. Streamflow and loading profiles identify the primary sources in spatial detail and demonstrate the importance of unsampled, dispersed subsurface inflows and attenuation (Kimball and others, 2004). Longitudinal loading profiles generated from tracer injection studies, therefore, are useful for targeting remediation efforts.

With continued operation of continuous stream stage and specific conductance sensors at monitoring sites, real time estimates of arsenic, antimony, and mercury concentrations can be made publicly available on the USGS National Water Information System (U.S. Geological Survey, 2015). Changes in land use associated with mining activities may be detected with subsequent evaluation of regression model coefficients and inclusion of a predictor variable that accounts for trends.

\section{Summary}

Water-quality and streamflow monitoring during 20122014 showed that concentrations of trace elements, except for mercury, generally do not exceed ambient water-quality criteria applicable in streams in the Stibnite mining area of central Idaho. Total mercury was detected at concentrations greater than the State of Idaho 0.012-microgram per liter $(\mu \mathrm{g} / \mathrm{L})$ chronic exposure limit for freshwater aquatic life at five monitoring sites used for the study. Arsenic and antimony concentrations exceeded human-health based water-quality criteria in Sugar Creek (site 5) and both monitoring sites located on the East Fork of the South Fork of the Salmon River (EFSFSR) downstream of the confluence with Meadow Creek. Arsenic concentrations exceeded the $10-\mu \mathrm{g} / \mathrm{L}$ humanhealth-based standard about one-half the time in the EFSFSR upstream of the confluence with Meadow Creek (site 1), but did not exceed $10 \mu \mathrm{g} / \mathrm{L}$ at Meadow Creek (site 2). Site 2 was selected to represent background conditions, and the median total arsenic concentration in samples collected from site 2 was $1.3 \mu \mathrm{g} / \mathrm{L}$. Water temperature exceeded the $9{ }^{\circ} \mathrm{C}$ maximum daily average temperature criterion for salmonid spawning at least 29 percent of the time at each site. Water temperature at sites 3 and 4 in the EFSFSR and site 5 in Sugar Creek exceeded the $13{ }^{\circ} \mathrm{C}$ maximum daily maximum temperature criterion for salmonid spawning between 4 and 9 percent of the time.

Two distinct constituent sources are present in the study area. Significant positive correlations between streamflow and concentrations of suspended sediment and sediment-associated constituents (total aluminum, total lead, and total mercury) indicate that surface runoff and stream-channel erosion deliver these constituents to streams during rainfall or snowmelt runoff. Significant negative correlations between streamflow and concentrations of arsenic, antimony, and dissolved iron and magnesium indicate that groundwater is the source for these constituents. Significant correlation between constituent concentrations and streamflow also showed that the U.S. Geological Survey LOAD ESTimation (LOADEST) program is a useful tool for estimating mean annual loads and streamflow-weighted concentrations (FWCs) of selected constituents in streams in the study area.

Mass balance estimates show that concentrated sources of arsenic, antimony, and dissolved manganese are present in discrete reaches along Meadow Creek and between sites 3 and 4 along the EFSFSR. Although they accounted for only 25 percent of the total streamflow, the reaches along Meadow Creek (the Meadow Creek reach) and between sites 3 and 4 (the Glory Hole reach) accounted for 80 percent of the total arsenic and antimony loads and 86 percent of the dissolved manganese load transported downstream of the study area. Estimated FWCs exceeded human-health based water-quality criteria for arsenic and antimony at sites 3 and 4 in the EFSFSR and for arsenic at site 5 in Sugar Creek. 
Continuously monitored specific conductance was statistically significant as a predictor (surrogate) for concentrations of dissolved arsenic and antimony at all study-area sites. Surrogate regression models using continuous stage and specific conductance, and, in some cases, functions of streamflow and time, can be used to estimate concentrations and loads of dissolved arsenic and antimony at all five study-area sites.

The East Fork of Meadow Creek was not monitored as part of this study, but LOADEST model results indicate that the East Fork Meadow Creek, the only tributary stream in the Meadow Creek reach, likely accounts for most of the suspended sediment loading in the study area. Sediment and sediment-associated constituent loads from the East Fork of Meadow Creek are trapped in the Glory Hole between sites 3 and 4. FWCs of suspended sediment, total aluminum, and total lead decrease in the Glory Hole reach between sites 3 and 4. The Meadow Creek reach was the largest contributor of suspended sediment and the second largest contributor of total aluminum in the study area. The East Fork Meadow Creek in the Meadow Creek reach was not sampled, but likely contributes most of the sediment and aluminum attributed to the Meadow Creek reach. Because sediment and sediment-associated constituents from sources upstream of the Glory Hole are trapped in the Glory Hole, Sugar Creek accounts for most of the sediment and sediment-associated constituent loading transported downstream of the study area. Sugar Creek (site 5) is the second largest contributor of suspended sediment and the largest contributor of total aluminum in the study area. Sugar Creek accounted for 98 percent of the total mercury load transported downstream of the study area.

LOADEST model results indicated hysteresis in transport of suspended sediment and sediment-associated constituents within the study area. Biases in estimated loads were reduced using an additional predictor variable to describe streamflow variability relative to an $n$-day average streamflow. The ratio of estimated surface runoff to streamflow, known as the base-flow index, was tested for significance as another predictor variable to account for streamflow variability. Different streamflow variability terms were significant as predictor variables in different sub-watersheds, indicating that watershed characteristics and (or) conditions preceding erosional events may influence sediment transport in the study area. Results from samples collected during a summer storm in August 2014 showed that LOADEST and surrogate regression models may not produce reliable estimates of sediment and sediment-associated constituent concentrations and loads during rainfall runoff events. Regression models using streamflow and the base-flow index as predictor variables accounted for at least 80 percent of the variability in sampled concentrations of total mercury at sites 4 (EFSFSR above Sugar Creek) and 5 (Sugar Creek). With continued operation of continuous stage sensors, concentrations and loads of total mercury can be estimated in real time at sites 4 and 5.
Additional sample results are necessary to evaluate LOADEST and surrogate models for total mercury concentrations and loads at remaining study area sites and during summer storms at sites 4 and 5 .

\section{Acknowledgments}

The author thanks Rhonda Weakland, Alvin Sablan, Pete Spatz, Russ Chirstensen, and Keith Hein for their dedication to collecting and processing water-quality samples, continuous water-quality data, and streamflow data at these remote sites under an extreme range of weather and streamflow conditions. Thanks also to members of the Boise Field Office and Idaho Falls Field Office for installation of bank-operated cableways at two of the monitoring sites in the study area.

\section{References Cited}

Akaike, Hirotugu, 1981, Likelihood of a model and information criteria: Journal of Econometrics, v. 16, no. 1, p. 3-14.

American Society for Testing and Materials, 2002, Standard test methods for determining sediment concentration in water samples-Method \#ASTM D3977-97: American Society for Testing and Materials, accessed March 2013, at http://www.astm.org/Standard/index.shtml.

Bradu, Dan, and Mundlak, Yair, 1970, Estimation in lognormal linear models: Journal of the American Statistical Association, v. 65, no. 329, p. 198-211.

Cohn, T.A., Caulder, D.L., Gilroy, E.J., Zynjuk, L.D., and Summers, R.M., 1992, The validity of a simple statistical model for estimating fluvial constituent loadsAn empirical study involving nutrient loads entering Chesapeake Bay: Water Resources Research, v. 28, no. 9, p. 2,353-2,363.

Cohn, T.A., Delong, L.L, Gilroy, E.J., Hirsch, R.M., and Wells, D.K., 1989, Estimating constituent loads: Water Resources Research, v. 25, no. 5, p. 937-942.

Crawford, C.G., 1991, Estimation of suspended-sediment rating curves and mean suspended-sediment loads: Journal of Hydrology, v. 129, p. 331-348.

DeCicco, L., and Corsi, S., 2014, The GSqwsr R packageWater-quality surrogate regressions, 25 p.

Fishman, J.J., ed., 1993, Methods of analysis by the U.S. Geological Survey National Water Quality LaboratoryDetermination of inorganic and organic constituents in water and fluvial sediments: U.S. Geological Survey Open-File Report 93-125, 217 p. 
Fishman, M.J., and Friedman, L.C., 1989, Methods for determination of inorganic substances in water and fluvial sediments: U.S. Geological Survey Techniques of WaterResources Investigations, book 5, chap. A1, 545 p.

Garbarino, J.R., and Damrau, D.L., 2001, Methods of analysis by the U.S. Geological Survey National Water Quality Laboratory-Determination of organic plus inorganic mercury in filtered and unfiltered natural water with cold vapor-atomic fluorescence spectrometry: U.S. Geological Survey Water-Resources Investigations Report 2001-4132, $16 \mathrm{p}$.

Garbarino, J.R., Kanagy, L.K., and Cree, M.E., 2005, Determination of elements in natural-water, biota, sediment and soil samples using collision/reaction cell inductively coupled plasma-mass spectrometry: U.S. Geological Survey Techniques and Methods, book 5, sec. B, chap. 1, 88 p.

Garbarino, J.R., Kanagy, L.K., and Cree, M.E., 2006, Determination of elements in natural-water, biota, sediment and soil samples using collision/reaction cell inductively coupled plasma-mass spectrometry: U.S. Geological Survey Techniques and Methods, book 5, sec. B, chap. 1, 88 p.

Garbarino, J.R., and Struzeski, T.M., 1998, Methods of analysis by the U.S. Geological Survey National Water Quality Laboratory-Determination of elements in wholewater digests using inductively coupled plasma-optical emission spectrometry and inductively coupled plasmamass spectrometry: U.S. Geological Survey Open-File Report 98-165, 101 p.

Garrett, J.D., 2012, Concentrations, loads, and yields of select constituents from major tributaries of the Mississippi and Missouri Rivers in Iowa, water years 2004-2008: U.S. Geological Survey Scientific Investigations Report 2012-5240, 61 p.

Gilroy, E.J., Hirsch, R.M., and Cohn, T.A., 1990, Mean square error of regression-based constituent transport estimates: Water Resources Research, v. 26, p. 2069-2088.

Goolsby, D.A., Battaglin, W.A., Lawrence, G.B., Artz, R.S., Aulenbach, B.T., Hooper, R.P., Keeney, D.R., and Stensland, G.J., 1999, Flux and sources of nutrients in the Mississippi-Atchafalaya River Basin-Topic 3 report for the integrated assessment on hypoxia in the Gulf of Mexico: Silver Spring, Md., National Oceanic and Atmospheric Administration Coastal Ocean Program Decision Analysis Series No. 17, 130 p.

Gustard, A., and Demuth, S., 2009, Manual on lowflow estimation and prediction: World Meteorological Organization, Operational Hydrology Report No. 50, WMO-No. 1029, 136 p.
Guy, H.P., 1969, Laboratory theory and methods for sediment analysis: U.S. Geological Survey Techniques of Water Resources Investigations, book 5, chap. C1, 58 p., accessed September 29, 2015, at http://pubs.usgs.gov/twri/twri5c1/.

Helsel, D.R., 2012. Statistics for censored environmental data using Minitab and R (2d ed.): New York, Wiley, 344 p.

Helsel, D.R., and Hirsch, R.M., 2002, Statistical methods in water resources: U.S. Geological Survey Techniques of Water-Resources Investigations, book 4, chap. A3, 510 p., accessed September 29, 2015, at http://pubs.usgs.gov/twri/ twri4a3/.

Hirsch, R.M., 2014, Large biases in regression-based constituent flux estimates-Causes and diagnostic tools: Journal of the American Water Resources Association, v. 50, no. 6, p. 1,401-1,424, doi: 10.1111/jawr.12195.

Hoffman, G.L., Fishman, M.J., and Garbarino, J.R., 1996, Methods of analysis by the U.S. Geological Survey National Water Quality Laboratory-In-bottle acid digestion of whole-water samples: U.S. Geological Survey Open-File Report 96-225, 28 p.

Idaho Department of Environmental Quality, 2002, South Fork Salmon River subbasin assessment: Boise, Idaho Department of Environmental Quality, 127 p.

Idaho Department of Environmental Quality, 2012, South Fork Salmon River subbasin temperature total maximum daily loads and revised sediment targets-Addendum to the SF Salmon River subbasin assessment and TMDL: Idaho Department of Environmental Quality, 130 p., accessed March 24, 2015, at http://www.deq.idaho.gov/ media/809319-south-fork-salmon-river-temperature-tmdlsaddendum-0912.pdf.

Idaho Department of Environmental Quality, 2014, Idaho’s 2012 integrated report: Idaho Department of Environmental Quality, 847 p., accessed January 16, 2015, at https://www. deq.idaho.gov/media/1117323/integrated-report-2012-finalentire.pdf.

Idaho Department of Environmental Quality [various dates], IDAPA 58.01.02 - Water quality standards, Title 1, Chapter 2: Idaho Department of Environmental Quality, 180 p., accessed February 5, 2015, at http://adminrules. idaho.gov/rules/current/58/index.html.

Judge, C.G., Griffiths, W.E., Hill, R.C., Lutkepohl, H., and Lee, T.C., 1985, The theory and practice of econometrics: New York, Wiley, p. 870-873. 
Kimball, B.A., Runkel, R.L., Cleasby, T.E., and Nimick, D.A., 2004, Quantification of metal loading by tracer injection and synoptic sampling, 1997-98, chap. D6 of Nimick, D.A., Church, S.E., and Finger, S.E., eds., Integrated investigations of environmental effects of historical mining in the Basin and Boulder Mining Districts, Boulder River watershed, Jefferson County, Montana: U.S. Geological Survey Professional Paper 1652, p. 191-262.

Klahr, P.C., 1987, Water quality trend monitoring from 1979 1985 in the Stibnite mining district, Valley County, Idaho: Boise, Idaho Department of Health and Welfare, Division of Environment Water Quality Status Report No. 70, 52 p.

Knott, J.M., Glysson, G.D., Malo, B.A., and Schroeder, L.J., 1993, Quality assurance plan for the collection and processing of sediment data by the U.S. Geological Survey, Water Resources Division: U.S. Geological Survey OpenFile Report 92-499, 18 p.

Kuzis, K, 1997, Watershed analysis of the upper East Fork South Fork Salmon River, volumes 1 and 2: Report of KK Consulting to U.S. Forest Service, McCall, Idaho.

Landers, M.N., and Sturm, T.W., 2013, Hysteresis in suspended sediment to turbidity relations due to changing particle size distributions: Water Resources Research, v. 49, p. 5,487-5,500, doi: 10.1002/wrcr.20394.

Larsen, E.S, and Livingston, D.C., 1920, Contributions to economic geology, 1920, Part 1, Metals and nonmetals except fuels - Geology of the Yellow Pine cinnabar-mining district, Idaho: U.S. Geological Survey Bulletin 715-E, p. 73-83.

Lim, K.J., Engel, B.A., Tang, Z., Choi, J., Kim, K., Muthukrishnan, S., and Tripathy, D., 2005, Automated web GIS based hydrograph analysis tool, WHAT: Journal of the American Water Resources Association, v. 41, no. 6, p. 1,407-1,416, accessed September 29, 2015, at https:// engineering.purdue.edu/ what/faq/Automated_Web_GIS_ based_Hydrograph_Analysis_Tool_WHAT_JAWRA_ Dec_2005.pdf.

Mebane, C.A., 2006, Cadmium risks to freshwater lifeDerivation and validation of low-effect criteria values using laboratory and field studies: U.S. Geological Survey Scientific Investigations Report 2006-5245 (2010 rev.), 130 p., accessed September 29, 2015, at http://pubs.usgs. gov/sir/2006/5245/.

Mitchell, V.E., 2000, History of the Stibnite mining area, Valley County, Idaho: Idaho Geological Survey Staff Report 00-3, 166 p., accessed January 15, 2015, at http://www. idahogeology.org/PDF/Staff_Reports_(S)/2000/SR-00-3V1. pdf.
Moyer, D.L., Hirsch, R.M., and Hyer, K.E., 2012, Comparison of two regression-based approaches for determining nutrient and sediment fluxes and trends in the Chesapeake Bay watershed: U.S. Geological Survey Scientific Investigations Report 2012-5244, 118 p., accessed September 29, 2015, at http://pubs.usgs.gov/sir/2012/5244.

Mueller, D.S., and Wagner, C.R., 2009, Measuring discharge with acoustic Doppler current profilers from a moving boat: U.S. Geological Survey Techniques and Methods, book 3, chap. A22, 72 p., accessed September 29, 2015, at http:// pubs.water.usgs.gov/tm3a22.

Oblinger Childress, C.J., Foreman, W.T., Connor, B.F, and Maloney, T.J.,1999, New reporting procedures based on long-Term method detection levels and some considerations for interpretations of water-quality data provided by the U.S. Geological Survey National Water Quality Laboratory: U.S. Geological Survey Open-File Report 99-193, 19 p., accessed September 29, 2015, at http://water.usgs.gov/owq/ OFR_99-193/ofr99_193.pdf.

Pritt, J.W., and Raese, J.W., eds., 1995, Quality assurance/ quality control manual-National Water Quality Laboratory: U.S. Geological Survey Open-File Report 95-443, 35 p.

Rantz, S.E., and others, 1982, Measurement and computation of streamflow: U.S. Geological Survey Water-Supply Paper 2175, v. 2, 631 p., accessed September 29, 2015, at http:// pubs.usgs.gov/wsp/wsp2175/html/wsp2175_vol2.html.

Rea, Alan, and Skinner, K.D., 2009, Estimated perennial streams of Idaho and related geospatial datasets: U.S. Geological Survey Data Series 412, 32 p.

Runkel, R.L., 2013, Revisions to LOADEST, April 2013: U.S. Geological Survey, LOADEST Update, 6 p., accessed September 29, 2015, at http://water.usgs.gov/software/ loadest/doc/loadest_update.pdf.

Runkel, R.L., Crawford, C.G., and Cohn, T.A., 2004, Load Estimator (LOADEST) - A FORTRAN program for estimating constituent loads in streams and rivers: U.S. Geological Survey Techniques and Methods, book 4, chap. A5, 69 p., accessed September 29, 2015, at http:// pubs.usgs.gov/tm/2005/tm4A5/.

Stenback, G.A., Crumpton, W.G., Schilling, K.E., and Helmers, M.J., 2011, Rating curve estimation of nutrient loads in Iowa rivers: Journal of Hydrology, v. 396, p. 158-169, doi: 10.1016/j.jhydrol. 2010.11.006.

Trainor, P. 1993, Preliminary assessment/site investigationStibnite Mining Area: U.S. Forest Service, Payette National Forest, CERLIS ID. NO. ID9122307607. 
Trainor, P., 2003, Removal report-North tailings impoundment Cinnabar Mine Yellow Pine, Idaho: U.S. Forest Service, Payette National Forest, McCall, Idaho, $55 \mathrm{p}$.

Turnipseed, D.P., and Sauer, V.B., 2010, Discharge measurements at gaging stations: U.S. Geological Survey Techniques and Methods, book 3, chap. A8, 87 p., accessed September 29, 2015, at http://pubs.usgs.gov/tm/tm3-a8/.

URS Corporation, 2000, Stibnite area site characterization report, volume I, sections 1-11, September 8, 2000: URS Corporation, $113 \mathrm{p}$.

U.S. Environmental Protection Agency, 2002, National recommended water quality criteria-2002: U.S. Environmental Protection Agency, EPA-822-R-02-047, $36 \mathrm{p}$.

U.S. Forest Service, 2012, Chaps. 1 and 2 of Environmental assessment, Golden Meadows Exploration Project: U.S. Forest Service, $92 \mathrm{p}$.

U.S. Geological Survey, 2012, The StreamStats program for Idaho: U.S. Geological Survey Web site, accessed September 29, 2015, at http://water.usgs.gov/osw/ streamstats/idaho.html.

U.S. Geological Survey, 2015, USGS water data for the Nation: U.S. Geological Survey database, accessed September 17, 2015, at http://waterdata.usgs.gov/id/ nwis/inventory?chk_all=on\&site_no $=13310800 \&$ site no $=13310850 \&$ site_no $=13311000 \&$ site no=13311250\&site_no=13311450\&group_ key $=$ NONE\&sitefile_output_format $=$ html_table\&column name=agency_cd\&column_name=site_no\&column_ name=station_nm\&format=station_manuscript\&submitted_ form=scroll_list.
U.S. Geological Survey [various dates], National field manual for the collection of water-quality data: U.S. Geological Survey Techniques of Water-Resources Investigations, book 9, chaps. A1-A9, accessed September 29, 2015, at http://pubs.water.usgs.gov/twri9A.

Wagner, R.J., Boulger, R.W., Jr., Oblinger, C.J., and Smith, B.A., 2006, Guidelines and standard procedures for continuous water-quality monitors-Station operation, record computation, and data reporting: U.S. Geological Survey Techniques and Methods, book 1, chap. D3, 51 p. plus 8 attachments, accessed September 29, 2015, at http:// pubs.water.usgs.gov/tm1d3.

Wang, Ping, and Linker, L.C., 2008, Improvement of regression simulation in fluvial sediment loads: Journal of Hydraulic Engineering, v. 134, no. 10, p. 1,527-1,531.

Wang, Y., Kuhnert, P., Henderson, B., 2010, Load estimation with uncertainties from opportunistic sampling data-A semiparametric approach: Journal of Hydrology, v. 396, p. 148-157, http://dx.doi.org/10.1016/j.jhydrol.2010.11.003.

Weiner, E.R, 2012, Applications of environmental aquatic chemistry - A practical guide ( $3 \mathrm{~d}$ ed.): Boca Raton, Fla., CRC Press, $618 \mathrm{p}$

Wood, M.S., and Etheridge, A.B., 2011, Water-quality conditions near the confluence of the Snake and Boise Rivers, Canyon County, Idaho: U.S. Geological Survey Scientific Investigations Report 2011-5217, 70 p.

Woodworth, M.T., and Connor, B.F., 2003, Results of the U.S. Geological Survey's analytical evaluation program for standard reference samples distributed in March 2003: U.S. Geological Survey Open-File Report 2003-261, 109 p. 
This page left intentionally blank 


\section{Appendix A. Analysis of Quality-Assurance and Quality-Control Data from Field Samples in Streams in the Stibnite Mining Area, Central Idaho, and Laboratory Samples from the National Water-Quality Laboratory, 2012-14}

Results from the National Water Quality Laboratory's (NWQL) inorganic blind sampling project (IBSP) showed a positive bias for dissolved analyses of cadmium and lead. Wilcoxon signed-rank tests were used to assess bias relative to the median expected concentration in the reference sample (Woodworth and Connor, 2003; T. Struzenski, U.S. Geological Survey, written commun., 2013). Positive biases in dissolved cadmium and lead results were known to occur starting in October 2011 and January 2012, respectively, and were corrected by the end of water year 2013. Positive bias in dissolved cadmium results ranged from 13 to less than 6 percent, and positive bias in dissolved lead results ranged from 7.4 to 5.8 percent (T. Struzenski, U.S. Geological Survey, written commun., 2013).

Positive bias in dissolved concentrations of cadmium and lead affected the quality of analytical results. Uncensored dissolved concentrations were greater than whole-water concentrations in 86 percent of cadmium results and 24 percent of lead results (table A1). Consistent positive or negative bias in dissolved or whole-water results for zinc, copper, antimony, and arsenic was not documented. However, dissolved concentrations of zinc, copper, antimony, and arsenic also commonly exceeded concentrations from whole-water samples (table A1. Dissolved antimony concentrations that were commonly higher than total antimony concentrations resulted in model results with larger loads and streamflow-weighted concentrations for dissolved antimony than total antimony in some cases. However, this did not affect the interpretive results in the report because analytical data indicate that most of the antimony on site is dissolved. Numerous dissolved results were flagged in the National Water Information System (NWIS) database based on:

1. The known positive bias shown in IBSP analytical results for dissolved cadmium and lead,

2. The relative percent difference (RPD) between uncensored dissolved concentrations and censored or uncensored whole-water concentrations, and

3. The 2014 long-term method detection level (LT-MDL) for the dissolved constituent. The LT-MDL is determined based on the standard deviation of a minimum of 24 method-detection-limit spike sample measurements over an extended period of time (Oblinger Childress and others, 1999).
The NWQL collects quality-control data on a continuous basis to assess variations in LT-MDLs and to determine or revise LT-MDLs from year to year. Several LT-MDLs changed during the study period (table A1). Dissolved concentrations were flagged as "estimated" in the NWIS database if they were reported as uncensored at a concentration lower than the latest LT-MDL regardless of the RPD compared to the whole-water concentration in the same sample. Uncensored dissolved constituents detected at higher concentrations than whole-water constituents were flagged as "reviewed and rejected" in the NWIS database if the RPD compared to the censored or uncensored whole-water concentration in the same sample was greater than 20 percent. In most of these cases, repeated laboratory analysis for dissolved and total constituents confirmed original results. Analysis of the quality-control dataset collected for this study includes rejected results, but they are not otherwise used, interpreted, or provided to the public. Estimated results are used, interpreted, and provided to the public.

During water years 2012-14, 11 split replicate samples were collected on a rotating basis between the five study sites. Split-replicate RPDs greater than 20 percent for individual sets of samples generally occurred with rarely detected trace elements or trace elements detected near the applicable LT-MDL. Relatively large RPDs also occurred with concentrations of total iron, total aluminum, and suspended sediment in split-replicates collected at site 3 near the peak runoff event in May 2012 (table A2).

Results from the field blanks indicate overall acceptable quality (table A2). Four field blanks collected between May 17 and June 23, 2012, contained 29 out of a total of 41 detections (table A3). Field equipment cleaning practices between May and June of 2012 may have been ineffective in removing residual contamination, which may have resulted in positive bias to sample results, but other sources of bias also were present during the period. Forty-eight percent of the field blank detections between May and June 2012 were associated with cadmium, lead, and manganese. Positive laboratory bias in dissolved cadmium and lead was confirmed in laboratory quality-assurance testing (T. Struzenski, U.S. Geological Survey, written commun., 2013). Eight detections of dissolved manganese out of 15 blanks probably resulted from bias introduced during filtration (S. Skrobialowski, U.S. Geological Survey, written commun., 2015). 
Table A1. Quality-assurance summary for selected constituent analyses from streams in the Stibnite mining area, central Idaho, 2012-14.

[A bbreviations: QA, quality assurance; QC quality control; RPD, relative percent difference; >, greater than; $\mu \mathrm{g} / \mathrm{L}$, micrograms per liter; NWIS, National Water Information System; LT-MDL, long-term method detection limit. Dissolved concentrations are determined from filtered samples and whole-water concentrations are determined from unfiltered samples]

\begin{tabular}{|c|c|c|c|c|c|c|}
\hline & Cadmium & Copper & Lead & Zinc & Antimony & Arsenic \\
\hline $\begin{array}{l}\text { Number of environmental samples (including split replicate } \\
\text { QA/QC samples) }\end{array}$ & 118 & 115 & 118 & 118 & 115 & 118 \\
\hline Number of uncensored dissloved results & 36 & 17 & 68 & 11 & 115 & 118 \\
\hline $\begin{array}{l}\text { Number of uncensored dissolved concentrations > whole-water } \\
\text { concentrations (censored or uncensored) }\end{array}$ & 31 & 8 & 16 & 4 & 64 & 32 \\
\hline $\begin{array}{l}\text { Percentage of uncensored dissolved concentrations }>\text { whole-water } \\
\text { concentrations (censored or uncensored) }\end{array}$ & 86 & 47 & 24 & 36 & 56 & 27 \\
\hline $\begin{array}{l}\text { Average RPD between uncensored dissolved concentrations } \\
\text { > whole-water concentrations (censored or uncensored) }\end{array}$ & 91.1 & 42.3 & 32.9 & 63.2 & 8.15 & 5.58 \\
\hline $\begin{array}{l}\text { Number of dissolved results flagged as "rejected" in the NWIS } \\
\text { database }\end{array}$ & 22 & 6 & 10 & 0 & 3 & 0 \\
\hline $\begin{array}{l}\text { Long-term method detection limit October 1, } 2011 \text { to September 30, } \\
\text { 2013, } \mu \mathrm{g} / \mathrm{L} \text { (dissolved; whole-water) }\end{array}$ & $\begin{array}{l}0.016 \\
0.016\end{array}$ & $\begin{array}{l}0.80 \\
0.70\end{array}$ & $\begin{array}{c}0.025 \\
0.04\end{array}$ & $\begin{array}{l}1.4 \\
3.0\end{array}$ & $\begin{array}{c}0.027 \\
0.18\end{array}$ & $\begin{array}{l}{ }^{1} 0.04 \\
0.28\end{array}$ \\
\hline $\begin{array}{l}\text { Long-term method detection limit as of October 1, 2013, } \mu \mathrm{g} / \mathrm{L} \\
\text { (dissolved; whole-water) }\end{array}$ & $\begin{array}{l}0.03 \\
0.03\end{array}$ & $\begin{array}{l}0.80 \\
0.80\end{array}$ & $\begin{array}{l}0.04 \\
0.04\end{array}$ & $\begin{array}{l}2.0 \\
2.0\end{array}$ & $\begin{array}{c}0.027 \\
0.18\end{array}$ & $\begin{array}{l}0.10 \\
0.20\end{array}$ \\
\hline $\begin{array}{l}\text { Number of dissolved results flagged as "estimated" because of } \\
\text { increased LT-MDL }\end{array}$ & 6 & 0 & 0 & 0 & 0 & 0 \\
\hline
\end{tabular}

${ }^{1}$ The LT-MDL for dissolved arsenic was $0.03 \mu \mathrm{g} / \mathrm{L}$ from October 1, 2011 to September 30, 2012 and increased to $0.04 \mu \mathrm{g} / \mathrm{L}$ until September $30,2013$.

Blank sample detections did not indicate consistent positive bias from sampling equipment cleaning procedures or ambient conditions during sample processing, but did indicate occasional contamination bias from the source blank solution, shipping, storing, or analytical procedures. Blank detections that exceeded the minimum detections in environmental samples from the same trip are further summarized in table A3. In some cases, the blank detection exceeded the maximum detected concentration in environmental samples collected during the same trip, ruling out contamination bias from ambient processing conditions or equipment. In other cases, the dissolved constituent was detected and the total constituent was not detected in the same blank sample, suggesting positive bias in analytical procedures for the dissolved constituent. One detection each of dissolved cadmium, total lead, and total aluminum were within the range of detections for the same analyte during the same sampling trip, suggesting possible field equipment contamination.

Overall, split replicate, field blank, and IBSP quality-assurance sample results indicate that detections of dissolved cadmium and lead in environmental sample results should be used with caution. Blank results also suggest possible positive laboratory bias in dissolved chromium during May 2012. Manganese concentrations in environmental samples collected with potentially contaminated capsule filters were compared with environmental samples collected at similar streamflows at each site using uncontaminated capsule filters. The comparison showed that dissolved manganese introduced during sample filtration and quantified in blank results did not consistently bias environmental sample results for dissolved manganese. 


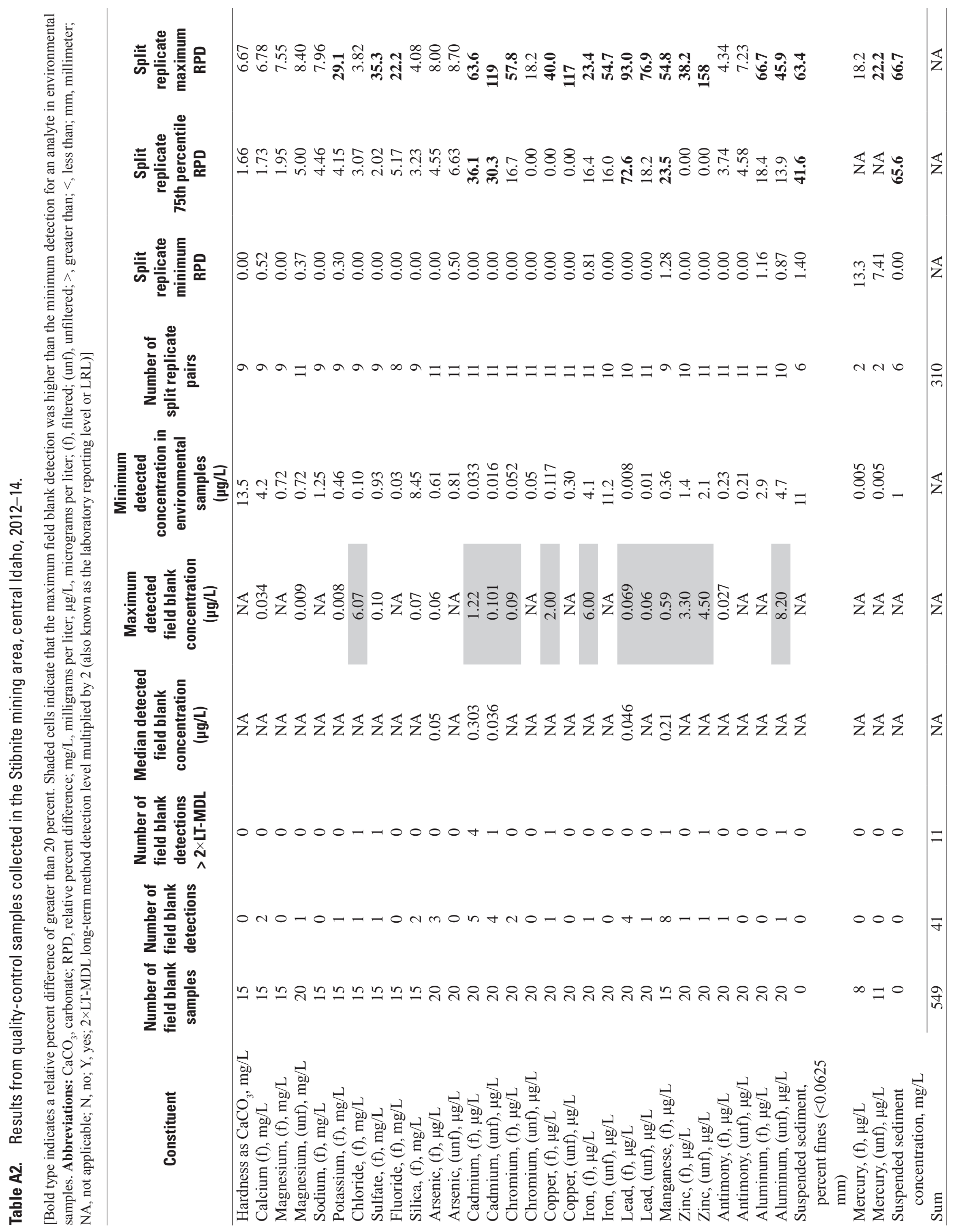


Table A3. Blank sample detections exceeding minimum detections in environmental samples collected in the Stibnite mining area, central Idaho, 2012-14.

[L ikely source of contamination: Handling, likely contamination bias from any of the following sources—source blank solution, shipping, storing, or analytical procedures; Equipment, contamination bias from sampling equipment; Filter, likely contamination bias from a capsule filter. Abbreviations: $\mathrm{mg} / \mathrm{L}$, milligrams per liter; $\mu \mathrm{g} / \mathrm{L}$, micrograms per liter; (f), filtered; (unf), unfiltered; $<$, less than; NA, not applicable]

\begin{tabular}{|c|c|c|c|c|c|}
\hline Constituent & $\begin{array}{c}\text { Blank } \\
\text { detection date }\end{array}$ & Blank & $\begin{array}{l}\text { Detected in } \\
\text { dissolved and } \\
\text { total results? }\end{array}$ & $\begin{array}{l}\text { Environmental } \\
\text { range during } \\
\text { sampling event }\end{array}$ & $\begin{array}{l}\text { Likely source of } \\
\text { contamination }\end{array}$ \\
\hline Chloride (f), mg/L & $05-23-12$ & 6.07 & NA & $0.23-0.38$ & Handling \\
\hline Aluminum (unf), $\mu \mathrm{g} / \mathrm{L}$ & 06-13-12 & 8.2 & No & 58.2-199 & Equipment \\
\hline Cadmium (f), $\mu \mathrm{g} / \mathrm{L}$ & $05-17-12$ & 0.434 & Yes & $0.088-0.371$ & Handling \\
\hline Cadmium (f), $\mu \mathrm{g} / \mathrm{L}$ & $05-18-12$ & 1.22 & Yes & $0.088-0.371$ & Handling \\
\hline Cadmium (f), $\mu \mathrm{g} / \mathrm{L}$ & $05-23-12$ & 0.251 & Yes & $0.088-0.371$ & Handling \\
\hline Cadmium (f), $\mu \mathrm{g} / \mathrm{L}$ & $11-06-12$ & 0.017 & No & $<0.016-0.056$ & Handling \\
\hline Cadmium (f), $\mu \mathrm{g} / \mathrm{L}$ & $10-01-14$ & 0.303 & No & $<0.030-0.194$ & Handling \\
\hline Cadmium (unf), $\mu \mathrm{g} / \mathrm{L}$ & $05-17-12$ & 0.025 & Yes & 0.017-0.037 & Equipment \\
\hline Cadmium (unf), $\mu \mathrm{g} / \mathrm{L}$ & 05-18-12 & 0.046 & Yes & $0.017-0.037$ & Handling \\
\hline Cadmium (unf), $\mu \mathrm{g} / \mathrm{L}$ & 05-23-12 & 0.101 & Yes & 0.017-0.037 & Handling \\
\hline Cadmium (unf), $\mu \mathrm{g} / \mathrm{L}$ & 06-13-12 & 0.021 & No & $<0.016-0.156$ & Handling \\
\hline Chromium (f), $\mu \mathrm{g} / \mathrm{L}$ & $05-17-12$ & 0.09 & No & $0.17-0.36$ & Handling \\
\hline Chromium (f), $\mu \mathrm{g} / \mathrm{L}$ & 05-18-12 & 0.09 & No & $0.17-0.36$ & Handling \\
\hline Copper (f), $\mu \mathrm{g} / \mathrm{L}$ & $05-23-12$ & 2.00 & No & $<0.80$ & Handling \\
\hline Iron (f), $\mu \mathrm{g} / \mathrm{L}$ & $05-23-12$ & 6.00 & No & 18.0-33.6 & Handling \\
\hline Lead (f), $\mu \mathrm{g} / \mathrm{L}$ & 05-18-12 & 0.029 & No & $0.027-0.063$ & Handling \\
\hline Lead (f), $\mu \mathrm{g} / \mathrm{L}$ & $05-23-12$ & 0.069 & No & $0.027-0.063$ & Handling \\
\hline Lead (f), $\mu \mathrm{g} / \mathrm{L}$ & 06-14-12 & 0.027 & No & 0.027-0.105 & Handling \\
\hline Lead (f), $\mu \mathrm{g} / \mathrm{L}$ & 05-19-14 & 0.062 & No & $<0.040-0.048$ & Handling \\
\hline Lead (unf), $\mu \mathrm{g} / \mathrm{L}$ & 06-13-12 & 0.06 & No & $0.04-0.10$ & Equipment \\
\hline Manganese (f), $\mu \mathrm{g} / \mathrm{L}$ & $05-17-12$ & 0.38 & NA & $1.16-6.29$ & Filter \\
\hline Manganese (f), $\mu g / L$ & 05-18-12 & 0.59 & NA & $1.16-6.29$ & Filter \\
\hline Manganese (f), $\mu g / L$ & $05-23-12$ & 0.17 & NA & $1.16-6.29$ & Filter \\
\hline Manganese (f), $\mu \mathrm{g} / \mathrm{L}$ & 06-13-12 & 0.14 & NA & $1.28-9.08$ & Filter \\
\hline Manganese (f), $\mu g / L$ & $11-06-12$ & 0.17 & NA & $0.57-37.5$ & Filter \\
\hline Manganese (f), $\mu g / L$ & 03-26-13 & 0.25 & NA & $1.56-28.8$ & Filter \\
\hline Manganese (f), $\mu \mathrm{g} / \mathrm{L}$ & $06-25-13$ & 0.17 & NA & $0.83-18.5$ & Filter \\
\hline Manganese (f), $\mu \mathrm{g} / \mathrm{L}$ & $04-25-14$ & 0.29 & NA & $0.77-20.5$ & Filter \\
\hline Zinc (f), $\mu \mathrm{g} / \mathrm{L}$ & $05-23-12$ & 3.3 & No & $<1.4-1.5$ & Handling \\
\hline Zinc (unf), $\mu \mathrm{g} / \mathrm{L}$ & 08-28-12 & 4.5 & No & $<3.0$ & Handling \\
\hline
\end{tabular}




\section{Appendix B. Statistical Summary of Constituent Concentrations in Water-Quality Samples Collected at Streamflow-Gaging Stations in the Stibnite Mining Area, Central Idaho, 2012-14}

Appendix B is a Microsoft Excel ${ }^{\circledR}$ file and is available for download at http://dx.doi.org/10.3133/sir20155166. 
Publishing support provided by the U.S. Geological Survey Science Publishing Network, Tacoma Publishing Service Center

For more information concerning the research in this report, contact the Director, Idaho Water Science Center

U.S. Geological Survey

230 Collins Road

Boise, Idaho 83702

http://id.water.usgs.gov 
